\title{
أثر هيمنة الثقافة الأمريكية ومـوقف المثقف العراقي منها \\ بحث اجتماعي ميداني في مدينة الديوانية
}

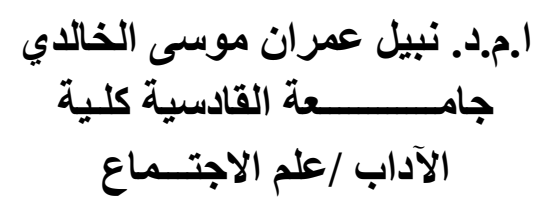

Summary: The globalization of the most important domination mechanisms designed to promote opening-up policy in the world, if we look at the reality in which they live and we found that there are internal factors within the countries has led to the American hegemony on them, and also there are external factors that led to that hegemony, and special mention here cultural hegemony that those interested in the study. In order to provide an understanding of the problem Find researcher believes should be brought to the study by asking the president of the following: What is the position of the intellectual hegemony of the American cultural model in social life, whether that negative or positive influence and roles exercised by in the face of that culture expatriate? The study aims to identify the roles that need to be educated on the Iraqi taken to counter American hegemony and position them. And deliberately intentional researcher to choose where the sample was chosen by the researcher on the sample of intellectuals (activists), as it was focused on cases which are classified among the intellectual elite, specifically of the population of the city of Diwaniya it has been determined a sample size (300 people). To achieve the objectives of the research study was limited to the survey tool (questionnaire), in the collection of facts and data. The study found that the group conclusions, including the American hegemony on the Arab countries, the risk of multiple aspects of a variety of forms, as covet riches Arab American policy, especially oil, and the employment of Arab strategic site home base for global objectives. The most important form of 
American hegemony over Iraq are military dominance, or military intervention, as a result of the invasion of Iraq from the US side has led to the exploitation of its wealth, make the Arab world advanced a base in their attempts to direct the dominance of military, economic and political.

Among the most important recommendations on the proposed Iraqi intellectuals working to unify their intellectual, cultural, and through trade unions and professions to which they belong, and to agree on specific points clearly show the field of cultural and political activity. And cooperation with the economic powers in the world to achieve collective economic interests for the establishment of a regional bloc in the interests of the Arab political, economic, cultural and other and makes them a unified force capable of communication with other world powers from the strong Muqtadir site.

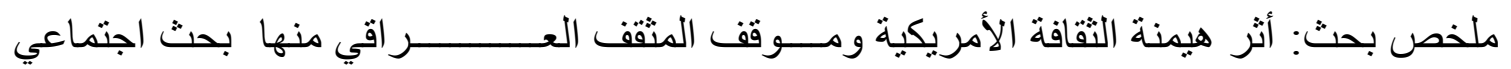
ميداني في مدينة الديو انية

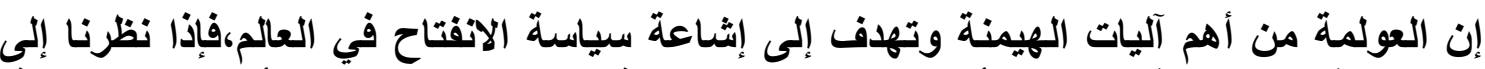

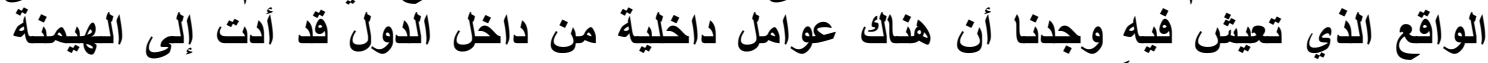

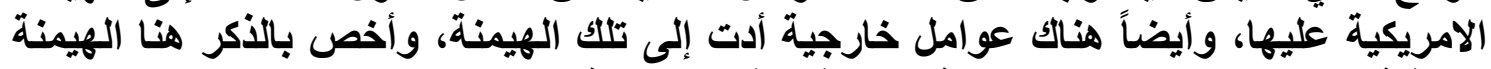

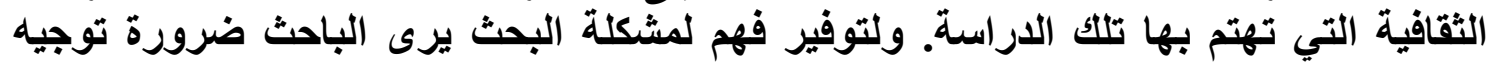

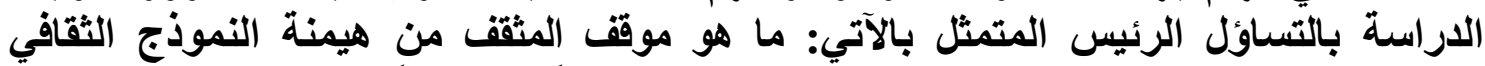

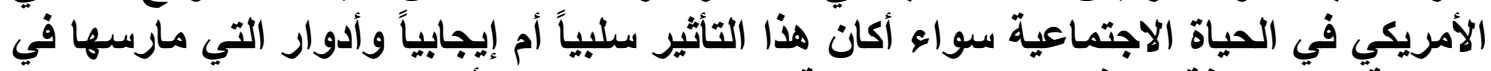

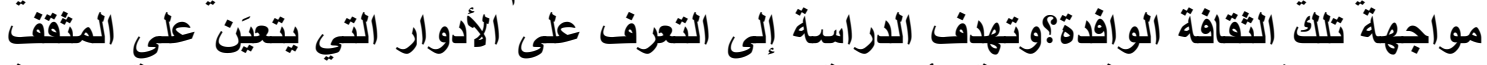

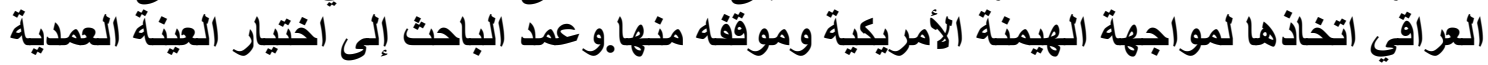

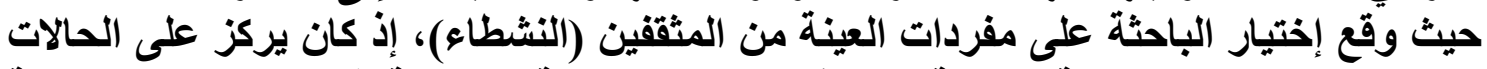

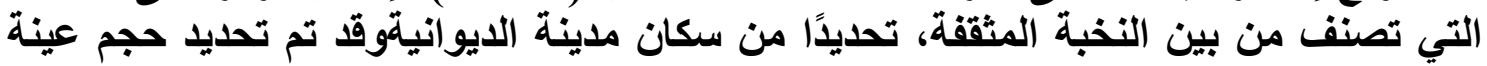

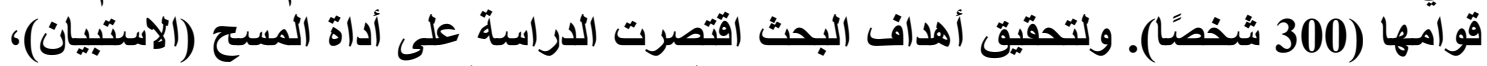

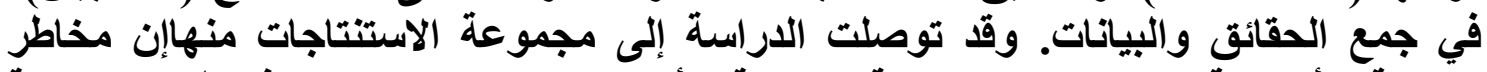

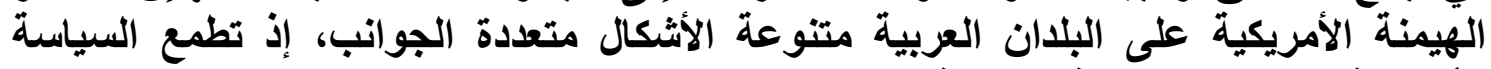

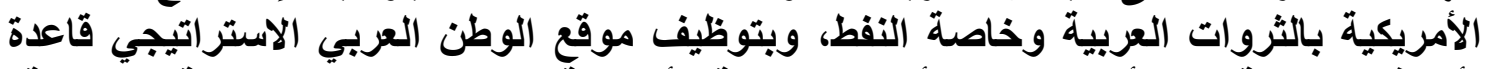

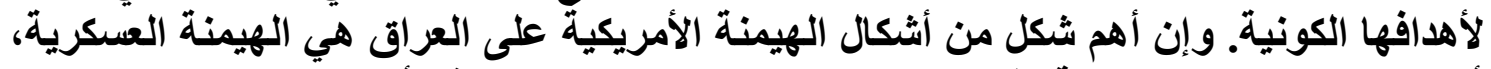

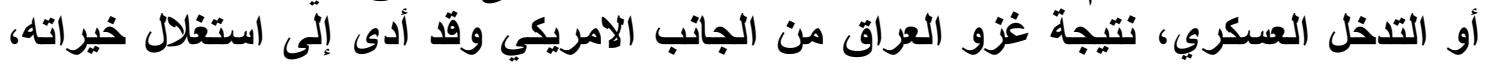


وجعل الوطن العربي قاعدة متقدمة لها في محاولاتها للهيمنة المباشرة العكرية والاقتصادية والسياسية.

ومن أهم التوصيات المقترحة على المثقفين العر اقيين العمل على توحيد جهودهم الفكرية، والثقافية

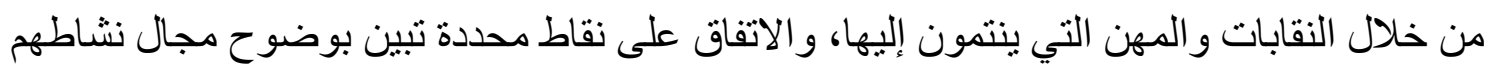

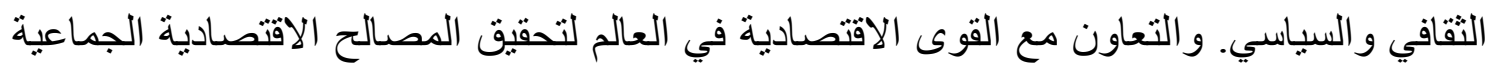

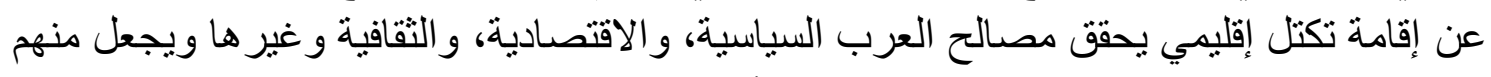
قوة موحدة قادرة على التخاطب مع قوى العالم الأخرى من موقع القوي المقتدر

\section{المقدمة}

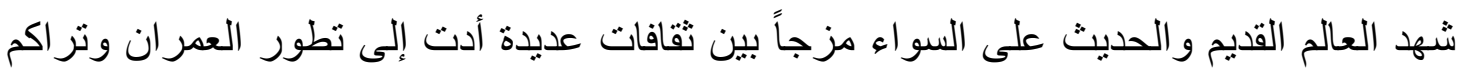

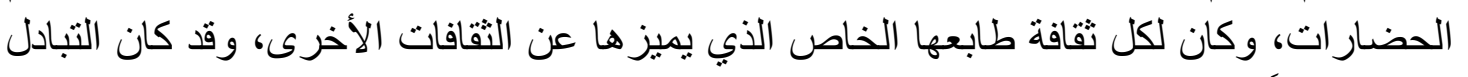

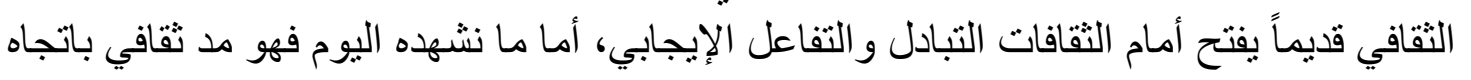

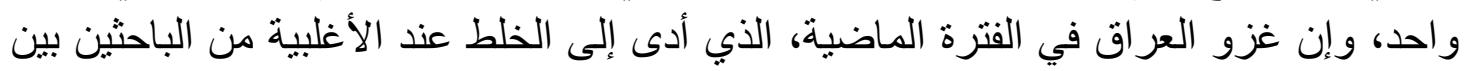

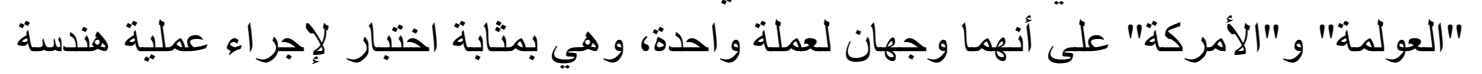

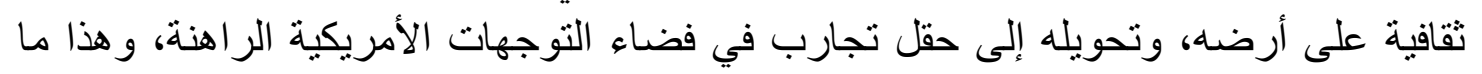

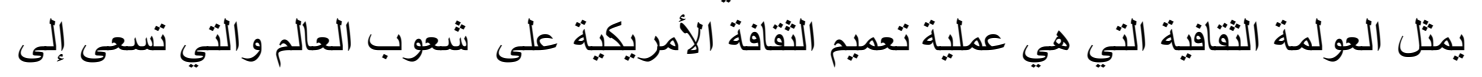

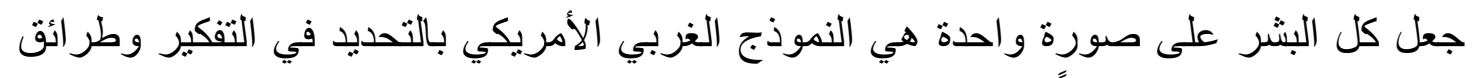

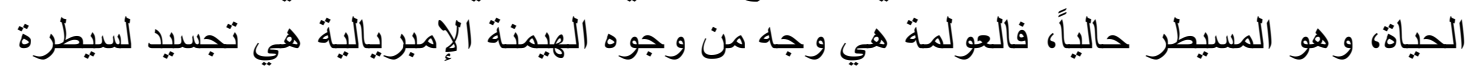

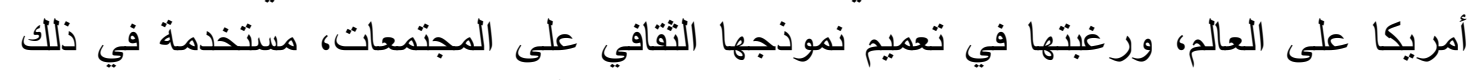

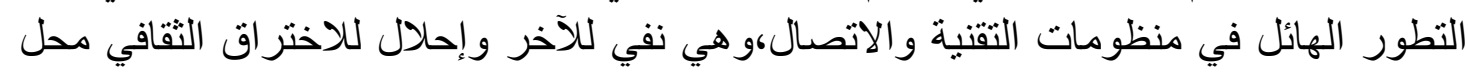

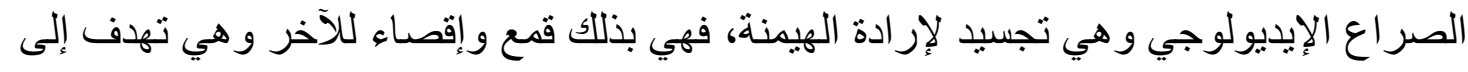

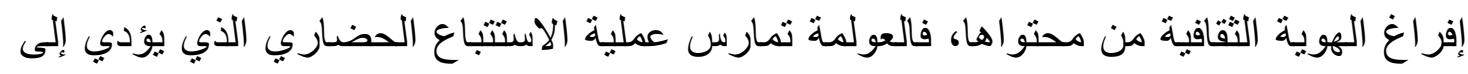

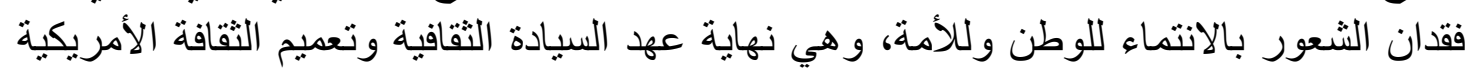
على العالم.

\section{المبحث الأول: موضوع البحث وأهميته والمفاهيم الأساسية}

\section{أولاً: موضوع البحث:}

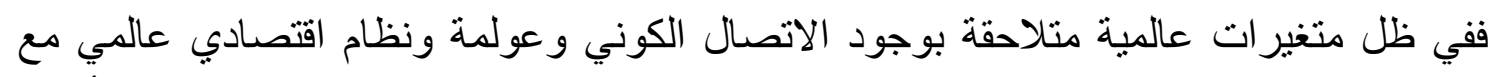

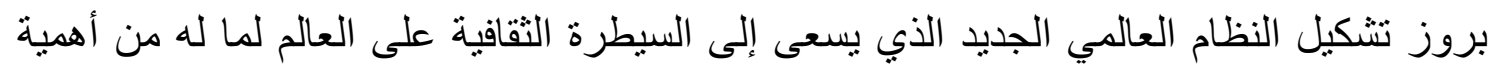

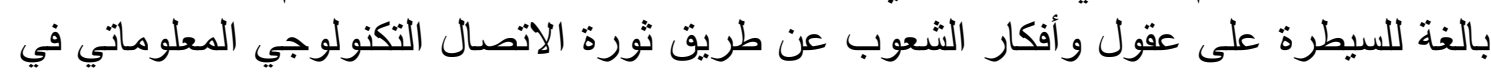

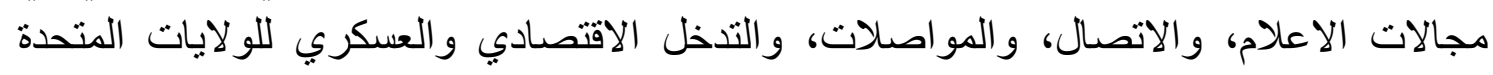


الامريكية في العراق من دون أدنى اعتبار للمواثيق الدولية وغير ها من الدول التي تهدد مصالحها

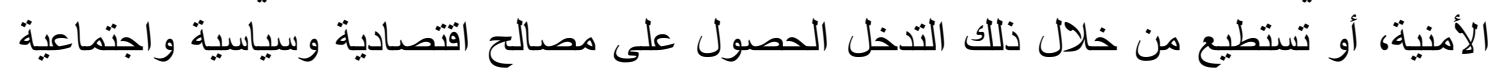

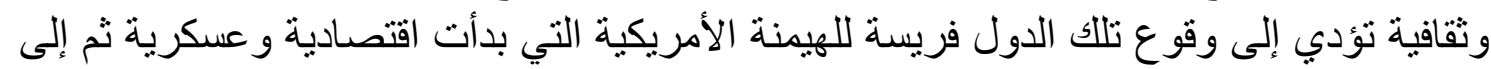

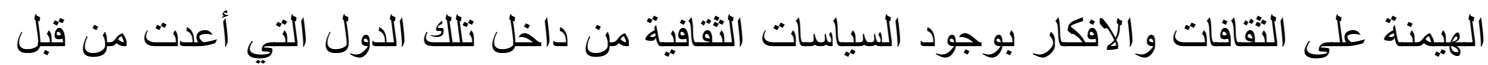

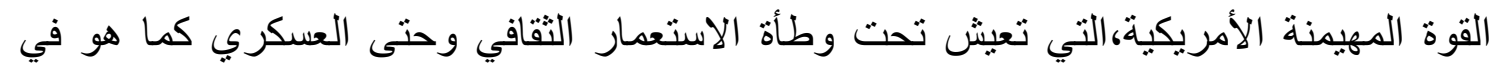

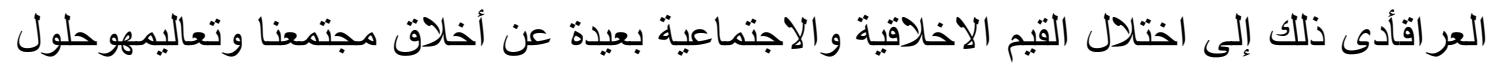

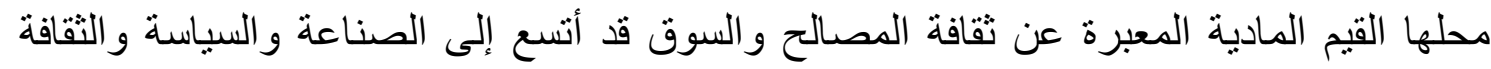

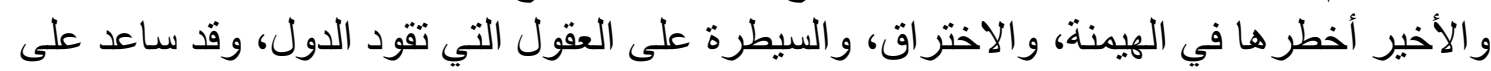

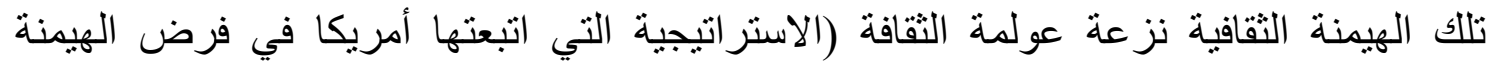

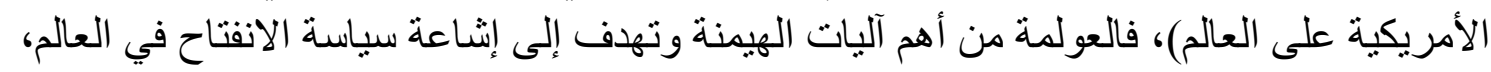

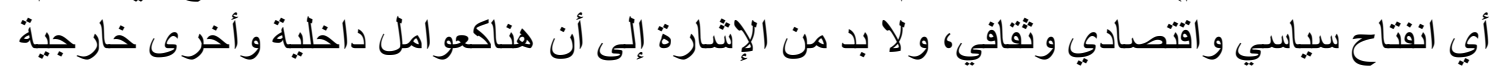

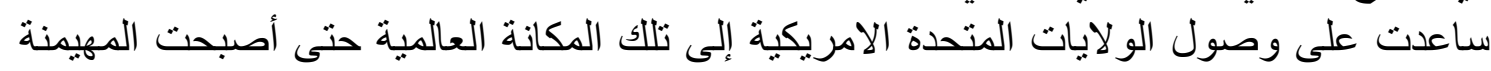

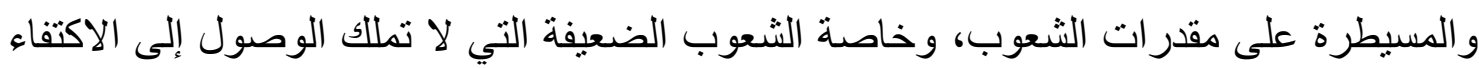

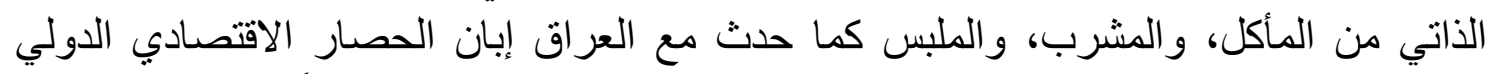

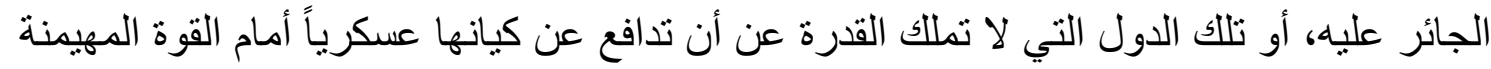

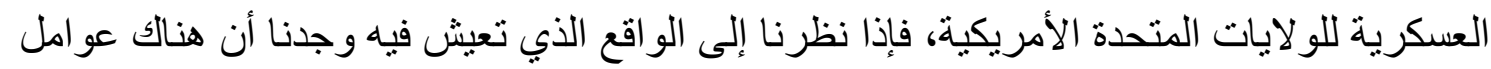

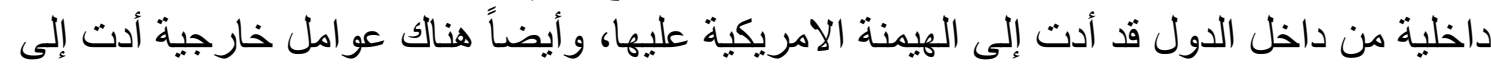
تللك الهيمنة، وأخص بالذكر هنا الهيمنة الثقافية التي تهنم بها تلإلك الدر اسة.

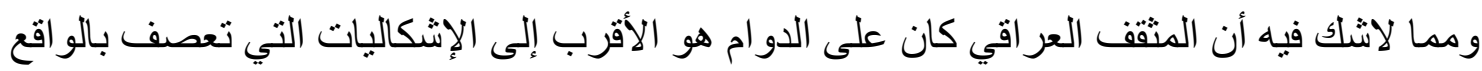

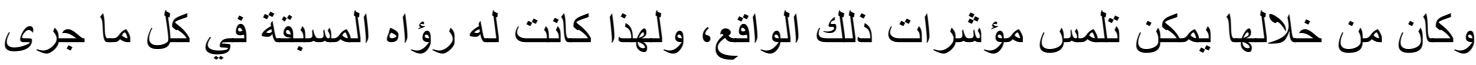

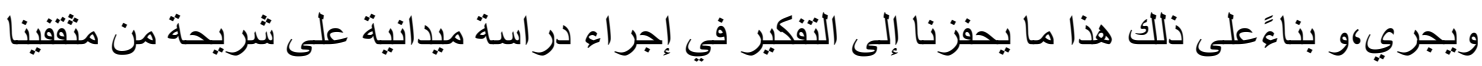

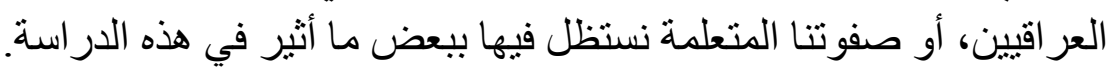

\section{ثانياً: تساؤلات البحث}

لتوفير فهم لمشكلة البحث يرى الباحث ضرورة توجيه الدراسة بالتساؤل الرئيس المتمنل بالآتي:

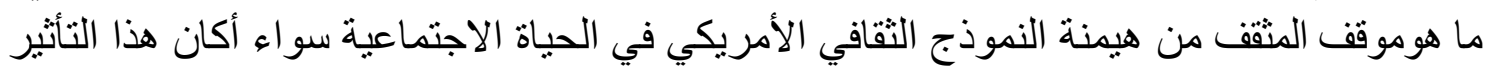

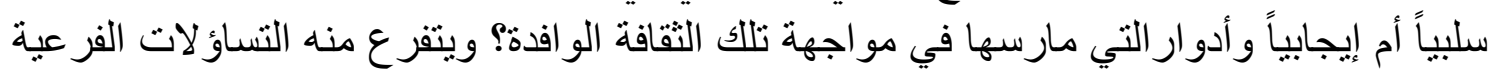

1- ما العو امل التي أدت إلى هيمنة الثقافة الأمريكية في العر اق من وجهة نظر المنقف العر اقي؟

2- ماهي المظاهر التي من خلالها يتضح رفض العراق للهيمنة الامريكية من وجهة نظره ؟ 
3- ما هي المعوقات التي تقف وتحول دون هذا التطابق، أب ما هي تللك الظروف المجتمعية التي تحول وتُحد من الدور المتوقع من المثقف العر اقي في الهيمنة الثقافية الأمريكية ؟ ثُالثا: أهداف البحث 1-التعرف على الأدوار التي يتعيَن على المثقف العر اقي اتخاذها لمو اجهة الهيمنة الأمريكية وموقفه منها. 2-التعرف على العوامل التي أدت إلى هيمنة الثقافة الأمريكية في العراق من وجهة نظر المنقف العر اقي تحديداً. 3- التعرف على مظاهر رفض العراق للهيمنة الأمريكية من وجهة نظر المثقف العر اقي. 4- التعرف على المعوقات التي تحول وتحُد من الدور المتوقع من المثقف العر اقي في مواجهة الهيمنة الثقافية الأمريكية.

$$
\text { رابعاً: أهمية الاراسة }
$$

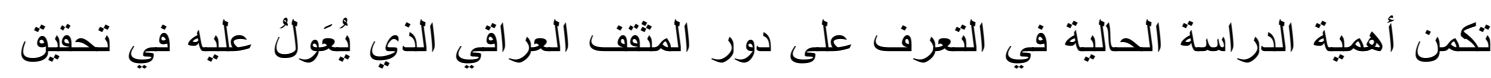

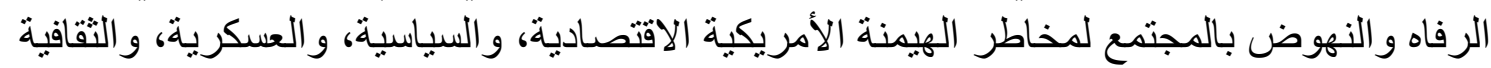

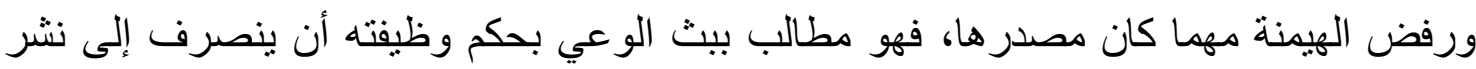

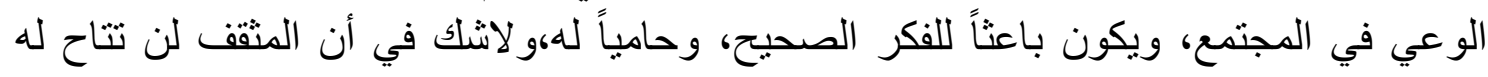

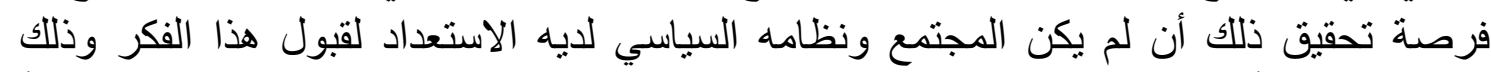

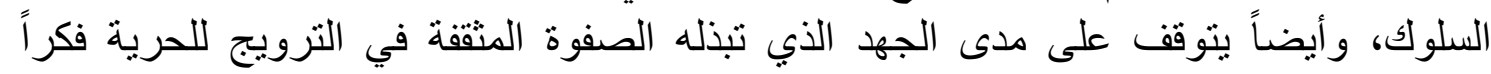

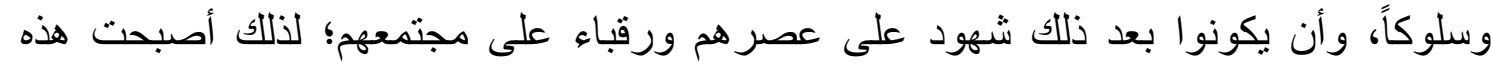
القضية جديرة في تناولها بالبحث وكيفية مو اجهة المثقف العر اقي لهاء

خامساً: مفاهيم البحث

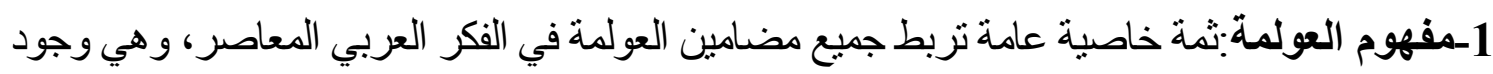

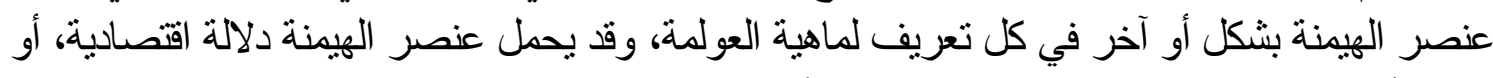

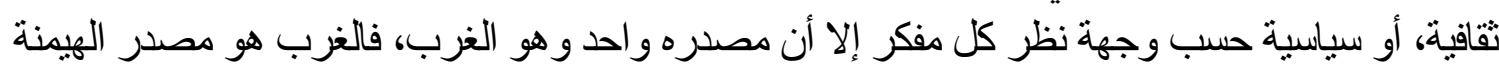

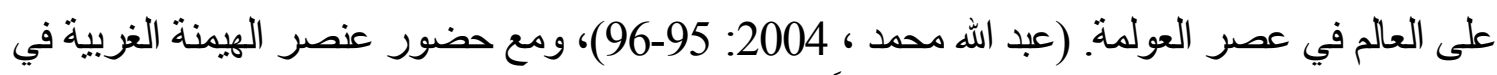

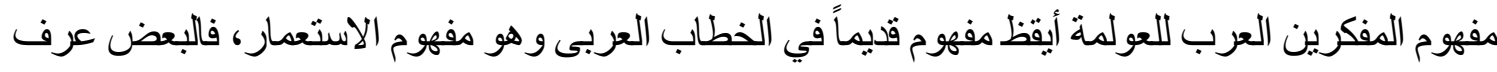

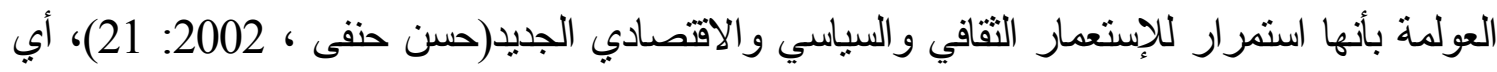
فرض الطابع الأمريكي في التفكير، والنموذج الأمريكي في الاقتصاد، وأخلاق الثقافة و السينما الأمريكية 


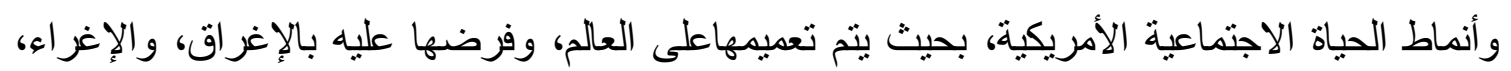

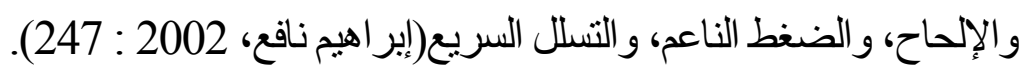

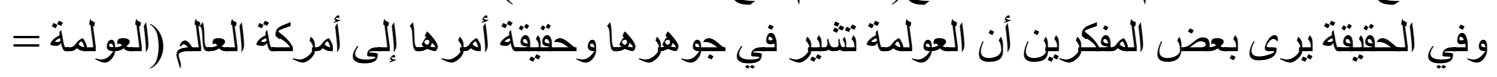

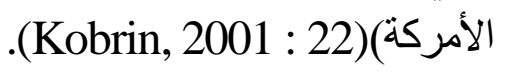

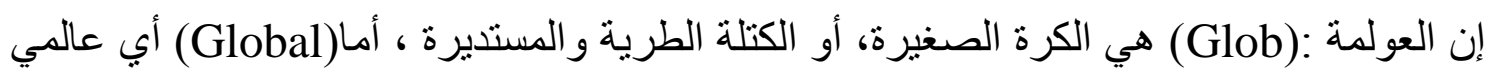

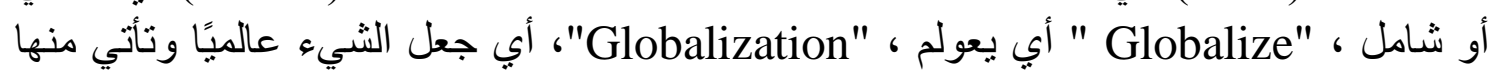

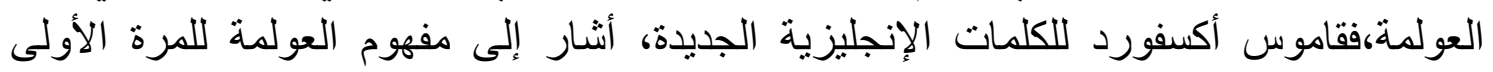

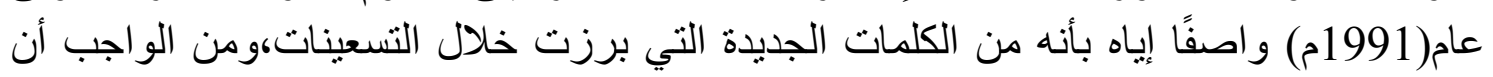

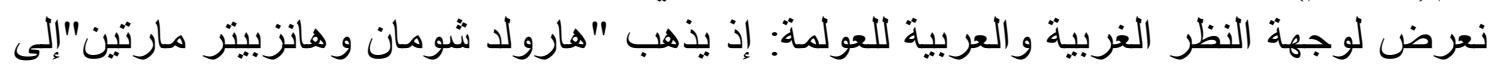

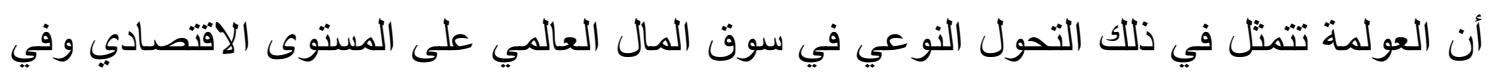

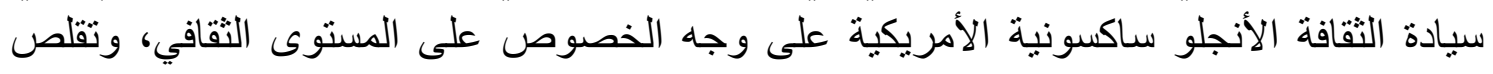

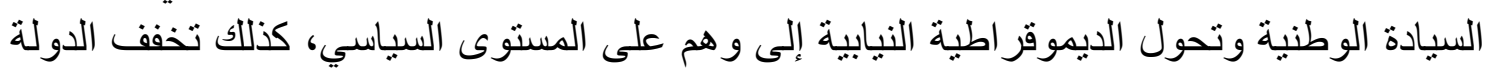

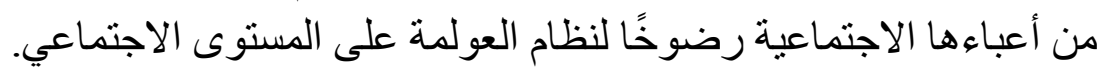

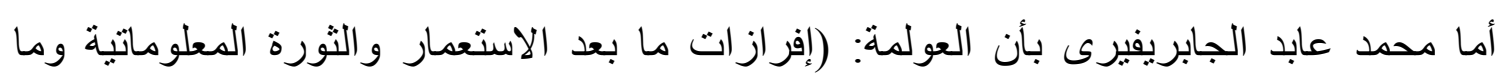

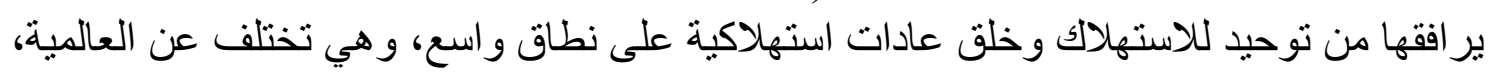

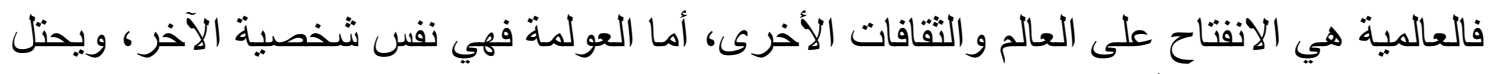

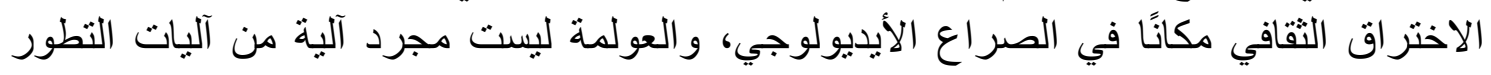

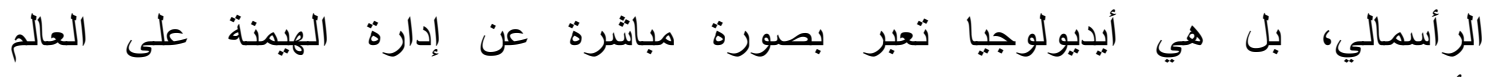

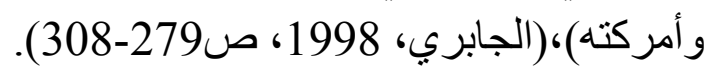

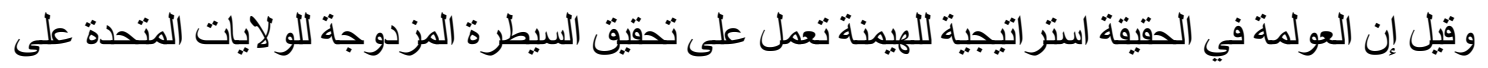

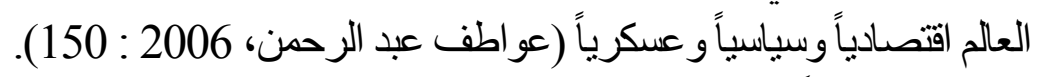

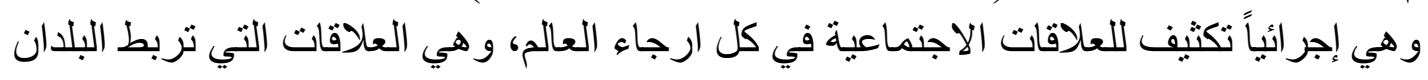

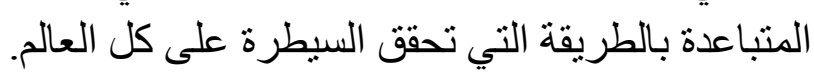

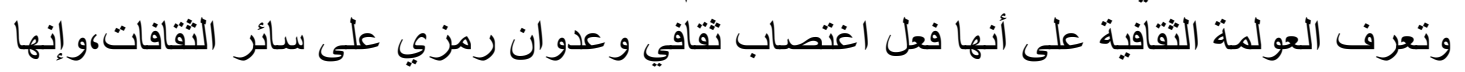

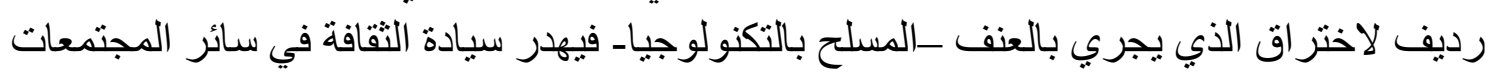

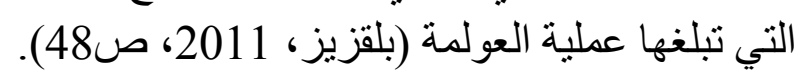

وتعرف العولمة الثقافية إجرائياً السيطرة الثقافية الأمريكية على سائر ثقافات العالم، من خلال وسائل الاتصال و التكنولوجيا المتقدمة. 
2- مفهوم الهيمنة:إن مفهوم الهيمنة مفهوم و اسع ومشتت يختلف الباحثين في تحديده وذللك بحسب المنظور الذي ينطلق منه الباحث، و الرؤية التي تؤطر ذلك المنظور، فالبعض يتحدث عن الهيمنة التهنة

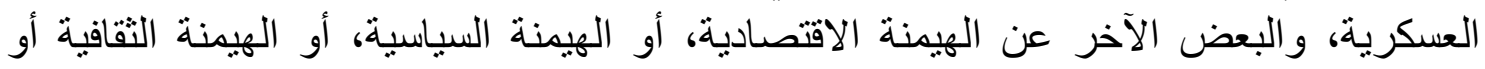

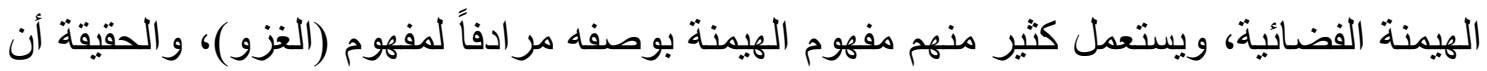
كل أنواع الهيمنة تعتمد بنسب عالية جداً وبصورة مباشرة أو غير مباشرة على مقدار التقدم

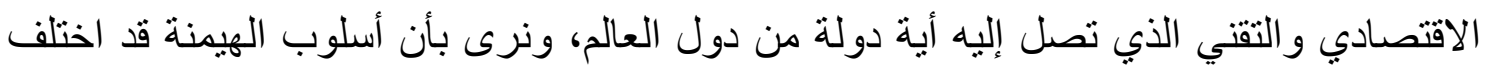

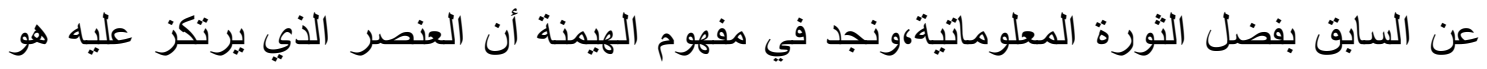

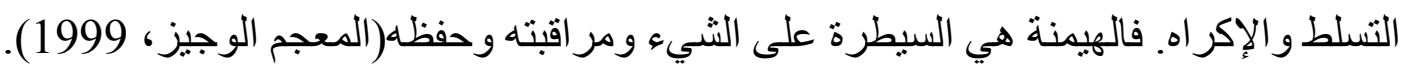
و عرف جر امشي الهيمنة أسلوب الطبقة البرجوازية في التحكم حتى في الأنظمة الديمقر اطية وذلك

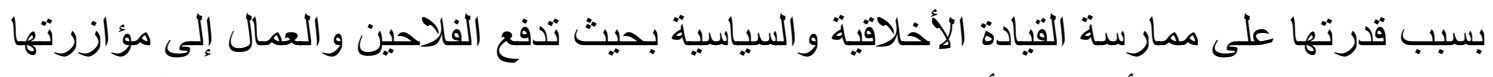
ومن ثم يرى جر امشي أن نجاح أي نظام سياسي مر هون بابتداع، كتلة تاريخية تتحد حول مشروع

الهيمنة يسمح للطبقة المهيمنة بتكوين تحالفات تجذبها نحو أفكار ها. ( Gramsci, p. 116, 418). في حين عرفها ور آها تمثل" السيطرة السياسية والاقتصادية والعسكرية على G. Murdick" مقدر ات الدول المختلفة". (Murdick,1975, p.438).

وتعرف الهيمنة على أنها "فرض ثقافة معينة من المتسلط على المتسلط عليه بشكل ظاهر أو خفي". (الحنفي، 2000، ص2232)،أما التعريف الإجر ائي للهيمنةبأنها شكل من الايديولوجيا الاستعمارية أكثر كفاءة، يبرر عملية السيطرة ويطبعها بالاقناع.

3- مفهوم الثقافة: إن كلمة ثقافة في اللغة العربية تعود إلى الفعل (ثقف)، فقد جاء في لسان

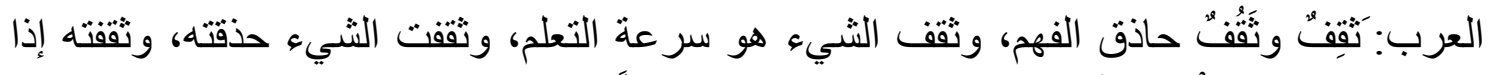

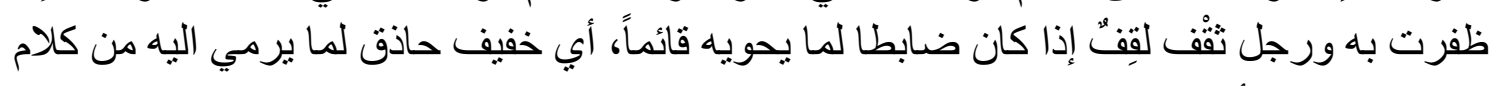

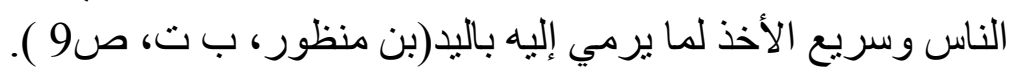

ونجد في معجم أكسفورد تعريفاً للثقافة فذكر أنها "طريقة الحياة الخاصة لثعب من الثعوب متميزاً

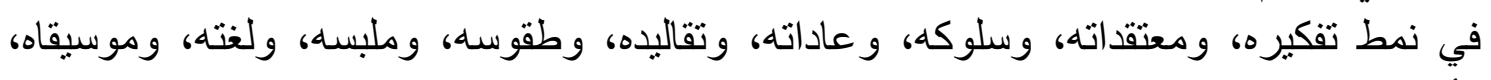

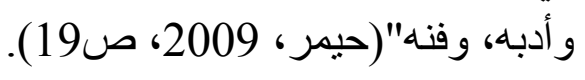

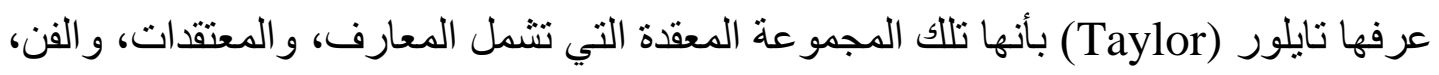
و القانون، والأخلاق، و التقاليد، و العادات، والعرف بان وكافة القدرات، و الأشياء الأخرى التي يكتسبها

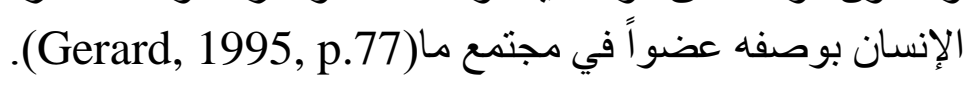




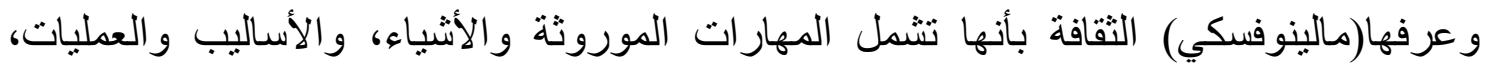

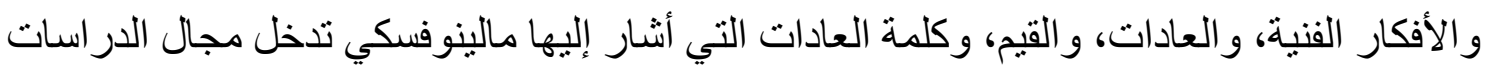

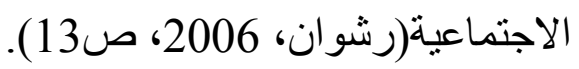

وتعرف الثقافة بمعناها الذي يشمل الفن، والأدب، والسينما، والممارسات التمثيلية بكل أنو اعها،

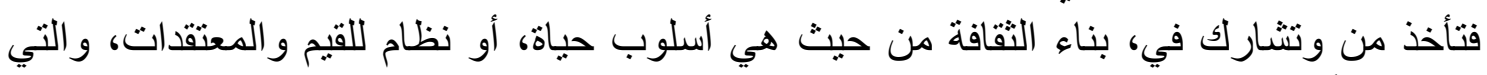

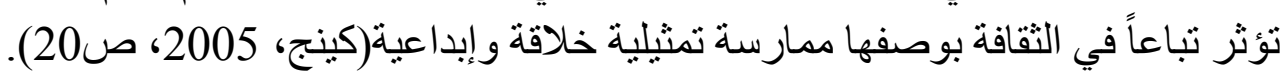

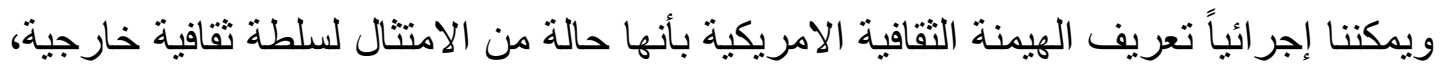

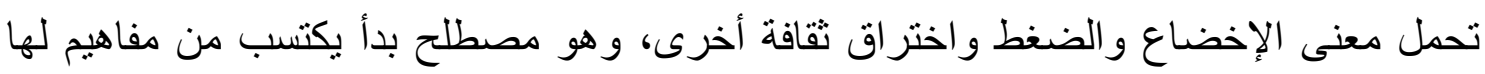

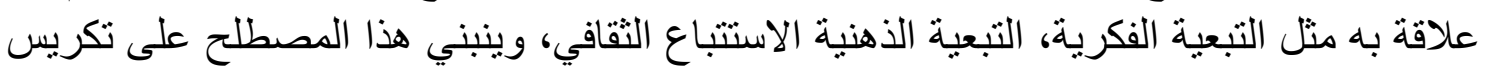

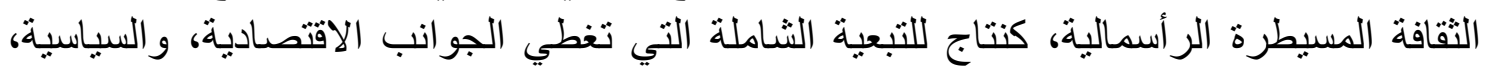
و التكنولوجية.

4-مفهوم المثقف: يثكل المثقفون فئة اجتماعية تتعامل مع منظومة الأفكار، في نطاق الإطار

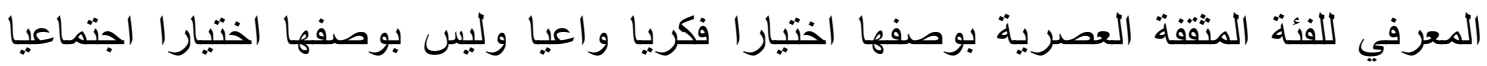
عاما(فياض،2006،صنم280-78).

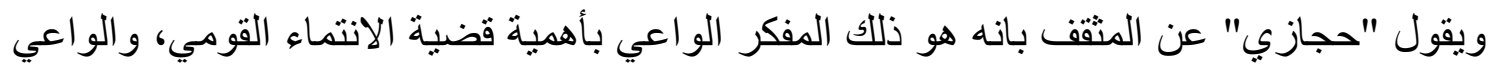

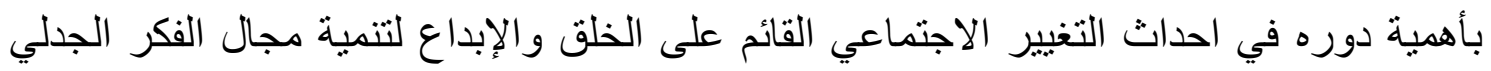

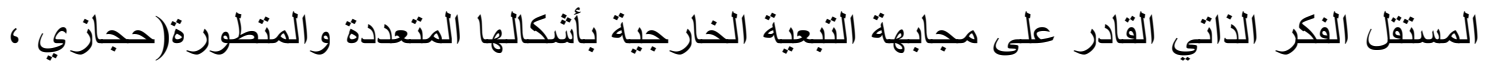

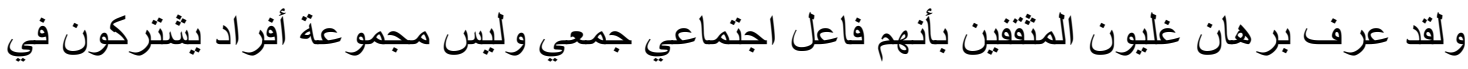

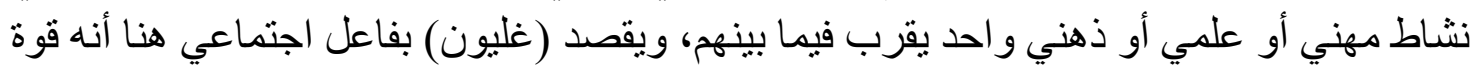

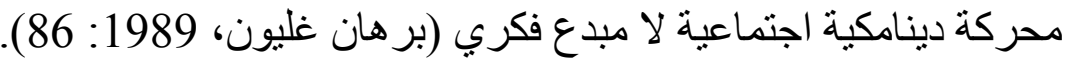

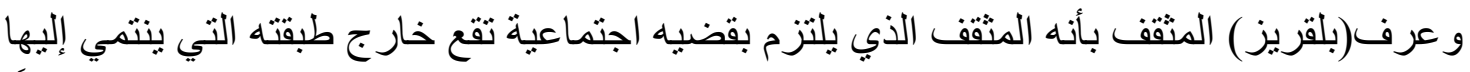

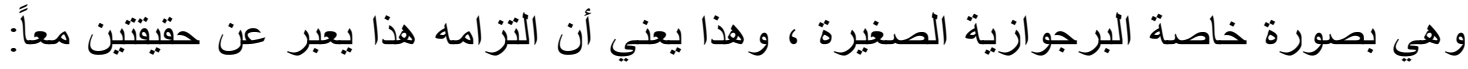

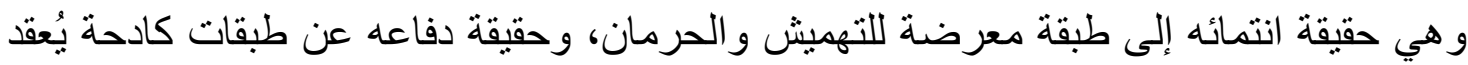

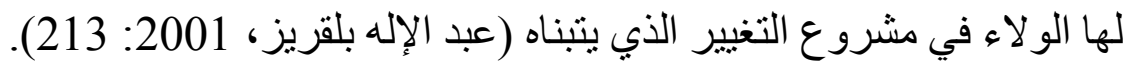
ومنأنماط المثققين في مناهضة الهيمنة الأمريكية بحيث ييرز من المتنقين من هو: 1- ناثنط فكري (أي تقتصر أدواره على الأنشطة، والأوار الفكرية، والتثقيفية، و التتويرية). 2- ناثططحركي (أي تتوقف أدواره في الحركة على الأدوار الحركية، والميدانية ). 


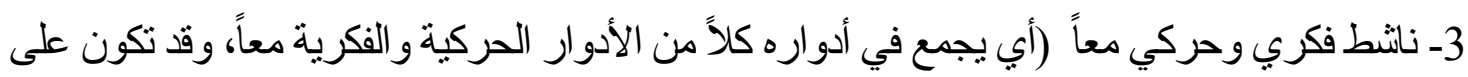
المستوى المحلي فقط ، أو العالمي فقط أو كلاهما معاً).

المبحث الثاني: المداخل النظرية في دراسة كل من المثقفين والهيمنة الثقافية

أولاً: المداخل النظرية لاراسة الهيمنة الثقافية: سوف يكرس الاهتمام هنا على توضيح النظريات

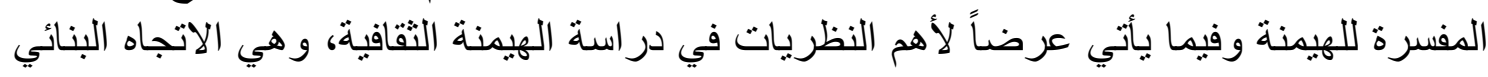
التاريخي، ونظرية التبعية، وتوضح بالثي لأشكل الآتي:

1-الاتجاه المادي التاريخي:من خلال الاتجاه المادي نستطيع تفسير الظاهرة في ضوء الإي التحليل

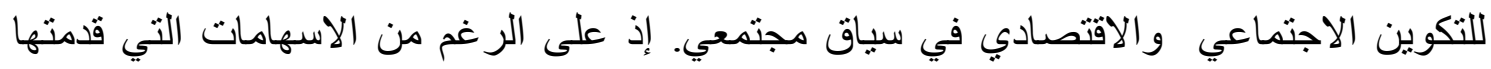

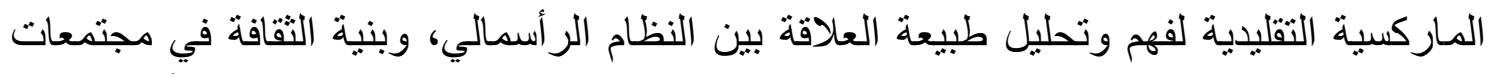

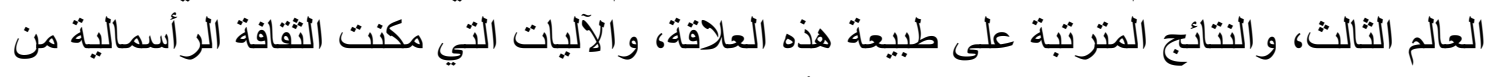

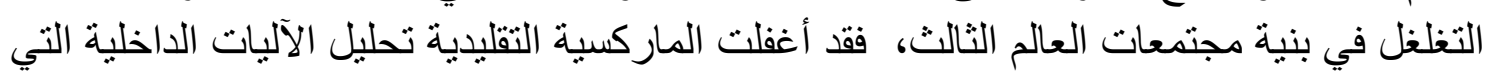

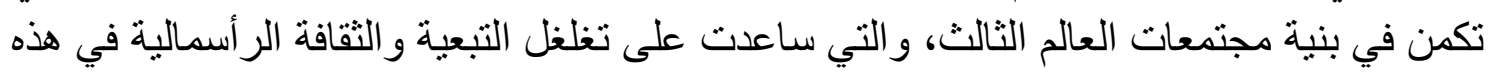

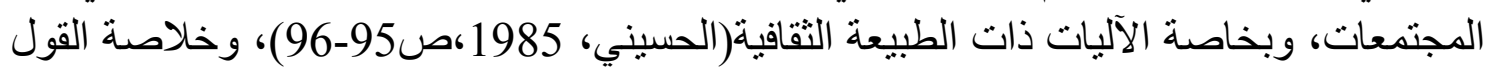
في ذللك أن الفكر الماركسي التقليدي لم يعد كافياً لتحليل بنية الثقافة في مجتمعات العالئ العالم الثالث،

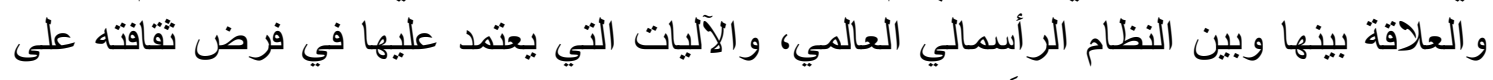

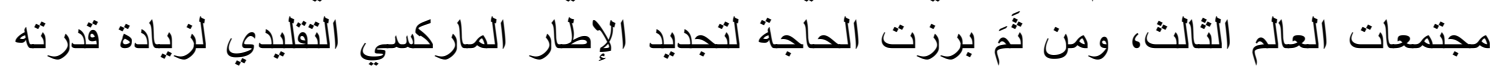

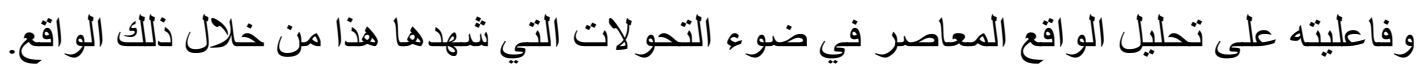

تبلور الاتجاه الماركسي الجديد والاتجاه النقدي الذي يرى في الإني البناء الاجتماعي القائم مرحلة انتقالية

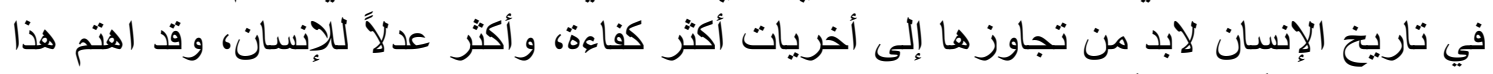

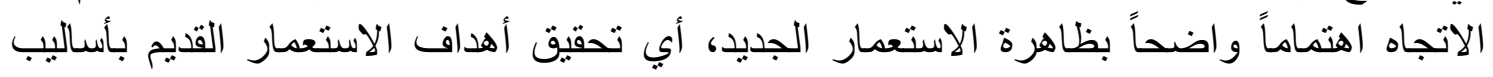

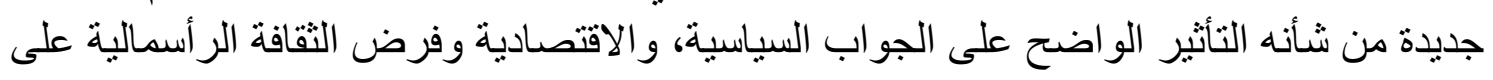

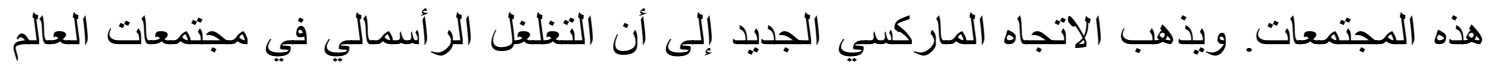

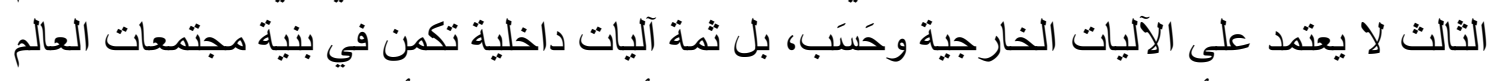

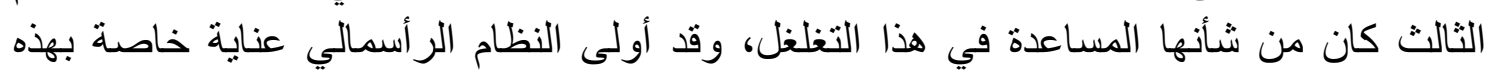

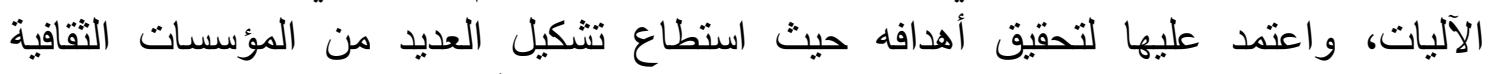

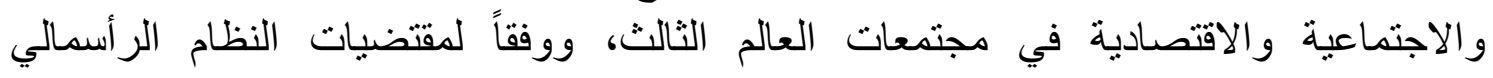

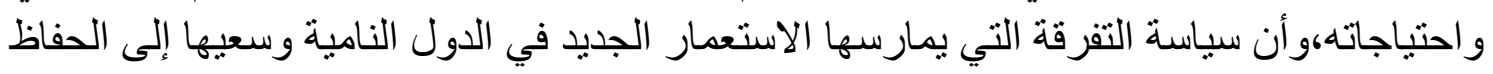

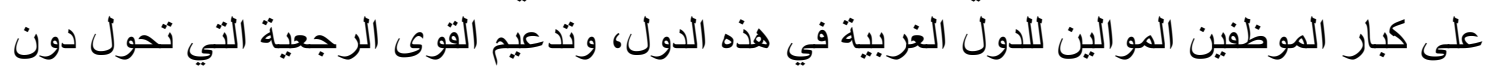

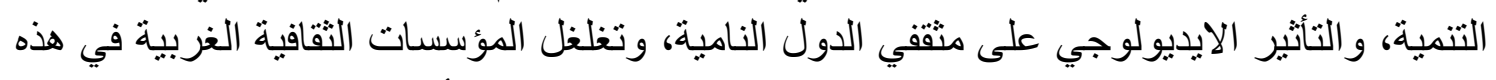
الدول، وتدعيم القوى الرجعية التي تحول دون التئية التنمية، والتأثير على وسائل الاتصال 
الجماهيري(عبد المعطي، 1981،ص63)،ومن خلال صياغة الرؤية الماركسية لواقع مجتمعات

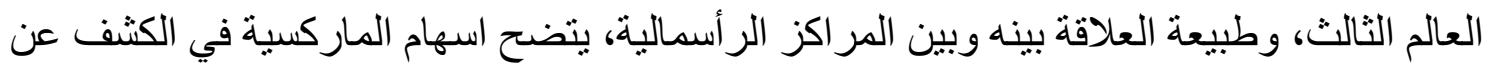
الأبعاد الايديولوجية للنظام الر أسمالي العالمي، وأثز القوى الاستعمارية في خلق وتكريس التبعية و التخلف في مجتمعات العالم الثالث.

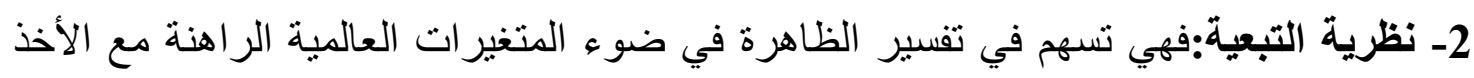

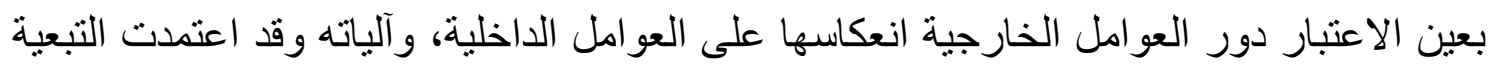
الثقافية على النقاط الآتية: 1- لا يمكن عزل الثقافة عن كل ما هو مجتمعي و اقتصادي، وسياسي، و اجتماعي. 2- لفهم أبعاد أي ثقافة معاصرة يجب فهم جذور هذه الثقافة ومر احلها التاريخية. 3- إنْ مجالات ومستويات التبعية الاقتصادية تؤثر بشكل غير مباشر على التبعية التقافية. 4- إن فهم التبعية الثقافية تقييماً ومو اجهة يتطلب تحديد أهم خصائص الثقافة المحددة التي يحدث فيها فعل التبعية.

5- تعد التبعية الثقافية حالة خاصة ونوعية من حالات التبادل التقافي يمكن وصفه بأنه تبادل لا منكافئ لصالح الثقافة المهيمنة.

كان لابد أن يوضع تقويماً عاماً لمرحلة الاتصال الأولى بالغرب عن طريق الاستعمار

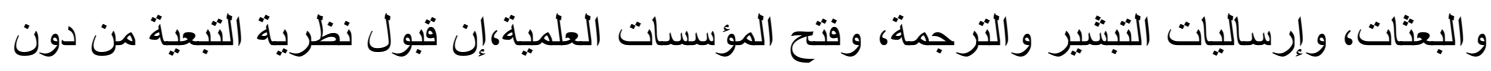
وضعها تحت نظر نقدي تعني أن المجتمع الغربي وثقافته تعتبر صورة نموذجية مثلى في كل

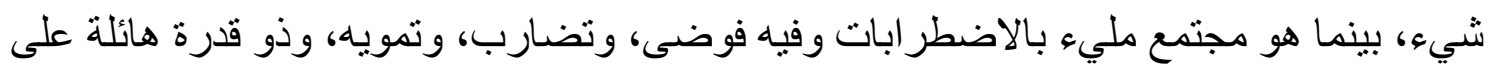

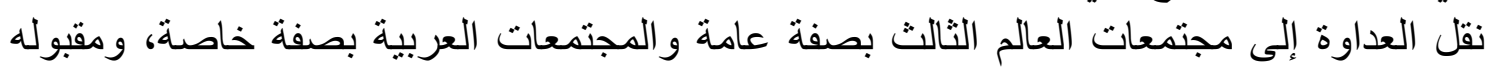
هكذا دون فرز نقدي يجعل حالنا معه حال المقلدين دون النظر إلى الاختلافات القيمية والثقافية بين

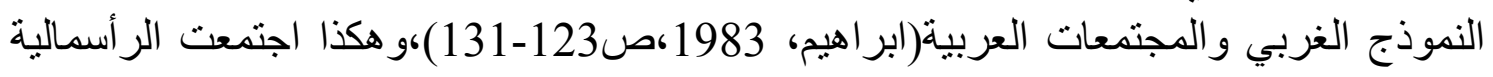
و التبعية الرأسمالية فهي وحدة جدلية جمعت الاستعمار الجديد و المناطق التابعة، وهي وحدة ذات

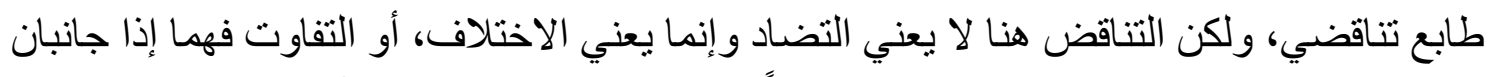

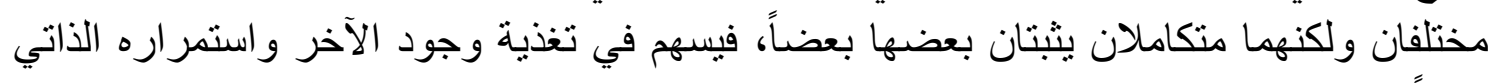

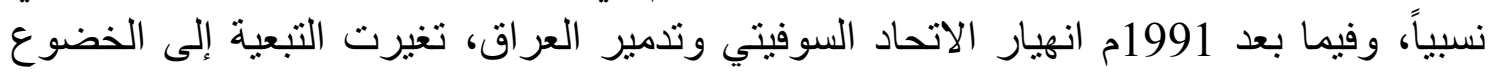

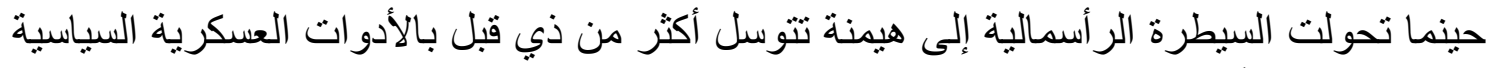

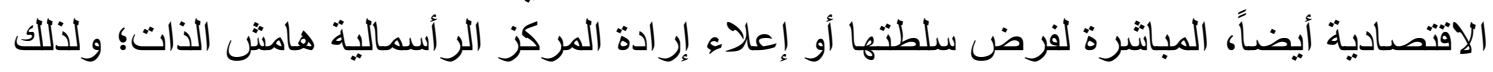


يحق لنا أن نوصف العلاقة بين الطرفين منذ نهاية التسعينات بأنها علاقة الهيمنة_الخضوع،إن

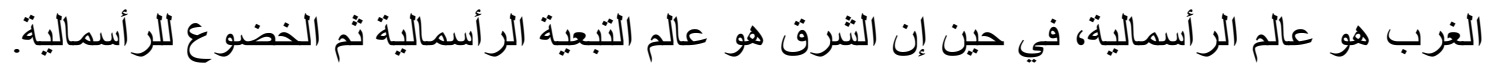

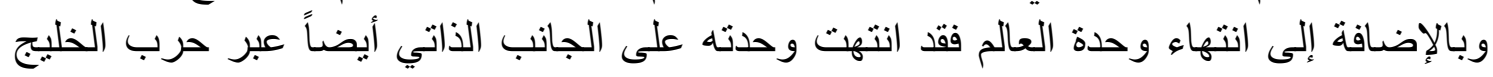

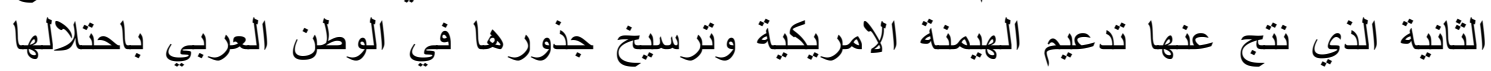

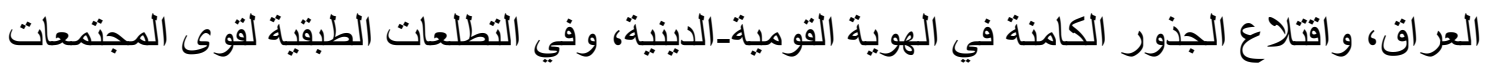

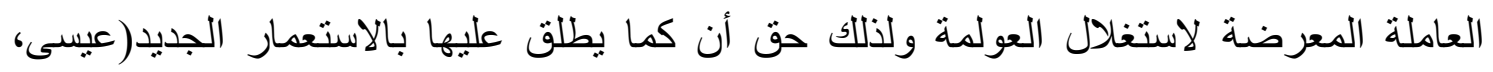

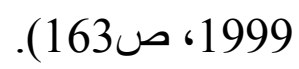

ثاتياً: المداخل النظرية في دراسة المثقفين: من أشهر التصورات النظرية في مجال المثقفين الرؤى

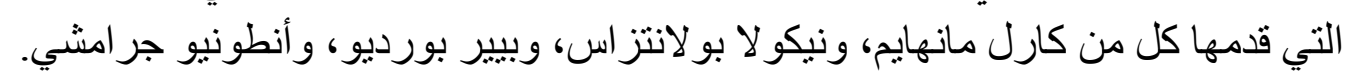

1- كارل مانهايم: يرى كارل مانهايم أن المثقفين يمكن أن ننظر لهم-وبصورة سبية- بوصفهم فئة

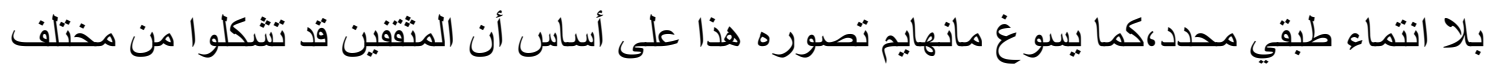

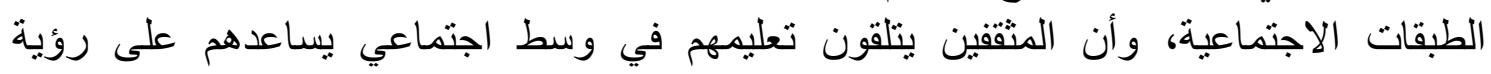

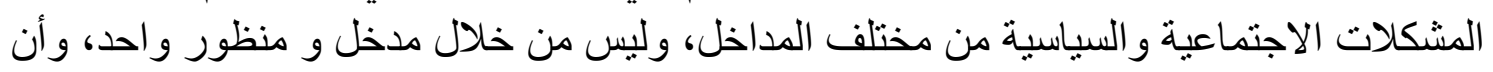

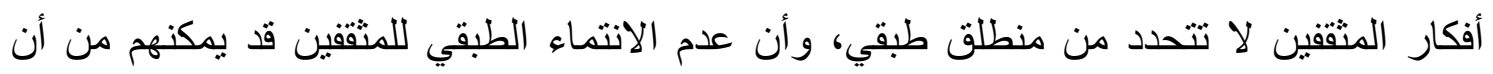

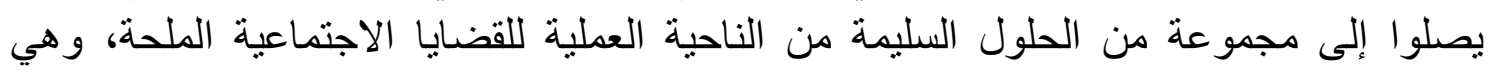
الحلول التي لا تعبر عن وجهة نظر طبقية خاصة.

2- نيكولاس بولانتزاس: يرى بولانتز اس، إن المثقفين بإعتبار هم موظفي الدولة يدخلون في شبكة

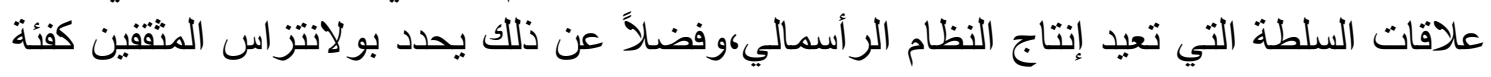

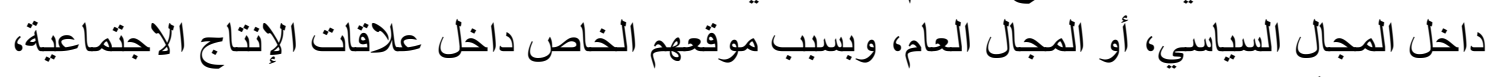

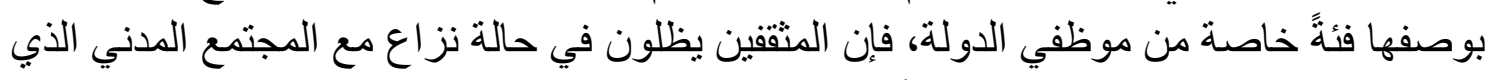

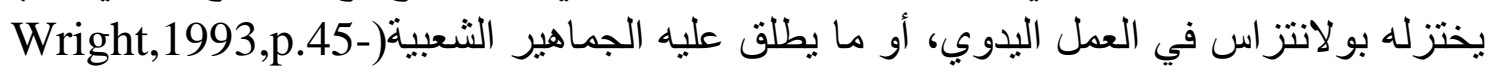

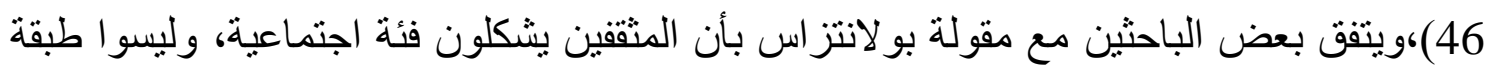

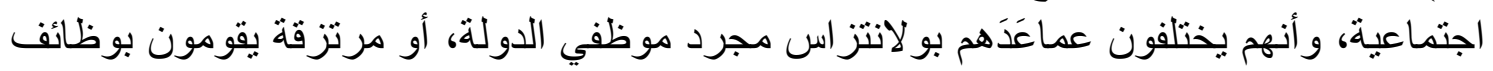

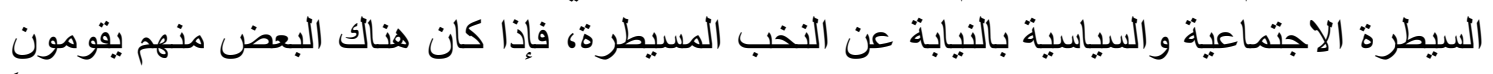

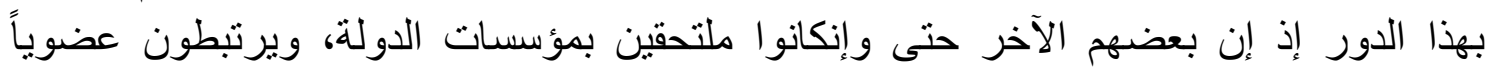

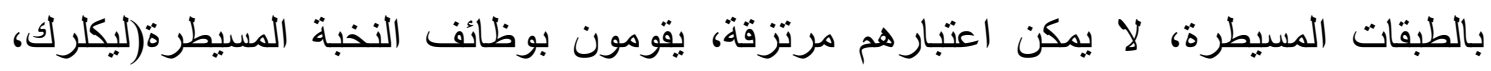

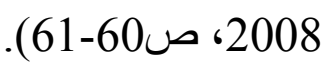

3- بيير بورديوP. Bourdieu : المثقف عند بورديو ليس فرد في القطيع يتلقى الأوامر والأفكار

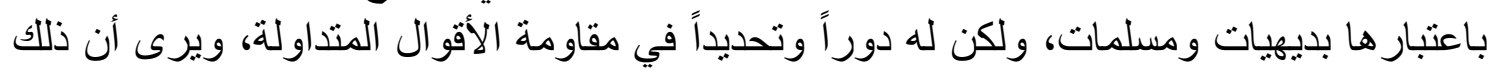




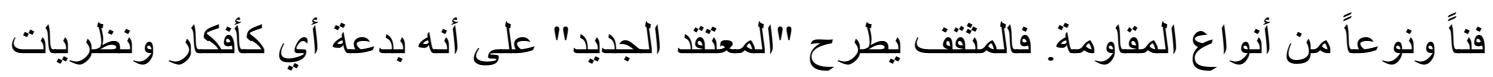

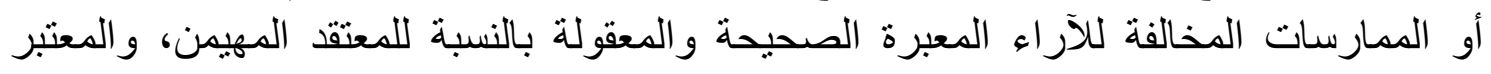

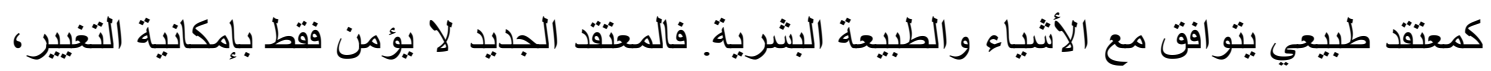

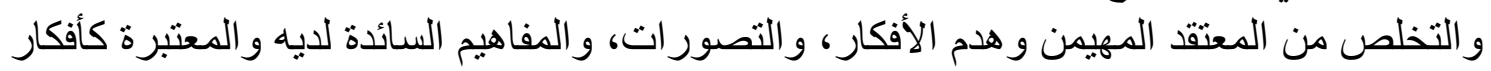
ومعتقدات صحيحه، بل يسعى إلى بناء رؤية جديدة تطرح توقعات مناقضة لتوقعات المعتقد المهيمن، بل يرى بورديو أن المعتقد الجديد يأمل في أن يتحول هذا الكلام و المعتقد الجديد من آراء

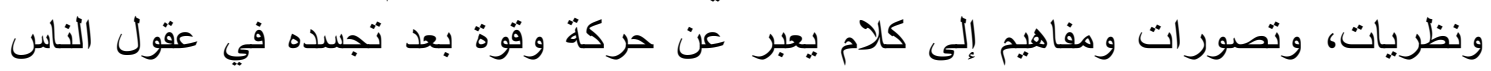

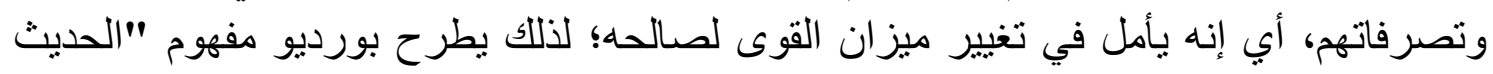

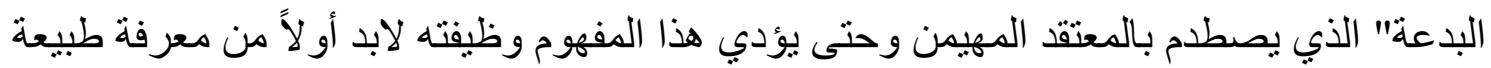
الصر اع و الأطر اف المتصار عة، أي وضع الفئات المهيمنة التي تكرس نظامها وتعطي انطباعاً أنه

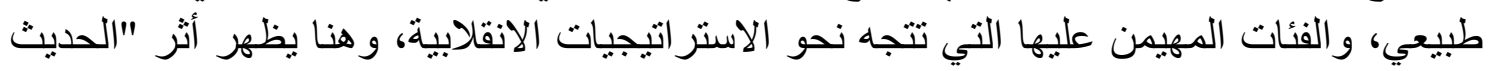

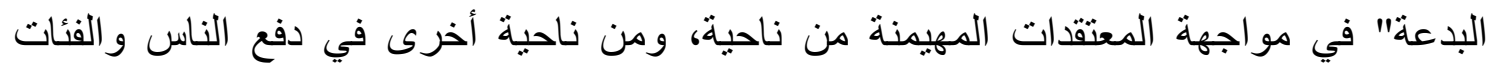

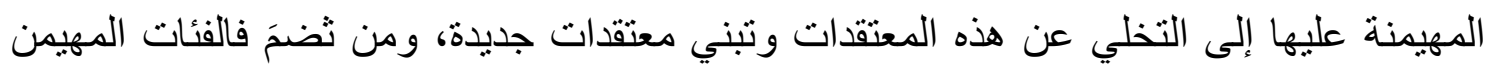

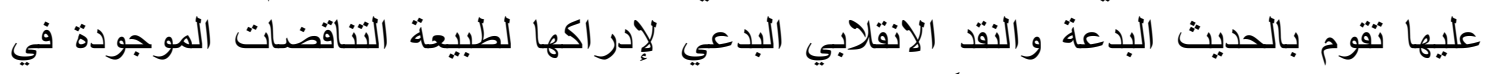

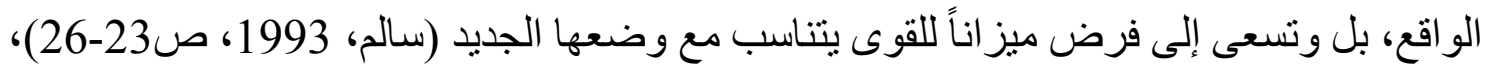

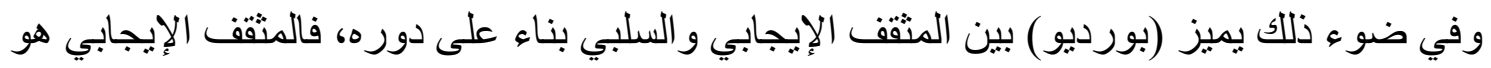
المثقف الذي يتمثل دوره في نقد الآراء، وفي التعبير عن آر ائه بحريه في مو اجهة القوى المسيطرة، لئهي

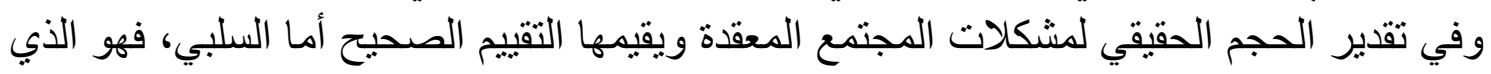
يكون من حجم وخطورة المشكلات ومن ثََّ الحلول المطروحة لهاع (224-26p.Smith,1998).

4- أنطونيو جرامشي: لقد اعتمد جر امثي في تحديده لمفهوم المثقف على معايير جديدة تختلف عن

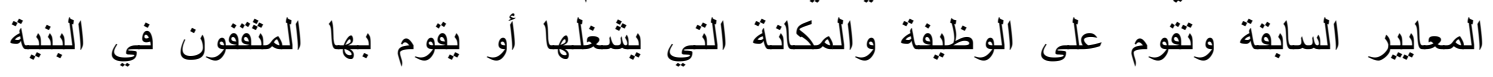
الاجتماعية، وقد اتسع مفهوم المثقف لاى جر امشي بإن كل الناس مثقفون وليس لكل إنسان وظيفة

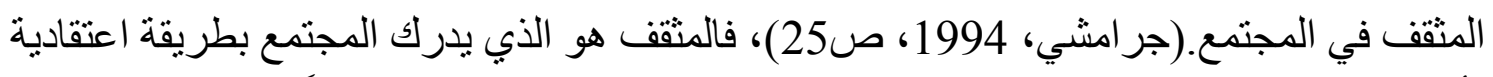

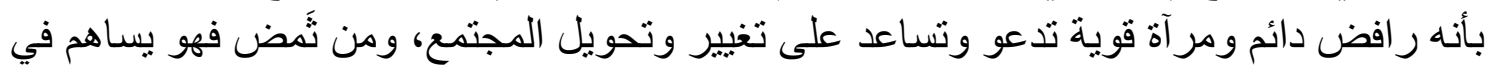

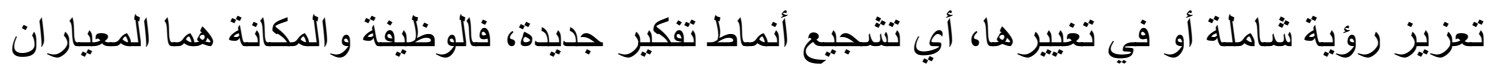
الأساسيان في تكوين المثقف، أي إن تلك العلاقة هي شرط أساس في تشكل و إنتاج المثقفين. حيث يتوسط تلك العلاقة بدرجات متفاوتة نسيج المجتمع كله ودركب الأبنية الفوقية التي يعتبر المثقفون

موظفو ها.

المبحث الثالث: سياسة الهيمنة والزعامة الأمريكية على العالم

أولاً: المثقف العراقي في عصر عولمة أم هيمنة غربية 
إن العولمة هي (نظام جديد من العلاقات بين الثقافات يعطي أرجحية للإنتاج الثقافي الأمريكي بحكم هيمنة الو لايات المتحدة على صناعة الإتصالات و المعلومات) (عبد الله محمد، 2004 : 115)،و إن الهيل الهيمنة

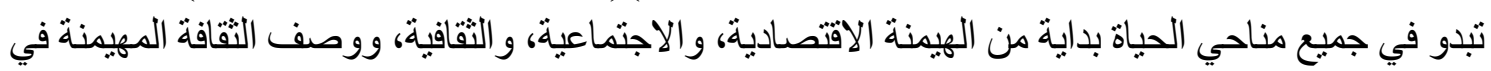

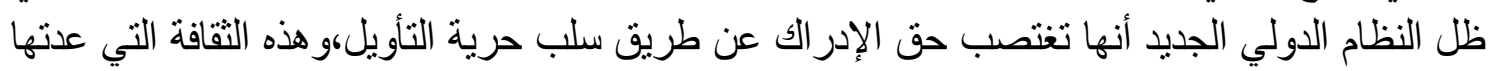
اللغة وسلاحها الخطاب وصاحبها استراتيجية الاعلام التي بستخدم فيها المتسلطون أنه خطاب لقمع حرية الفكر في أن يفكر خارج دوائر المناورة (عبد الفضيل، 1999، صأدئة 172)، وإن مسؤولية المثقف بشكل عام

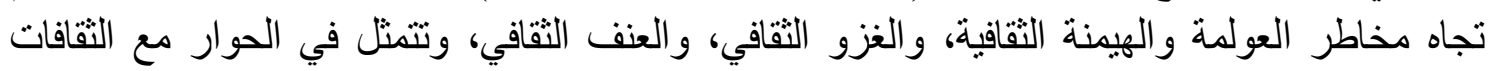

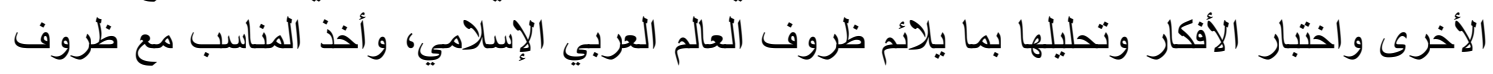

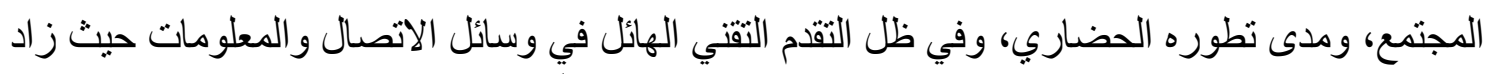

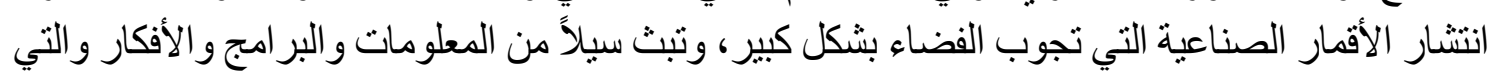

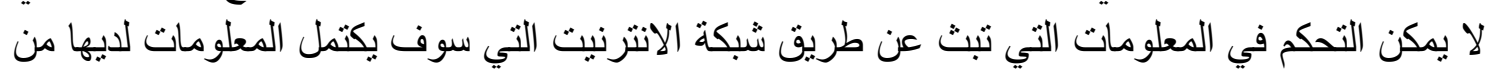

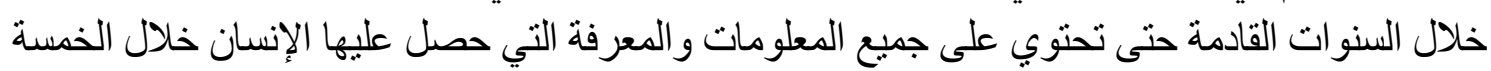

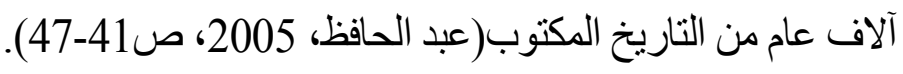

ثانياً: مظاهر الهيمنة الامريكية على النواحي الاقتصادية والاستثمارية ونقل التكنولوجيا إلى العراق تُعَدُ الهيمنة الثقافية من أخطر أنواع الهيمنة، فالتهيئة الثقافية من خلال وسائل الإعلام و المعلومات

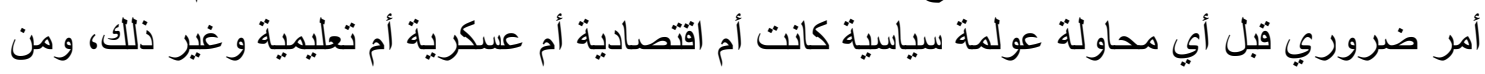

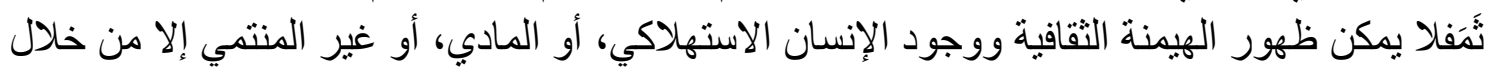

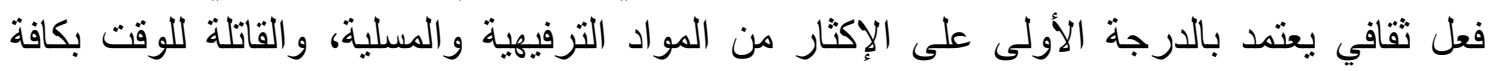

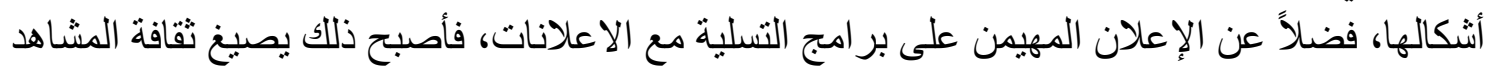

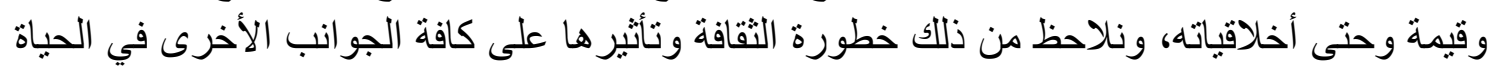

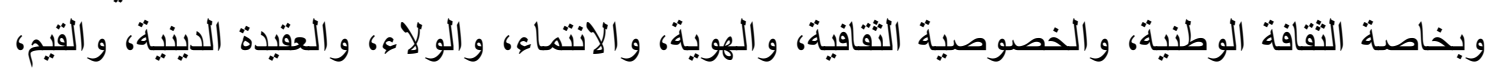

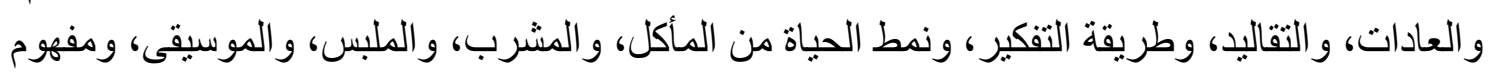

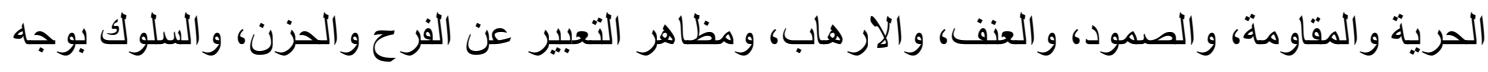

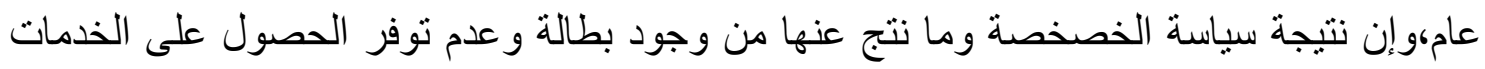

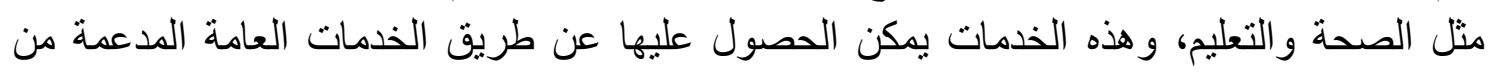

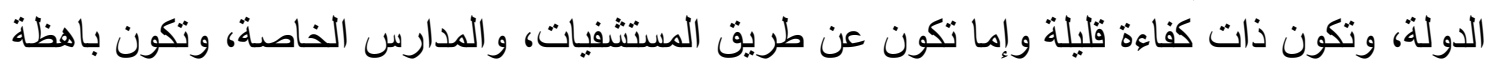

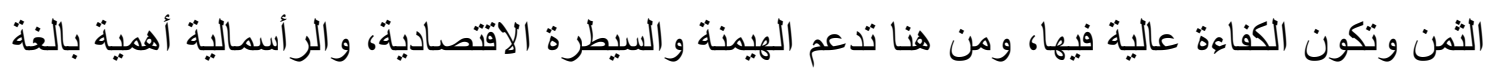

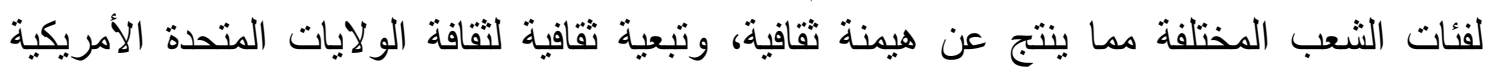

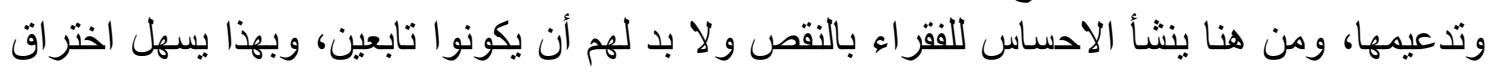

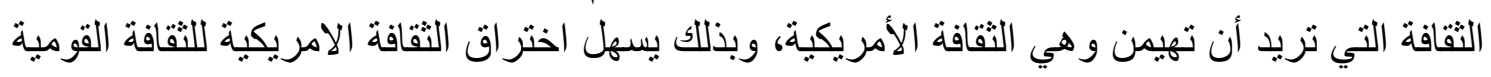

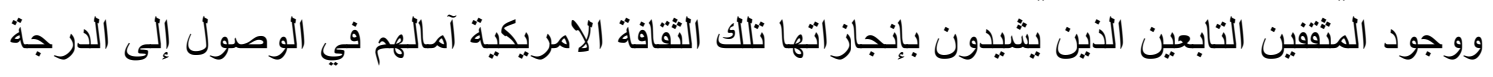


من تللك الثقافة، وذللك التقدم الذي ينعم به من يدينون بالولاء للثقافة والسياسة الامريكية، وبذلك يسهل

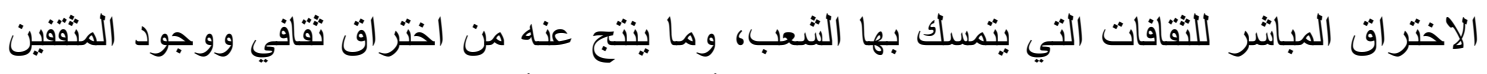

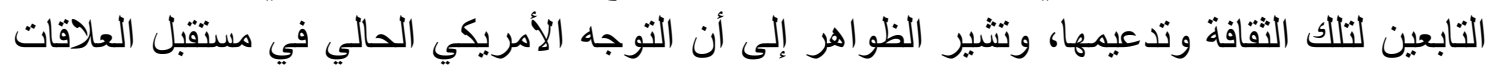

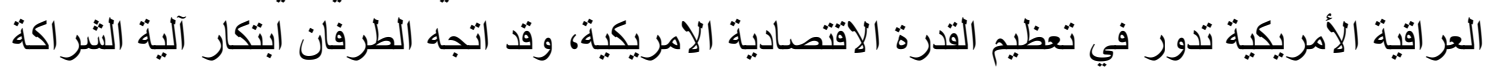

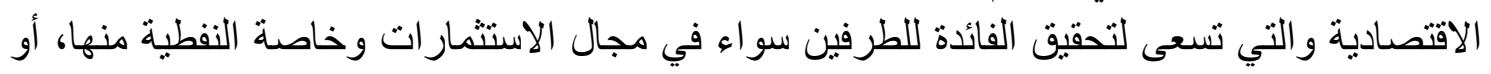

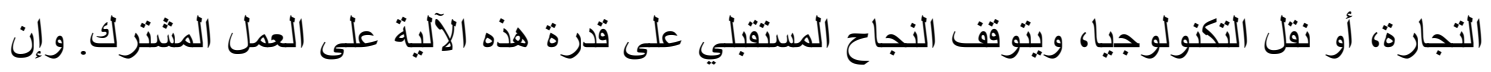

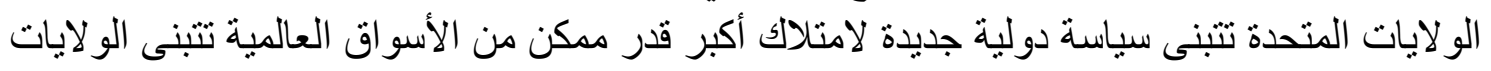

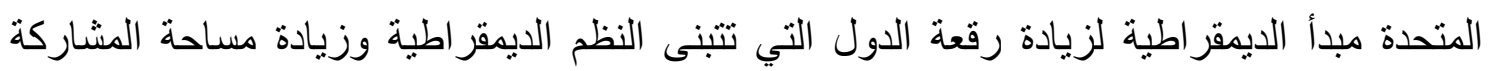
الثعبية في صنع القرار.

و ون أهم وجود الهيمنة الثقافية هو سيادة الثقافة الكونية للقطب الأوحد وانعدام الأمن الثقافي للثقافات الأخرى،

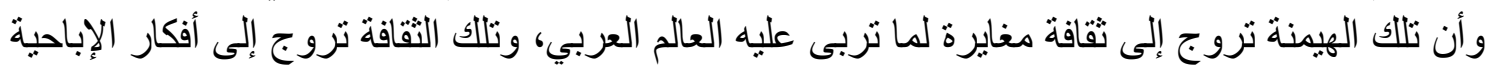

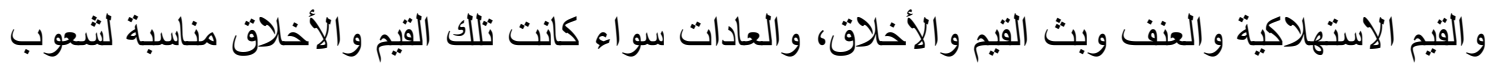

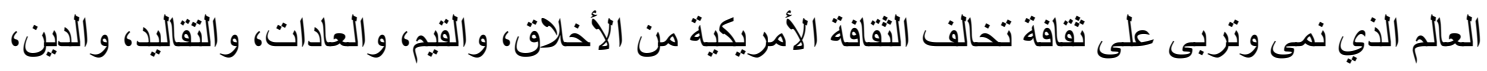

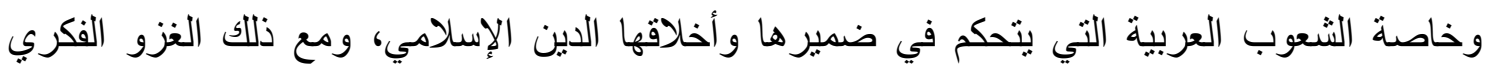

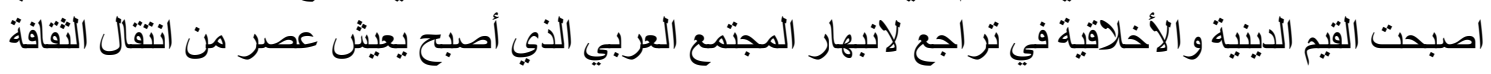

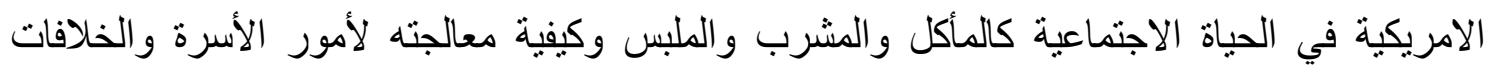

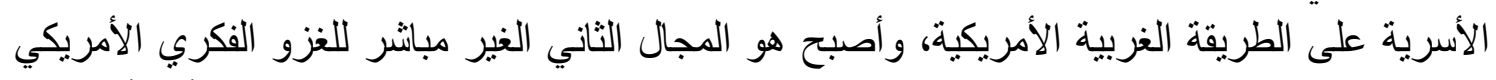

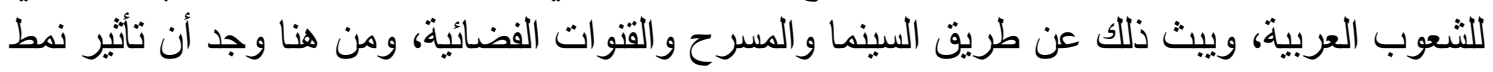

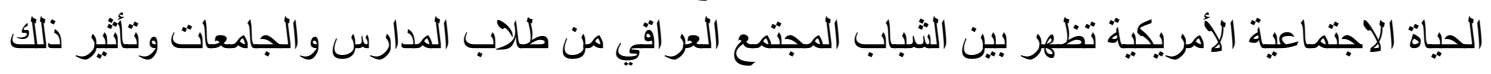

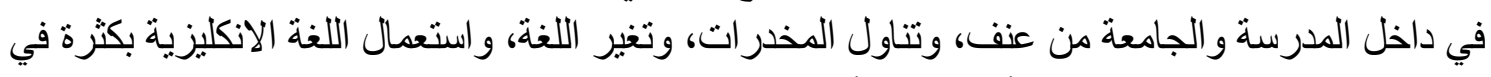

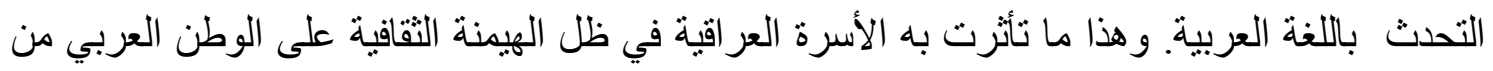
خلال القطب الأوحد الغربي الأمريكي.

ثالثاً: المثقف العر اقي في مو اجهة الهيمنة الامريكية بين المتوقع والمأمول وبين الو اقع الفعلي أـ الأسباب الدافعة للعداء و هيمنة الثقافة الامريكية، وتتمثل في:

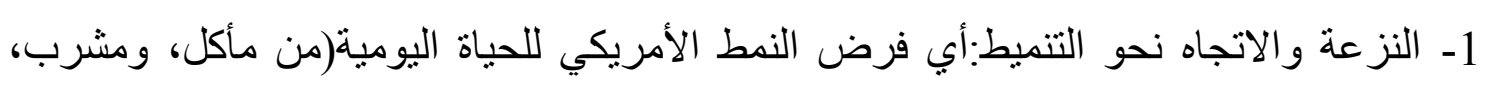

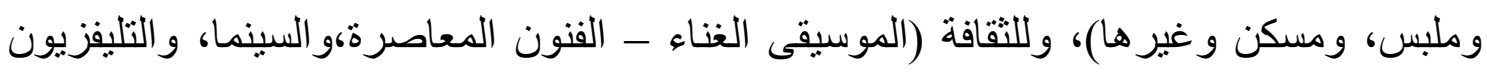

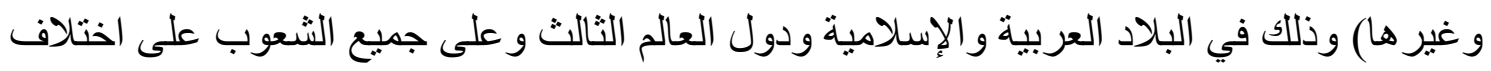

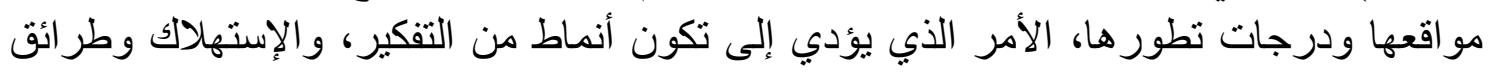

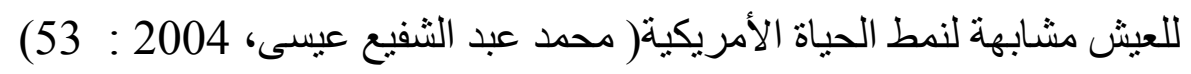


2- تهميش دور المؤسسات الدولية: ويتمثل باستغلال الولايات المتحدة الأمريكية لمنظمة الأمم

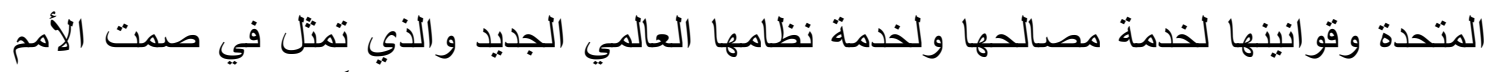

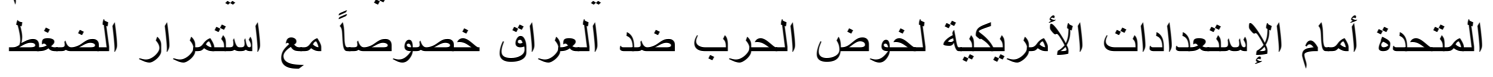

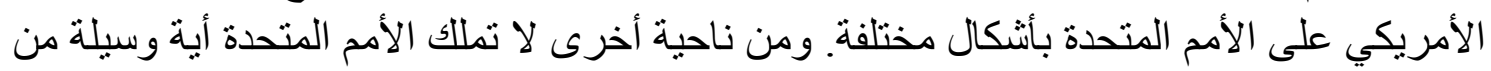

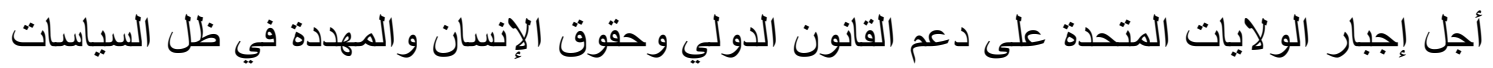

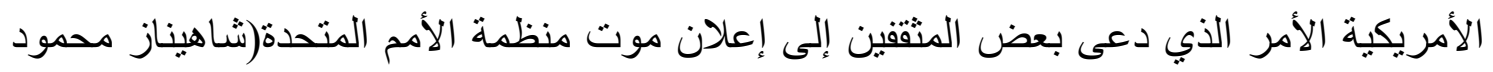

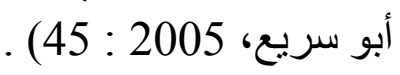

3- النزعة نحو السيطرة و الهيمنة: إن الو لايات المتحدة كانت تتوقع أن تصبح زعيمة النظام العالمي

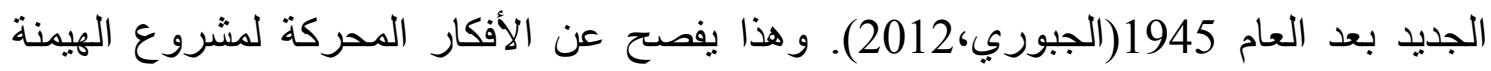

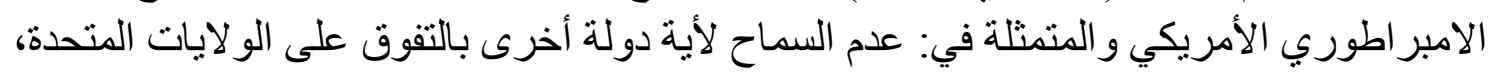

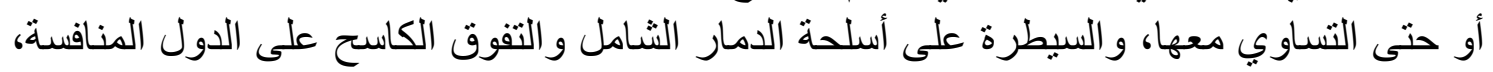

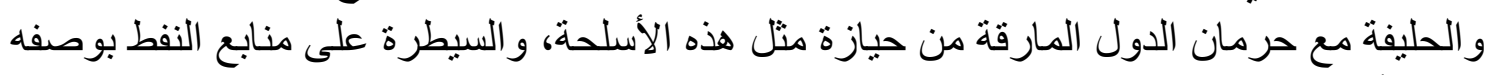

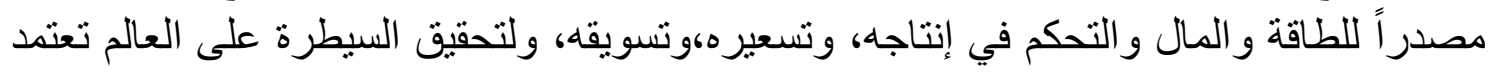

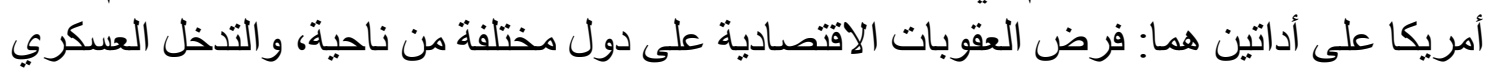

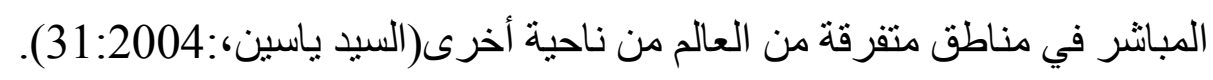

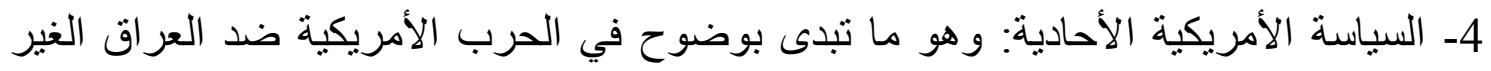

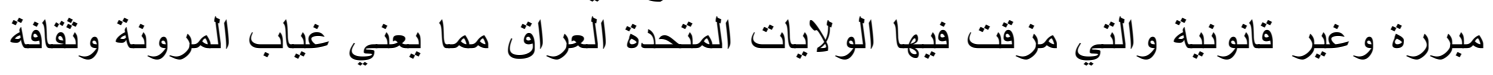

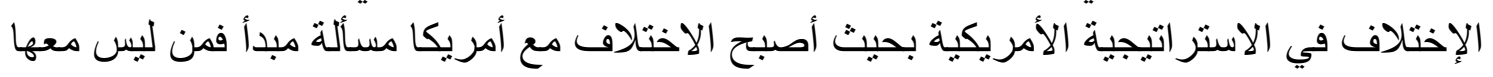

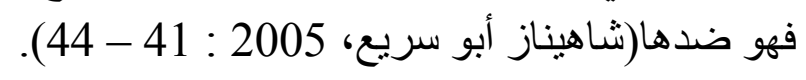

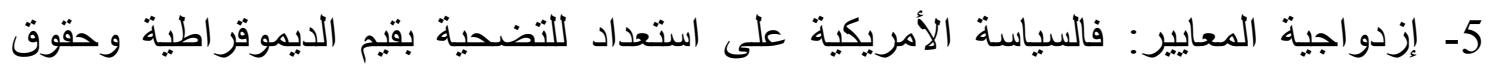

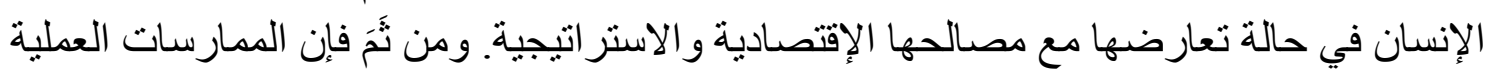
تعكس إزدو اجية في المعايير وقضية الديمقراطية وحقوق الانسان (حمدي عبد الرحمن، 2000 ،

( 11 -10

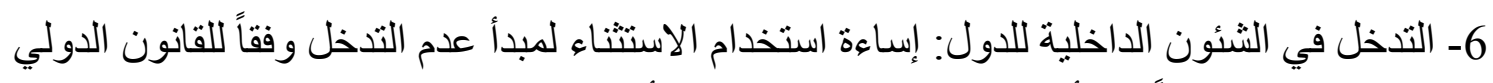

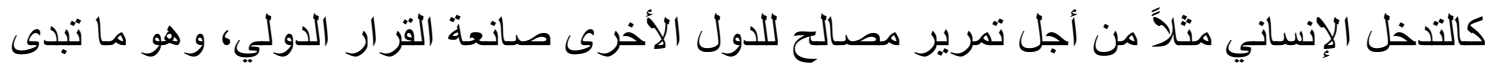

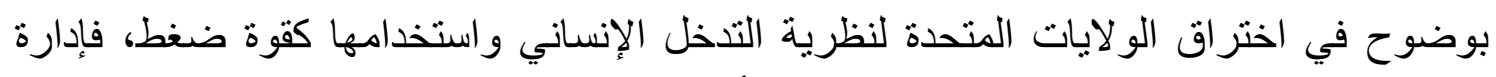

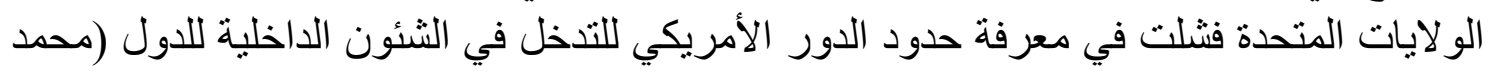
حيدر، 2001 : 42 - 44 ؛ شاهيناز أبو سريع، 2004 : 21 - 22) 
7- استراتيجية الحرب الإستباقية الأمريكية والحرب ضد الإرهاب: إعتماد فكرة الضربات أو

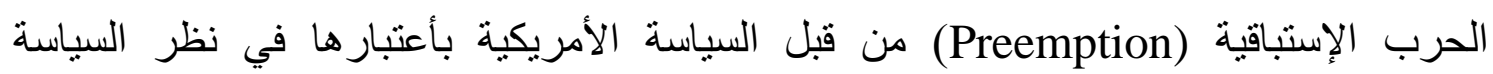
الأمريكية هي أنجح الاستراتيجيات العسكرية لمواجهة تهديدات الأمن القومي الأمريكي الجديدة لاعية الإنية

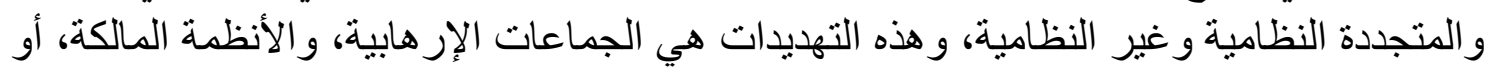

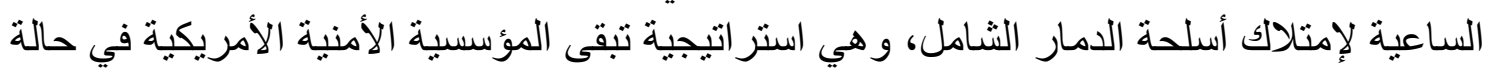

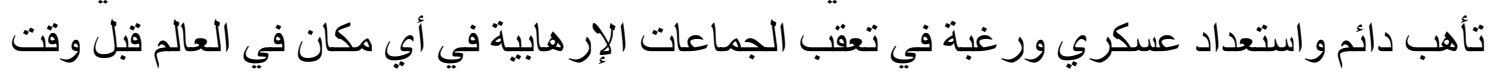

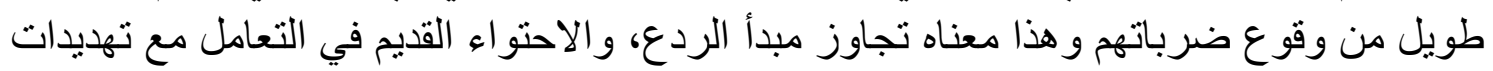
الأمن القومي الأمريكي(فرغلي هارون، 2006 : 172) ولقد تمثلت الاستر اتيجية الأمريكية لمكافحة الإرهاب في فرض مفهومها الخاص للإرهاب وجعله مفهوم عالمياً، ووحيداً تتساوى فيه الإنه المقاومة مع الإرهاب، وهو ما أعتبر مصدر الكر اهية والعداء نحو أمريكا.

بـ أدوار المثقف في مناهضة الهيمنة الثقافية الامريكية: هناك جملة من الأدوار المنوط بأدائها المثقفون في مناهضة الهيمنة الأمريكية وهي كالآئي:

1- تتوير المواطنين لمسؤولياتهم الثعبية: إن للمثقف دور أساسي في نشر الوعي والمعرفة والمساهمة في خدمة قضايا مجتمعه والإنسانية، وعن طريق ممارسة المثقفين لمسؤوليتهم الثعبية باكتشاف (وابتكار)

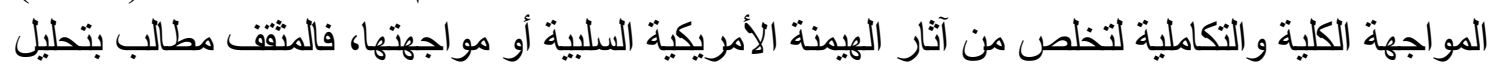

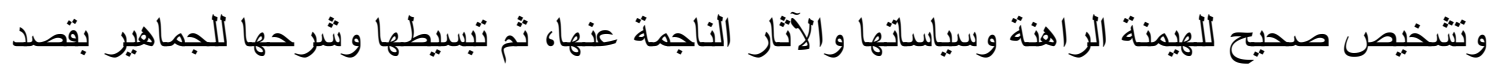

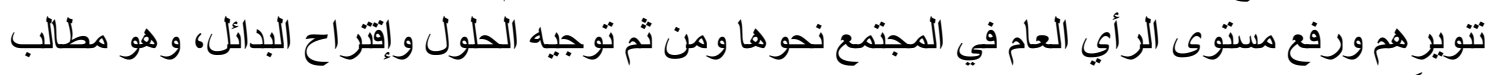
أيضاً بجانب ذلك توضيح لهم وإيجاد صلات بين مشكلاتهم وقضاياهم الجزئية دن ناحية، والإطار الكلي الأعم المتسبب في تلك المشكلات وفي أوضاعهم المتردية من ناحية أخرى، أب إن الدور المنوط به المثقفين هو تغيير الوضع القائم وتجاوزه.

2- نتر ثقافة الوعي الثعبي: وهي من الأدوار التي يتعين على المثقف القيام بها فالمثقف العراقي مُطالب التبات

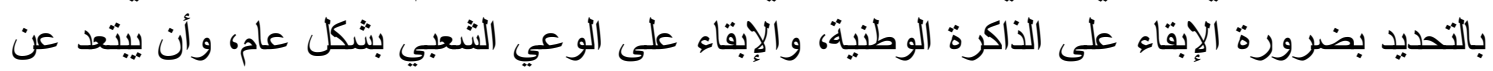

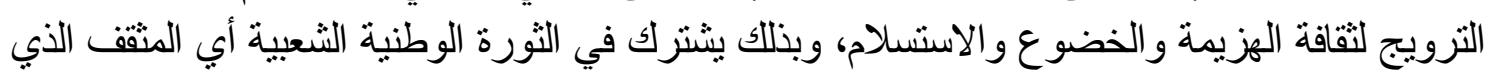
بمزج الوعي بالممارسة.

3- فتح الحوار أمام الجماهير للمشاركة في القضايا الوطنية: فالمثقف يرتكز دوره المحوري في فتح الحوار

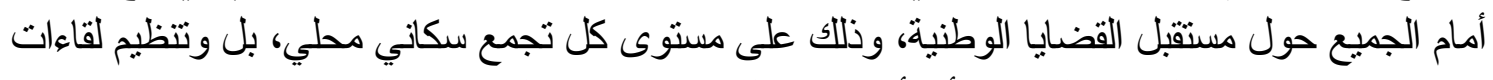
وفتح حوارات لثعبية لمناسبة للجميع، أب أن يعكس الخطاب المحلي للمطالب و القضايا الملموسة للجماهير.

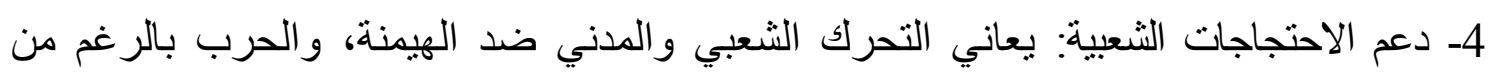

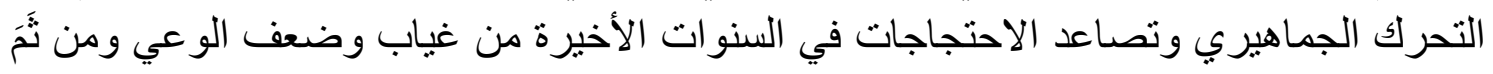




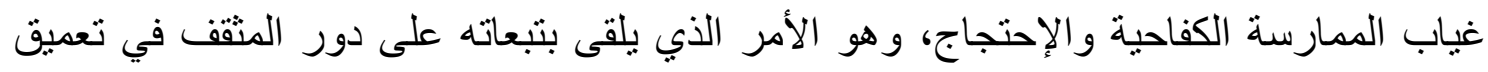

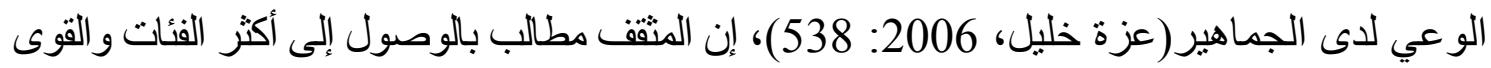

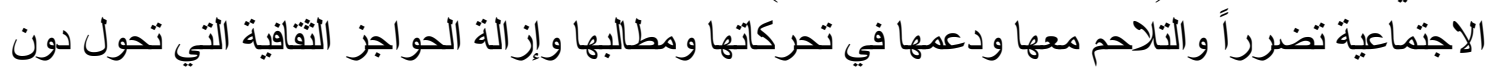

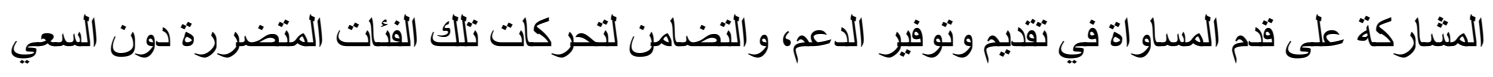

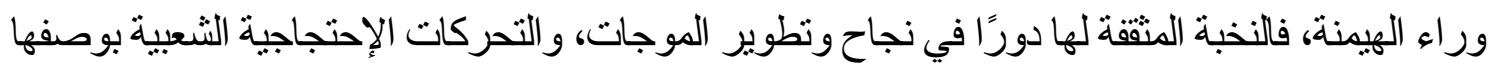

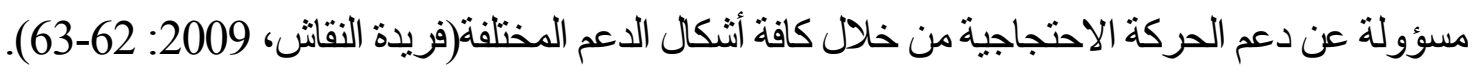

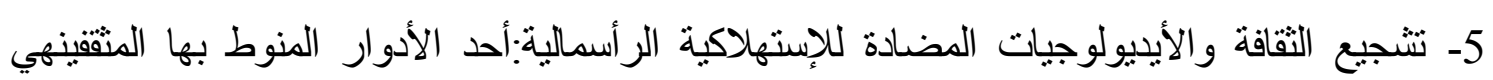

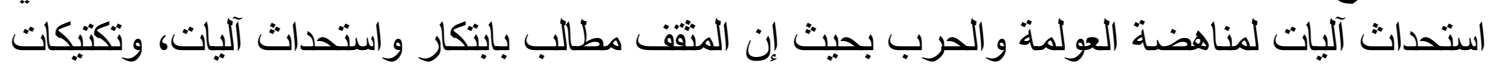

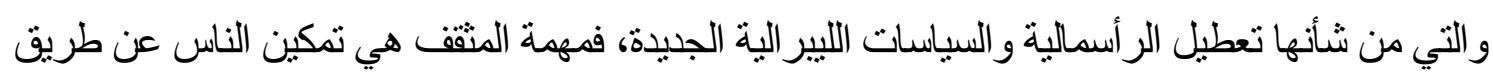

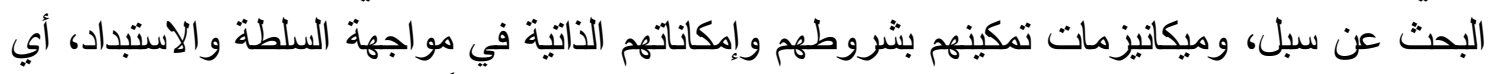

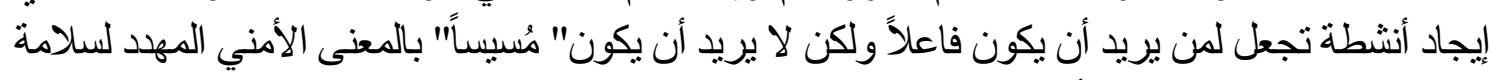

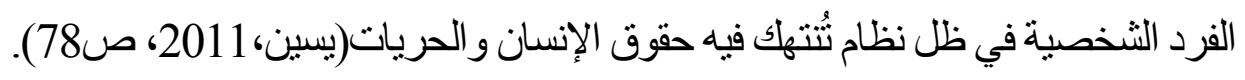

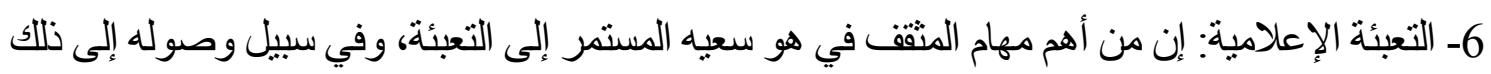

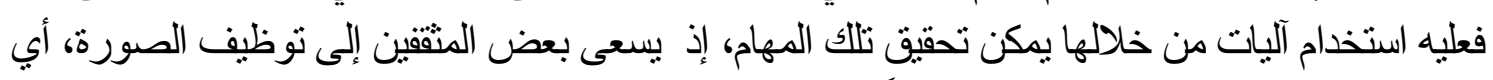

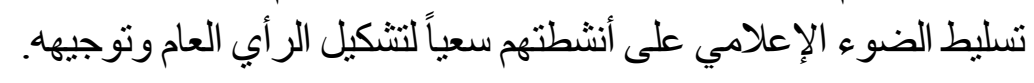
تـ المعوقات التي تقف عائقاً أمام المثقف العر اقي في مناهضة الهيمنة الأمريكية، وهي:

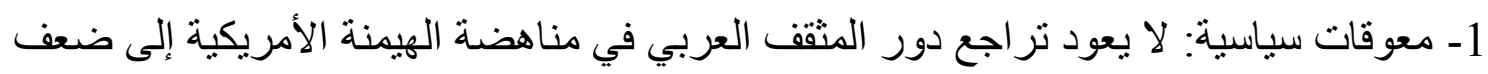

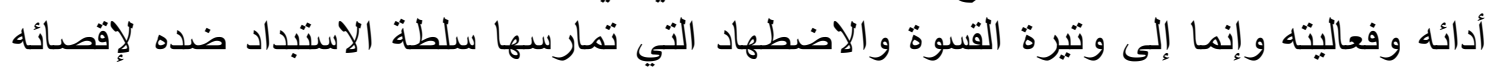

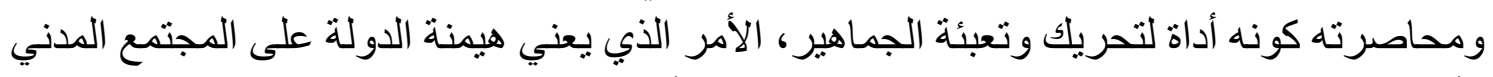

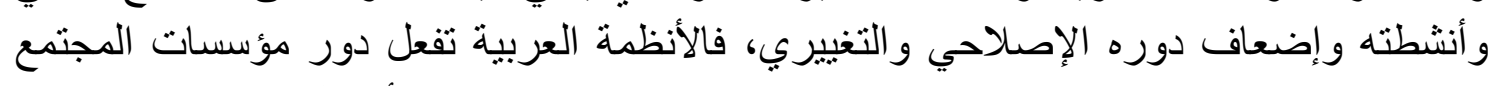

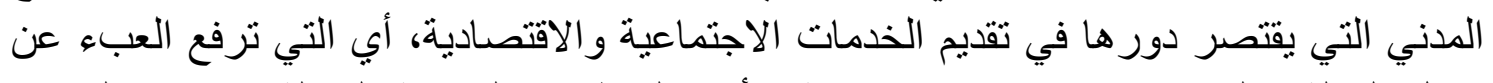

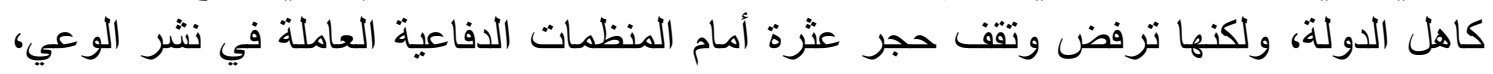

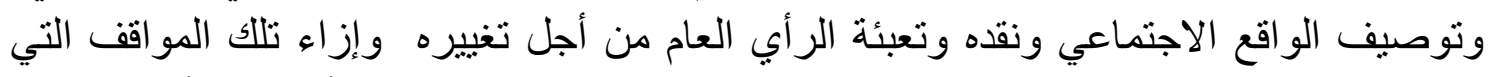

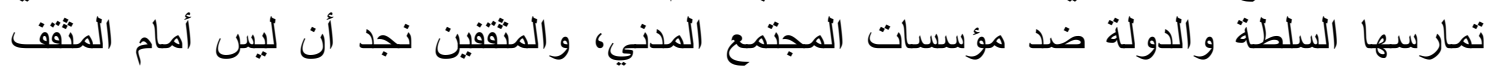

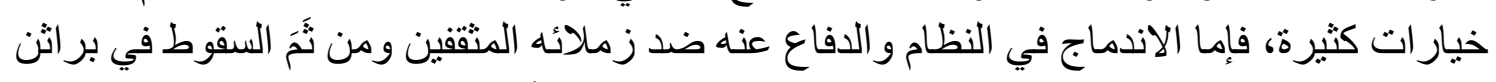

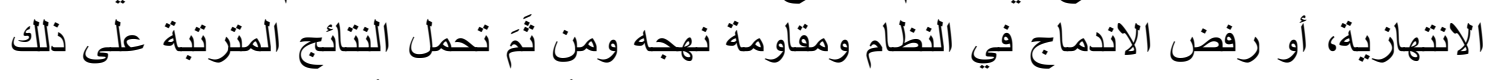

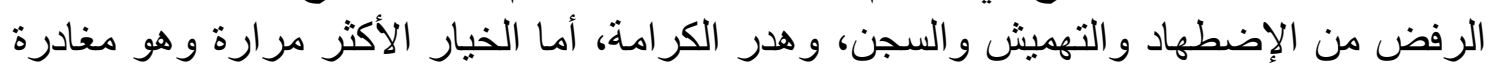

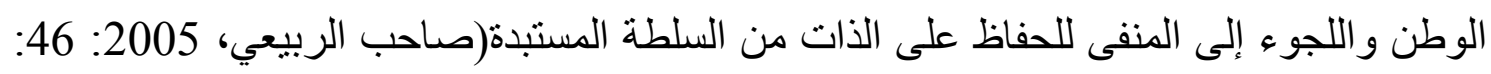


2- النخبوية: فالمثققين مطالبين بالتخلي عن موقف الإنعزال، والإنطواء، والدخول في ساحة

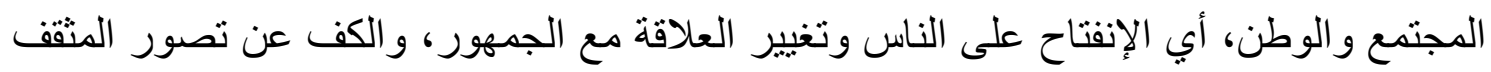

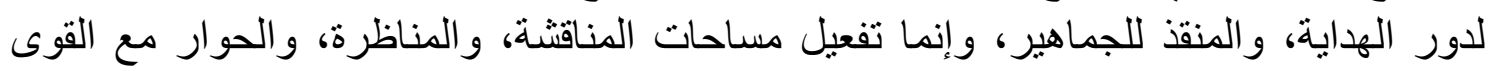

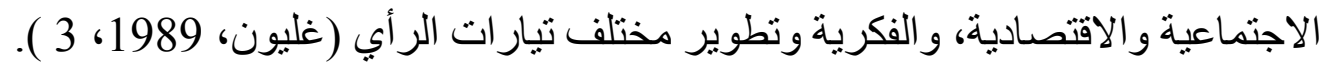

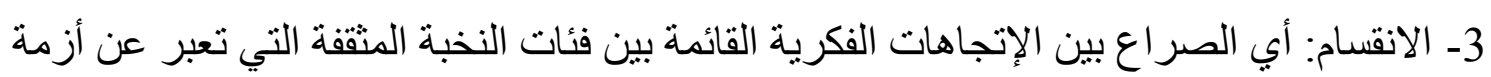

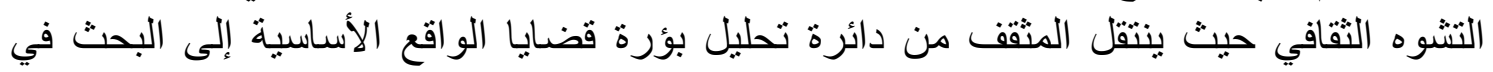

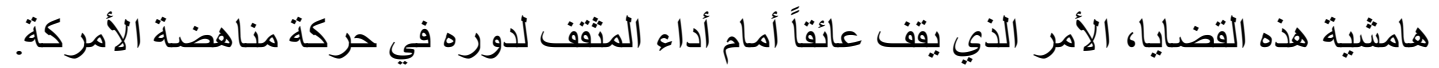

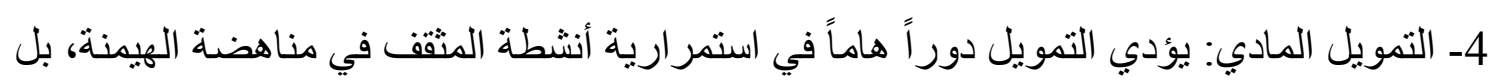

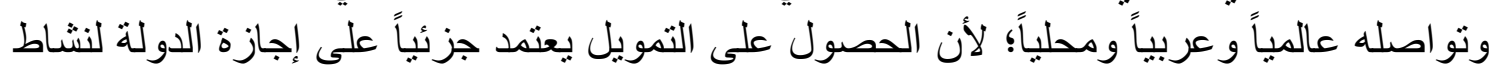

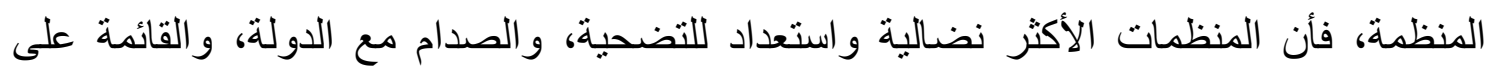

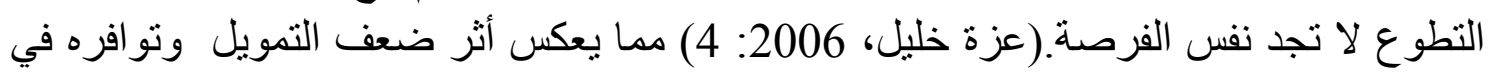
إستمرارية وتتوع أنثطة المثقف العر اقي في مناهضة الهيمنة الألمريكة الهريكية على المستوى العالمي و المحلي. المبحث الربع: الإجر اءات المنهجية للار اسة أولاً: منهجية البحث

1- أسلوب الدراسة: اعتمد الباحث على الأسلوب الوصفي، ويتم استخدام طرق متتوعة في إطار

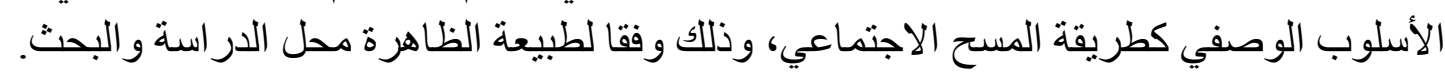

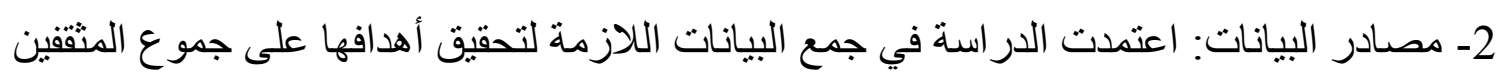

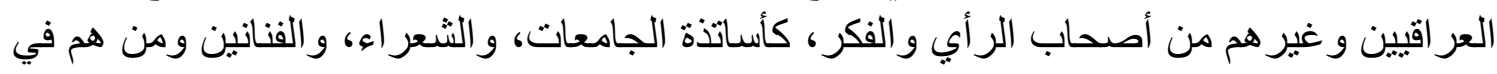
حكمه( أصحاب القلم والر أي )، ويمثل هؤلاء الأفر اد مجتمع البحث العام العام للار اسة.

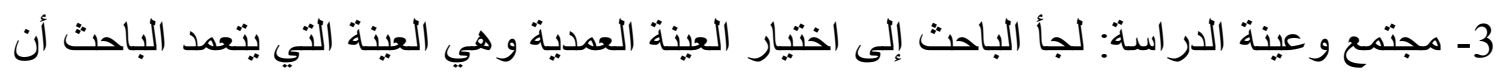

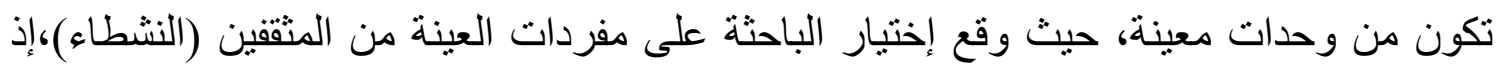

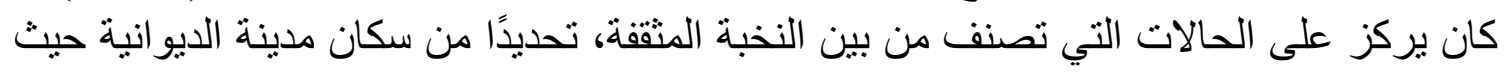

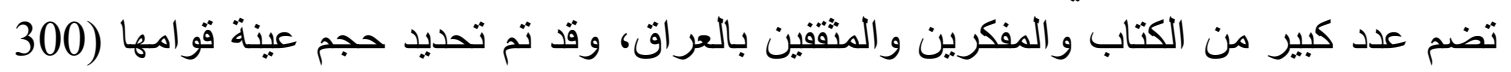

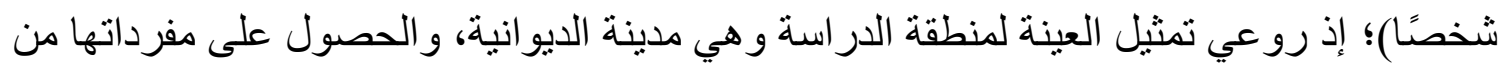

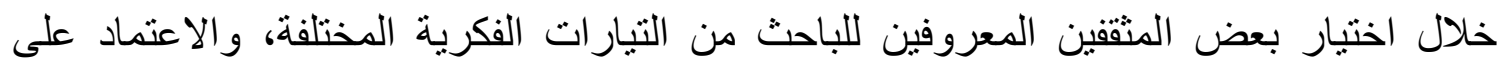

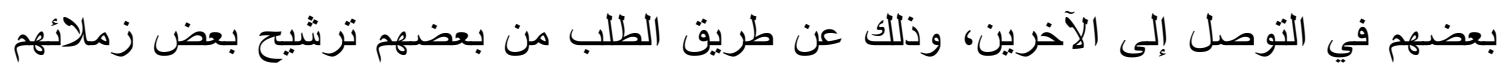
للباحث، وأخذ عناو ينهم أو الاتصال بهر، أو إرسال أداة الاستبيان إليهم للإجابة عن تنساؤ لاتها. 
في ضوء موضوع الدر اسة الر اهنة كان لز اماً على الباحث الاستعانة بمناهج ملائمة لمعالجة الأبعاد

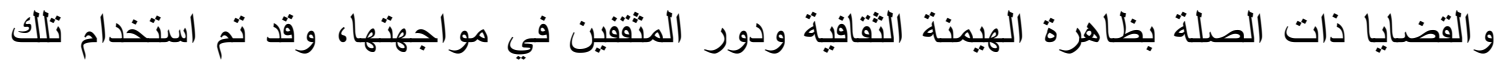
المناهج لتوفير البيانات لخدة البحث، ولربط الحاضر بالماضي، وتصنيف الحفة الحقائق، والبيانات، وتحليلها ثم استخلاص النتائج وتعميمها. و هي:

أـالمنهج التاريخي: يعد المنهج التاريخي الأسلوب الرئيس القادر على اكتشاف أعماق الظاهرة

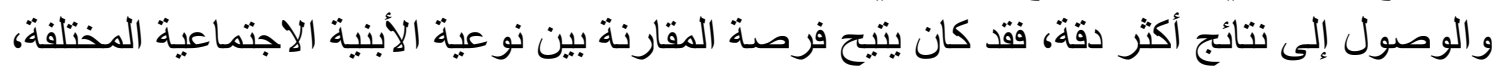

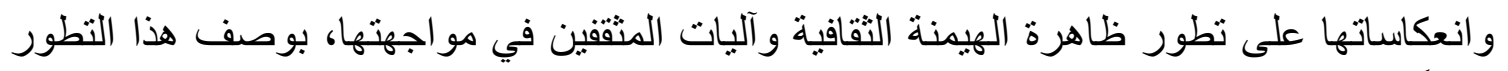
نتاجاً للبنية الطبقية في كل مرحلة تاريخية.

بـالمنهج الوصفي:وظفت هذه الدراسة المنهج الوصفي الذي يستهدف جمع بيانات كمية عن

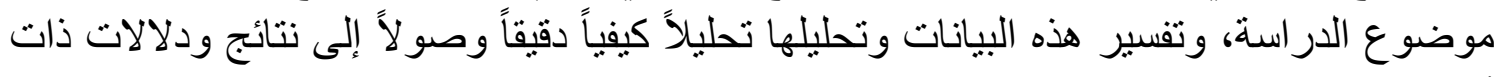
أهمية عملية من خلال الاستمارة المعدة لذلك.

5- أدو ات البحث: لتحقيق أهداف البحث اقتصرت الدراسة على أداة المسح (الاستبيان)، في جمع الحقائق و البيانات.وقد التوت لتوت استمارة الاستبيان على:

أ_البيانات الثخصيةَ تضمنت سن المبحوث، والنوع، و الحالة الزواجية، و الحالة التعليمية، ونوع المهنة.

ب-مقياس اتجاهات المثقفين حول الهيمنة الثقافية الأمريكية يتضمن إدراك المثقفين للعو امل الداخلية

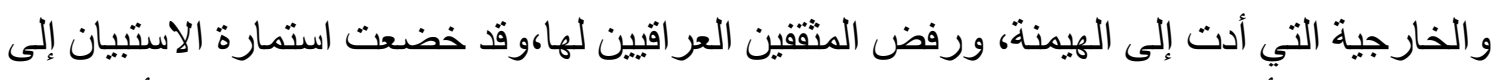
قياس صدق الأداةوثباتها،يقصد بثبات المقياس، إنه إذا كررنا تطبيق المقياس على نفس الأفراد فإننا

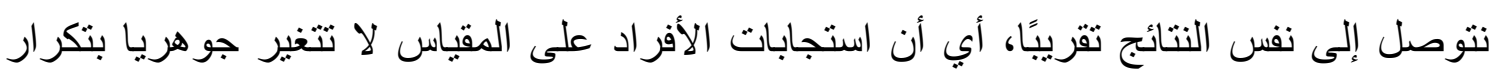

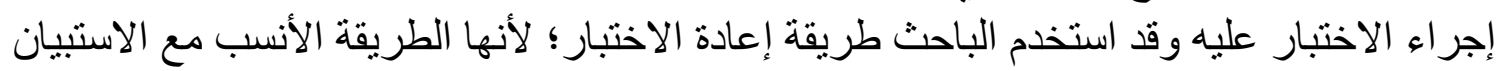

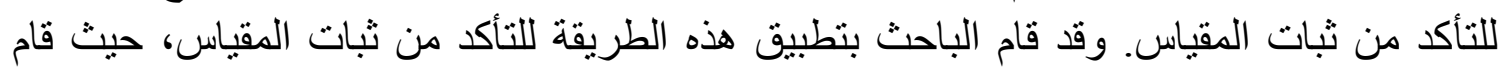

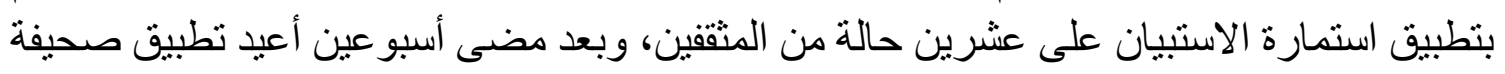

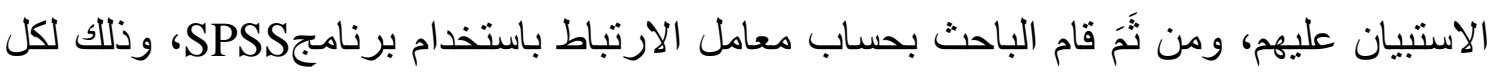
سؤ ال من أسئلة استمارة الاستبيان، وقد بلغت فئن نتيجة الارتباط حو الي(78\%) تقريبًا لمعظم الأسئلة؛

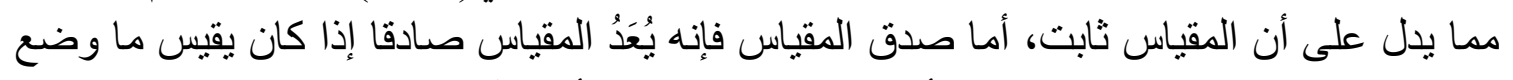

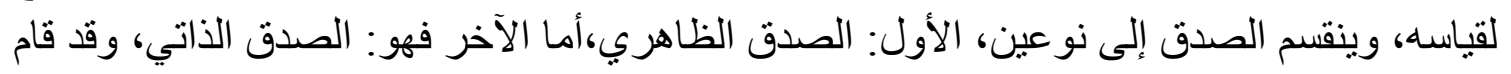

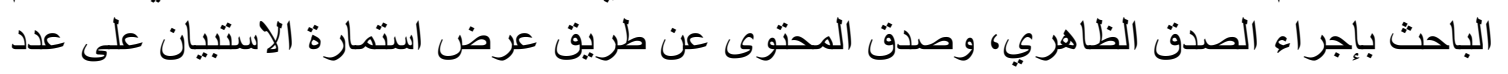

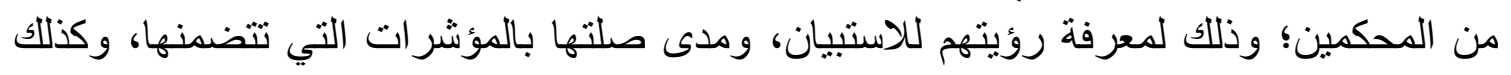


مدى وضوح العبار ات وسهولتها؛ وقد أفادت الباحث من ملاحظاتهم، واستبعد بعض العبار ات غير

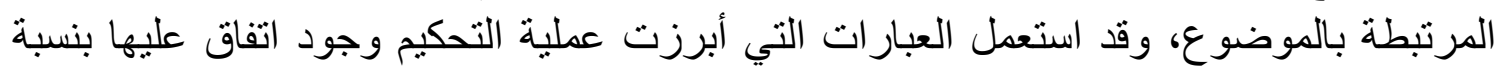
ثقة (95\%) فأكثر.

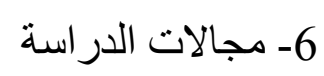

أـ المجال الجغر افي: ويتمثل المجال الجغر افي للار اسة في مجتمع محافظة الديو انية.

بـالمجال البشري: قد اختار الباحث صورة مصغرة لجمهور بحثه وقد ثَمَ اختياره في شكل عينة،

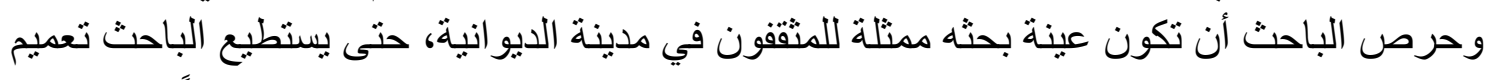

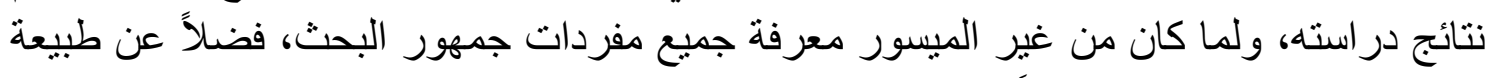

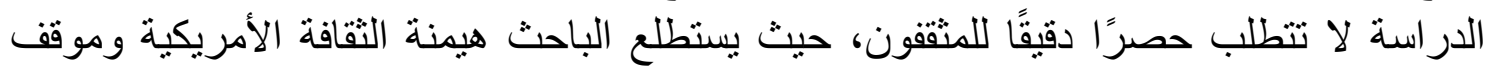

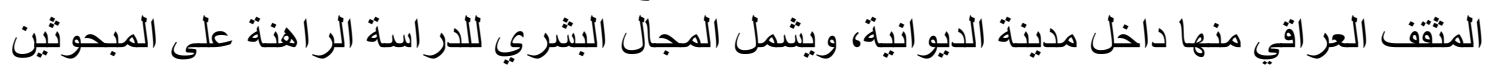
من الذكور، والإناث بمدينة الديوانية من النخبة المثقفة الذين يكونوا على دراية تامة بالأحداث الجارية في المجتمع العر اقي وما يرتبط بها في المجال الاقتصادي، و السياسي، و الثقافي. تـالمجال الزماني: المُدة الزمنية التي أجريت فيها الدراسة كانت محصورة بين (1-12-2012/ .(2013-2-1

7- خطة الدر اسة الميدانية وتحليل البيانات: بعد تحديد هدف الدراسة، ووضع المخطط المنهجي

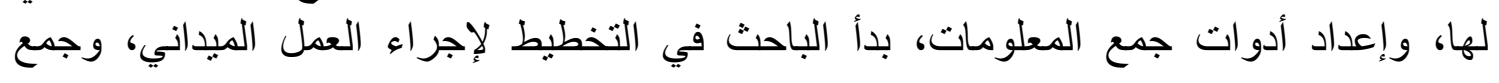

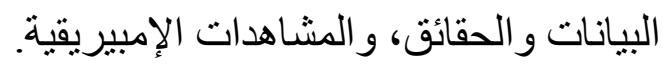

ثانياً: عرض نتائج الدر اسة الميدانية أ-خصائص عينة الدر اسة. الجدول رقم (1)يوضح خصائص عينة الدر اسة بحسب العمر

\begin{tabular}{|r|r|r|}
\hline أقلى من & العدر \\
\hline 4 & 12 & $40-30$ \\
\hline 40 & 120 & $50-40$ \\
\hline 36 & 108 & 50 \\
\hline
\end{tabular}




\begin{tabular}{|r|r|r|}
\hline 20 & 60 & $60-50$ \\
\hline 100 & 300 & المجموع \\
\hline
\end{tabular}

كثفت بيانات الجدول أعلاه نسبة توزيع العينة وفقا للعمر بحيث تبين أن الفئة العمرية المنحصرة ما بين(30) إلى(40) سنة هي الأكثر بين إجمالي العينة، و هي الفترة الثبابية، حيث وصلت ولتهن نسبتها

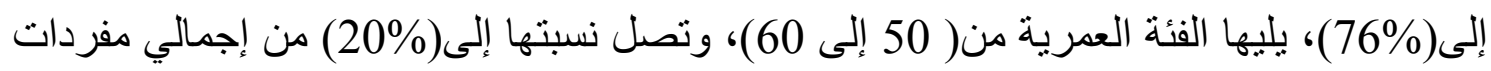

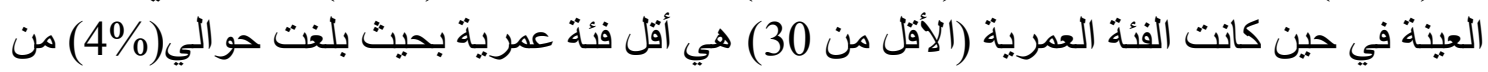
إجمإلى مفردات العينة. الجدول رقم ( 2 )يوضح خصائص العينة بحسب النوع

\begin{tabular}{|r|r|r|}
\hline ألنو & ألنوى \\
\hline 58 & 174 & ألنى \\
\hline 42 & 126 & المجموع \\
\hline 100 & 300 & \\
\hline
\end{tabular}

أوضحت بيانات الجدول أن نسبة الذكور أعلى من الإناث بحيث وصلت إلى (58\%)؛ في حين كانت نسبة الإناث

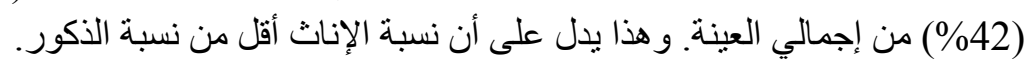
الجدول رقم (3)يوضح خصائص العينة بحسب الحالة الاجتماعية

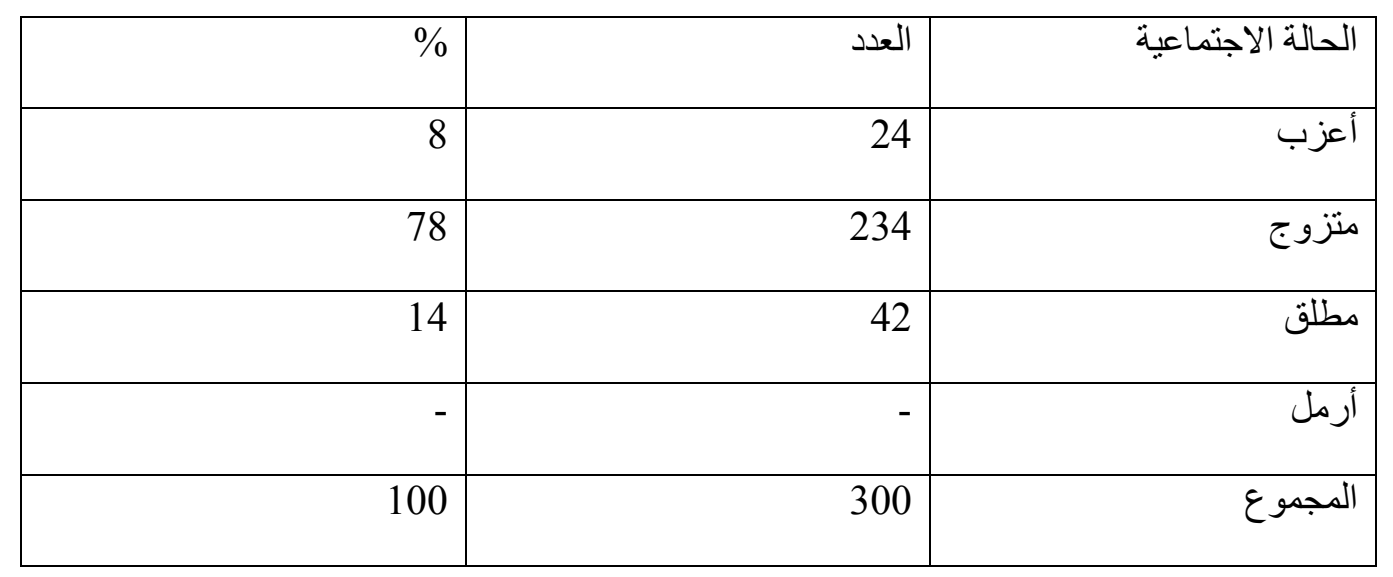




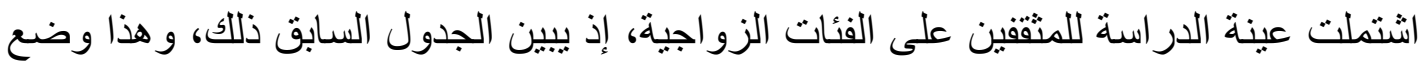
طبيعي، باعتبار أن مفردات مجتمع البحث من المثقفين تبدأ أعمار هم من(30) سنة، وبعد انتهن التهائهم

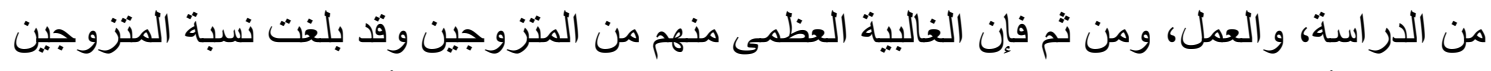
(78\%)، أما نسبة المطلقين فقد وصلت إلى (14\%) من إجمالي العينة، أما نسبة العز اب من عينة

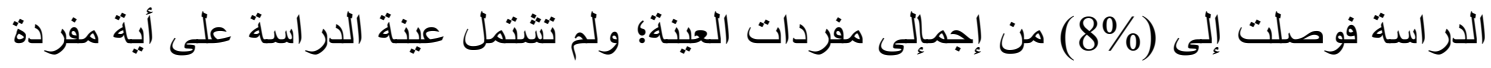
من الأر امل.

الجدول رقم (4)يوضح خصائص العينة بحسب الحالة التعليمية

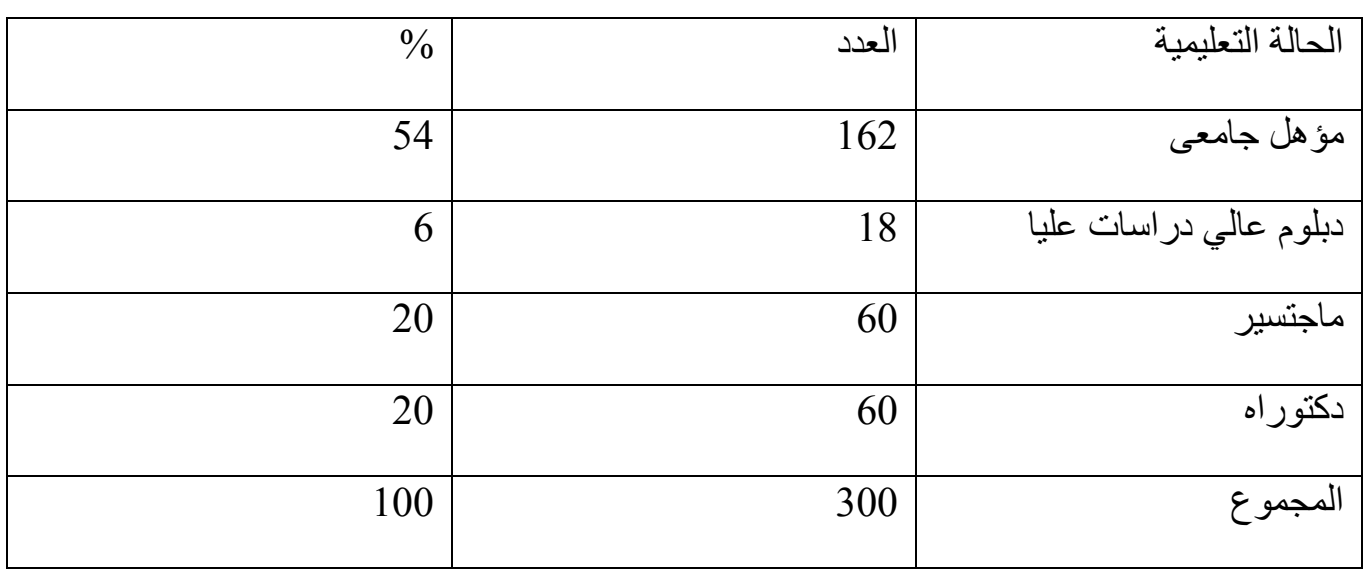

توز عت عينة الدر اسة على مختلف المستويات التعليمية إذ يكثف الجدول عن أن نسبة الحاصلين على مؤ هلات جامعية تمثل(54\%)، وهى أكبر نسبة موجودة؛ فى حين تتساوى النسبة في كل من

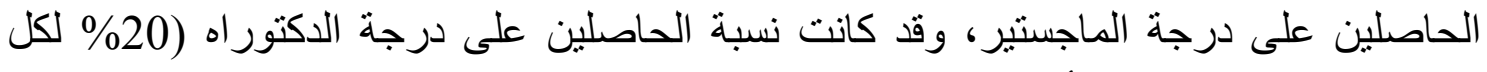

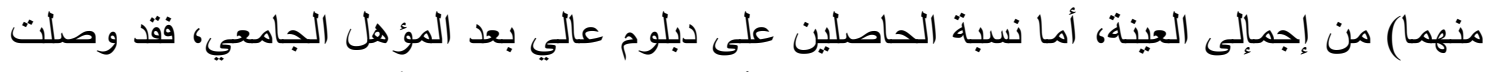

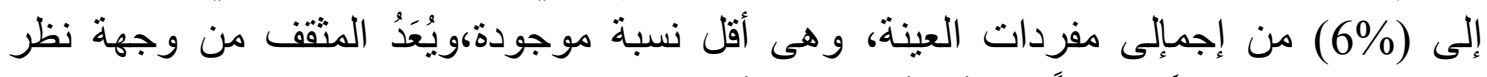

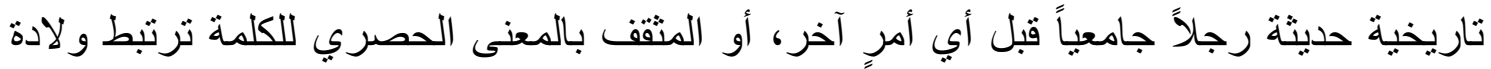

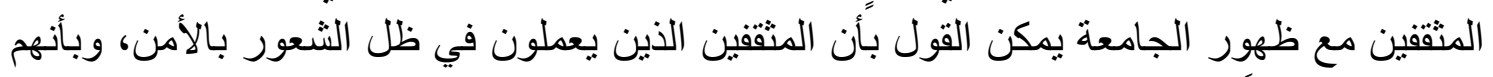

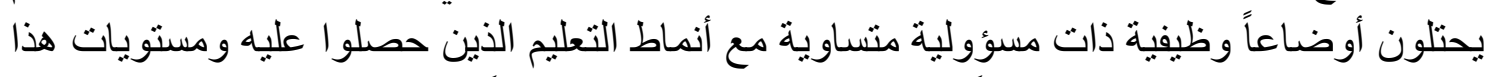

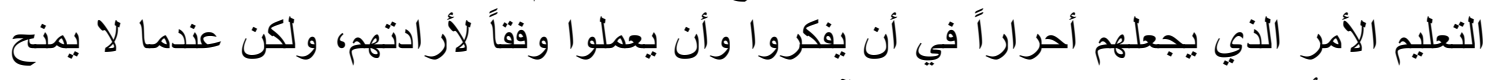

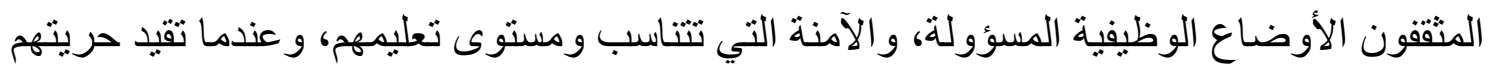
في التعبير والبحث. فعندئذ نتوقع من واقع هؤلاء المثقفين أن يظهر المتطرفون السياسيون. الجدول رقم (5)يوضح خصائص العينة بحسب المهنة 


\begin{tabular}{|c|c|c|}
\hline$\%$ & العدد & المهنة \\
\hline 46,4 & 139 & أستاذ جامعى \\
\hline 21,4 & 64 & إعلاميين \\
\hline 9 & 27 & كتاب - فنانين تشكلين \\
\hline 10 & 30 & أطباء \\
\hline 1,6 & 5 & من دون وظيفة \\
\hline 100 & 300 & المجموع \\
\hline
\end{tabular}

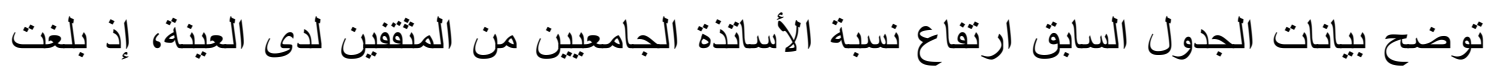
نسبتهم (46,4\%) من إجمالى العينة في حين وصلت نسبة الإعلامبين العاملين في مجالات الصحافة والإذاعة و التليفزيون من المثقفين إلى(21,4\%) من إجمالى العينة، أما النقاد، و الكتاب، و الفنانون فقد بلغت نسبتهم حوالي (11,6\%) من إجمالى مفردات العينة في حين بلغت نسبة الأطباء من المثقفين حوالي(10\%) من إجمالى مفرادات العينة كما بلغت نسبة المحامين من

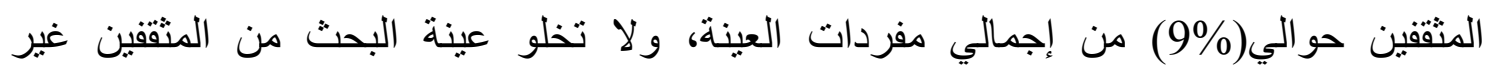
المرتبطين بعمل محدد (عمل حر)، حيث تبين وجود(1,6\%) من بين مفردات العينة.ويحدد الباحث

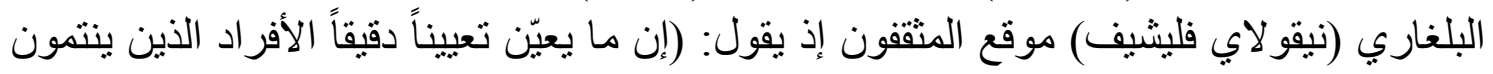

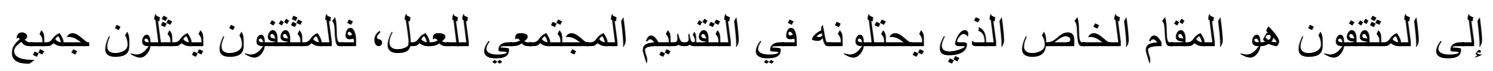

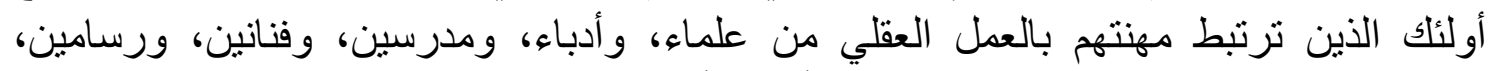

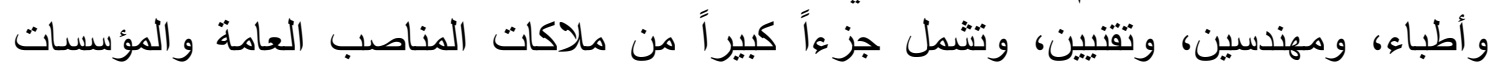

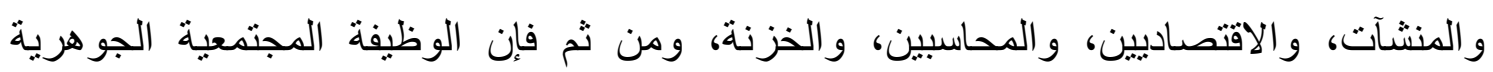

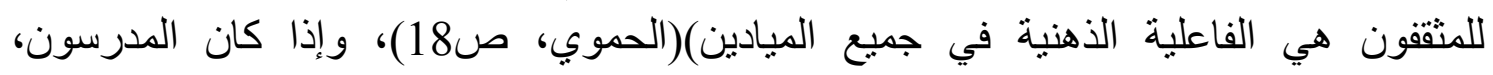

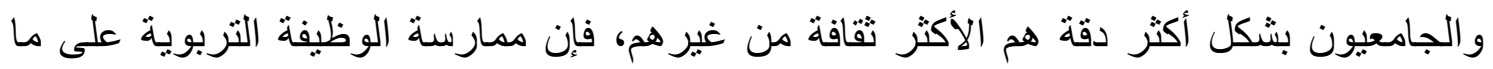

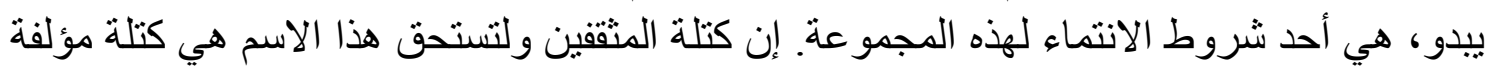

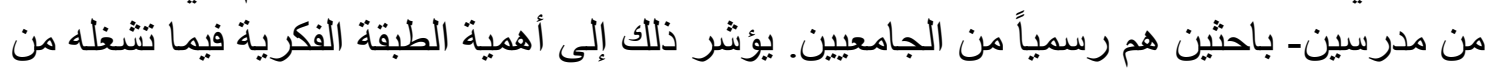

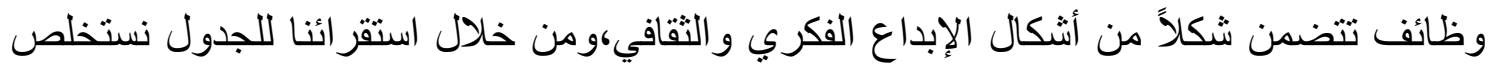
أن عينة الدراسة تحوي نسبة عالية من ذوي الخبرة التعليمية و الثقافية الو اسعة.

ب-مقياس اتجاهات المثققين حول الهيمنة الثقافية الامريكية 
5-مظاهر الهيمنة الأمريكية في الحياة اليومية من وجهة نظرعينة الدر اسة: الجدول رقم(6) يبين مظاهر الهيمنة الثقافية من وجهة نظر أفر اد عينة الدراسة

\begin{tabular}{|c|c|c|c|c|}
\hline التسلسل المرتبي & $\%$ & العدد & الفقرة & ت \\
\hline 4 & 31,30 & 67 & الهيمنة العسكرية & 1 \\
\hline 2 & 77,57 & 166 & سيطرة النموذج الغربي على الحياة الاجتماعية & 2 \\
\hline 3 & 41,58 & 89 & المساعدات و المنح الامريكية للدول العربية & 3 \\
\hline 7 & 21,49 & 46 & وجود شبكة الانترنيت & 4 \\
\hline 1 & 93,92 & 201 & العولمة & 5 \\
\hline 6 & 27,57 & 59 & السيطرة العسكرية على بعض دول العالم العربي و الاسلامي & 6 \\
\hline 5 & 33,17 & 71 & الحروب الداخلية العر اقية مع بعض دول المنطقة & 7 \\
\hline
\end{tabular}

يتضح لنا من الجدول رقم(6) أن العولمة، وسيطرة النموذج الغربي على الحياة الاجتماعية،

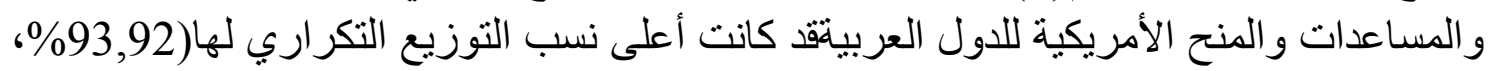
\%77,57، \%1,58\%)، ثم نأتي الحروب الداخلية العراقية مع بعض دول المنطقة، والسيطرة

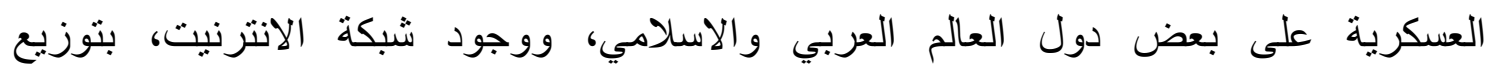

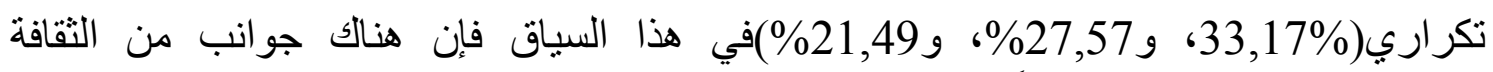

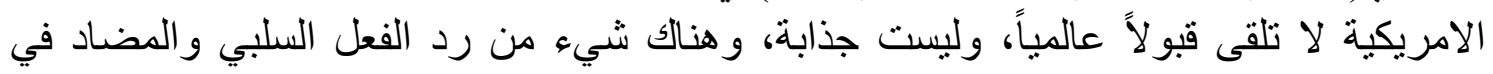

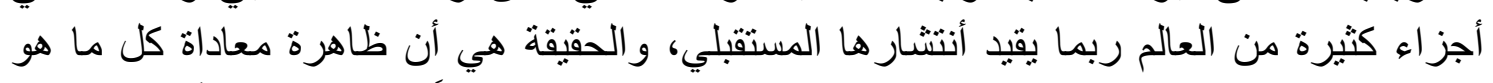

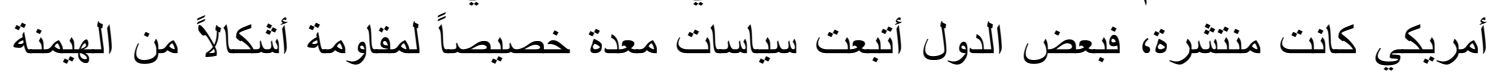

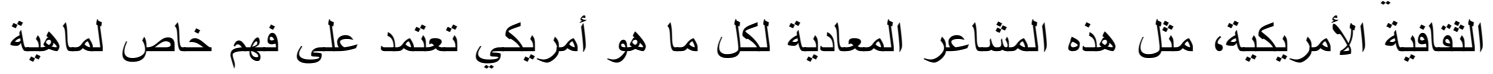

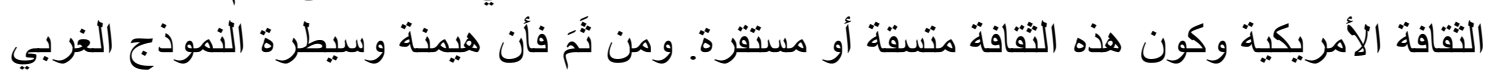

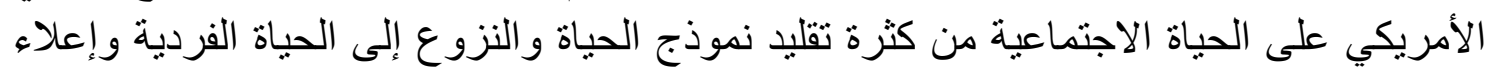

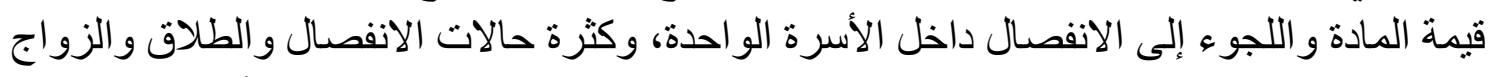

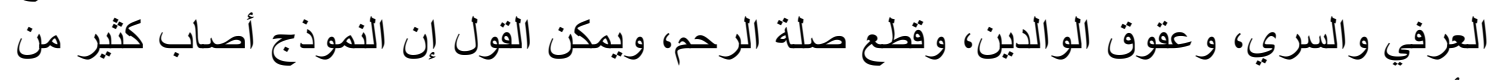
الأسر ، ولكن يوجد البعض الذي لا يزال متمسك بصلة الرحم، وطاعة الو الدين.

6-أنواع هيمنة الثقافة الامريكية في الحياة الاجتماعية العر اقية، من وجهة افر اد عينة الدراسة: الجدول رقم(7) يبين أنواع الهيمنة الامريكية من وجهة نظر افراد عينة الدر اسة 


\begin{tabular}{|c|c|c|c|c|}
\hline التسلسل المرتبي & $\%$ & العدد & الفقرة & ت \\
\hline 3 & 61 & 183 & الهيمنة العسكرية & 1 \\
\hline 2 & 70,33 & 211 & الهيمنة الثقافية & 2 \\
\hline 5 & 29,66 & 89 & الهيمنة السياسية & 3 \\
\hline 4 & 33 & 99 & الهيمنة التكنولوجية & 4 \\
\hline 1 & 92,66 & 278 & الهيمنة الامنية & 5 \\
\hline 6 & 27,33 & 82 & الهيمنة الاعلامية & 6 \\
\hline
\end{tabular}

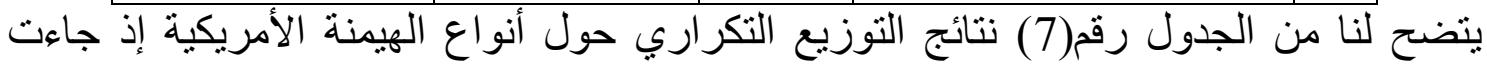
الهيمنة الامنية والثقافية والعسكرية والتكنولوجية والسياسية والاعلامية كأعلى أهم أنواع الهيمنة

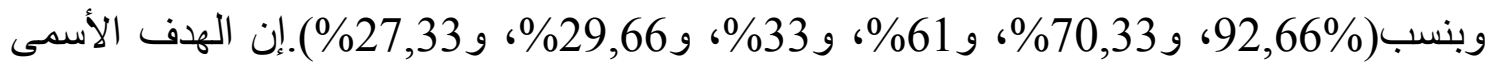

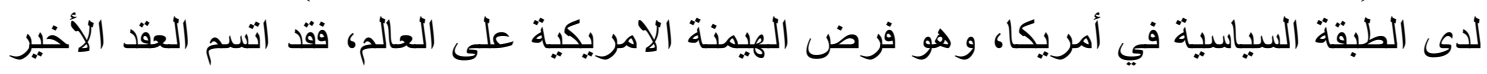

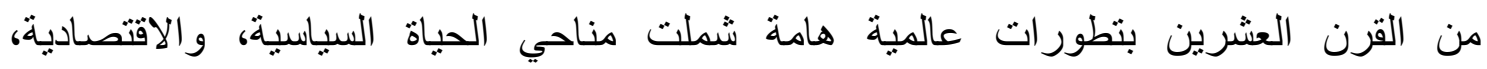

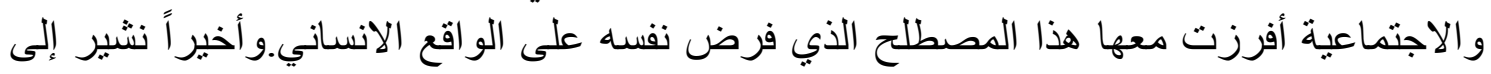

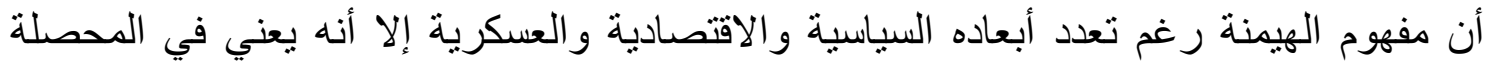

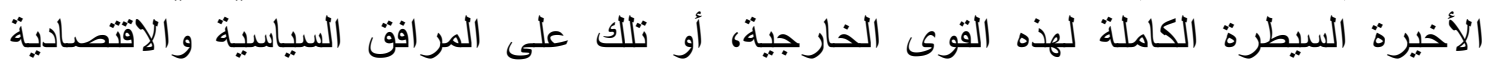

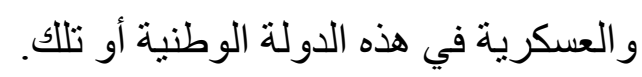

7-أسباب السيطرة الأمريكية علسالمجتمع العر اقي بسبب الثروات طبيعية هو السبب في السعي نحو

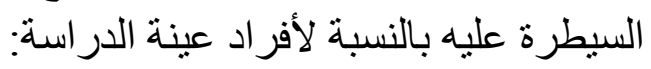

جدول رقم (8) يبين أسباب السيطرة الامريكية على المجتمع العر اقي بسبب الثروات طبيعية لأفر اد عينة الدراسة جدو

\begin{tabular}{|r|r|r|}
\hline$\%$ & نعد العدابة & \\
\hline 94,3 & 283 & العدم \\
\hline 5,7 & 17 & المجوع \\
\hline 100 & 300 & \\
\hline
\end{tabular}

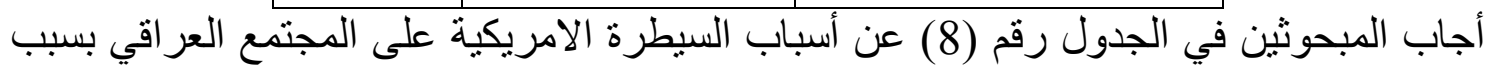

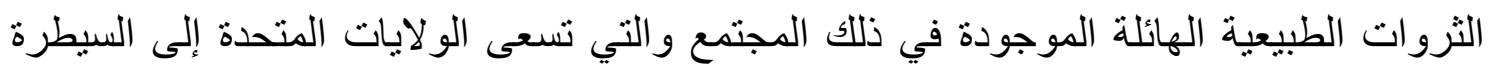


عليه، فقد كانت الإجابة كما يلي: مانسبته(94,3\%) أشر نعم، وبنسبة(5,7\%) اشر لا، فيما اشر

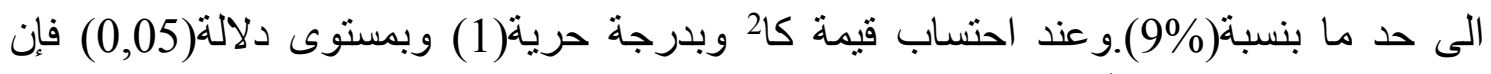

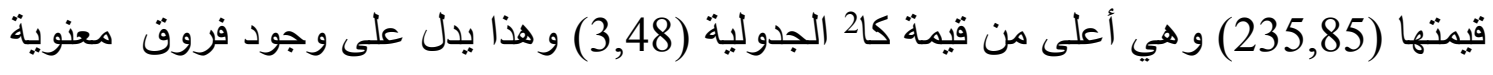

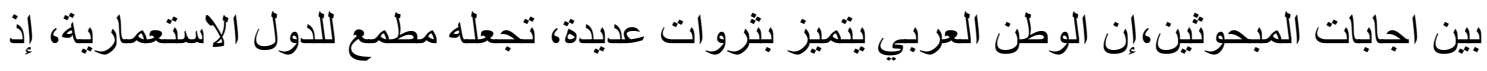

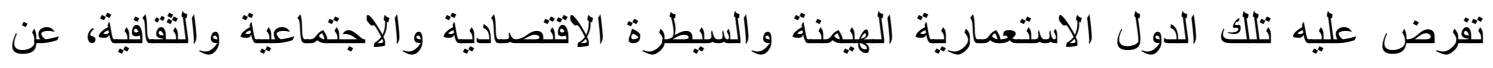

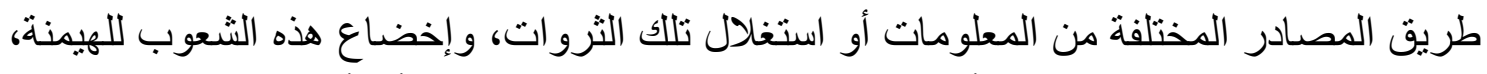
و هذا يدل على نسبة الاتفاق بين أفراد عينة الدراسة من المثقفين على أن أهم الثروات التهن التي تمديز البلاد العربية و التي قد تجعل الو لايات المتحدة أكثر قرباً من تلك الدول التئ التي توجد بها تللك الثروات.

8-أسباب ظهور ثقافة القطب الأوحد بسبب السياسة الاقتصادية للو لايات المتحدة الامريكية: الجدول رقم(9) يبين ظهور ثقافة القطب الأوحد بسبب السياسة الاقتصادية للو لايات المتحدة

\begin{tabular}{|c|c|c|c|c|}
\hline الوزن الرياضي & $\%$ & العدد & الاسباب & $ت$ \\
\hline 1 & 39,7 & 119 & نعم & 1 \\
\hline 2 & 37,7 & 113 & إلى حد ما & 2 \\
\hline 3 & 22,6 & 68 & $y$ & 3 \\
\hline & 100 & 300 & المجموع & \\
\hline
\end{tabular}

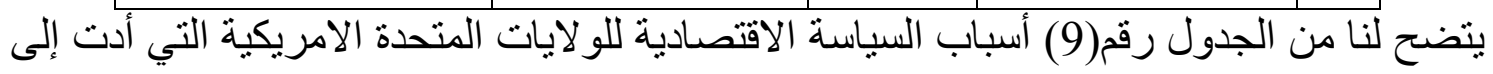
ظهور ثقافة القطب الأوحد، وكانت أغلب اجابات المبحوثين بـ(نعم) (39,7\%)، و(إلى حد مال)

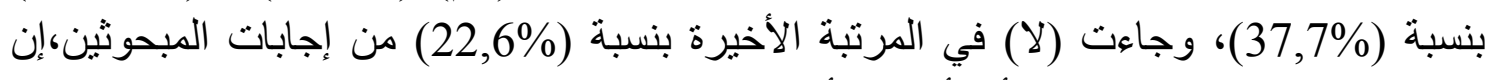

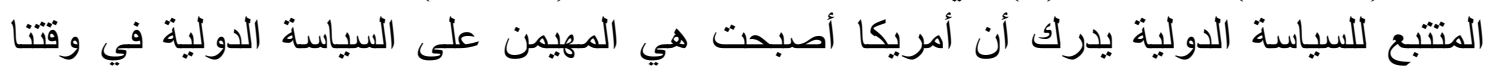

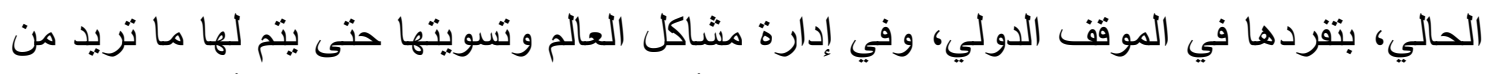

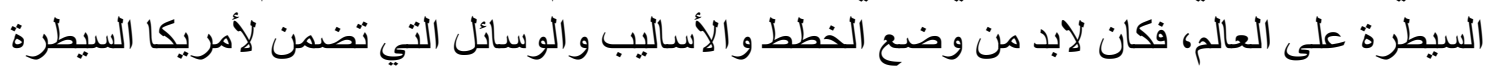
و الانفر اد بوصفها قوة واحدة في العالم، فضلاً عن نشر مفاهيم وقناعات المبدأ الر أسمالي في العالم.

9-للمثقف دور أساس في حماية أصول الثقافة العربية وحماية النشيء من الوقوع في سلبيات الثقافة الغربية

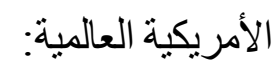

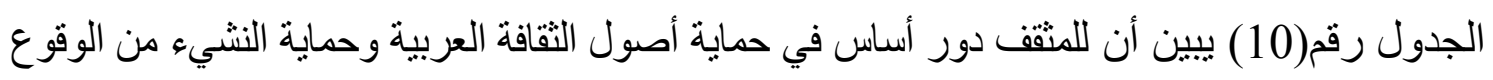

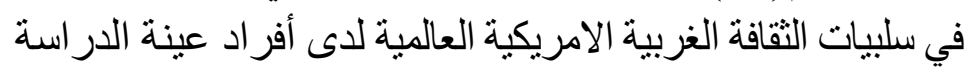




\begin{tabular}{|c|c|c|c|}
\hline التسلسل المرتبي & $\%$ & 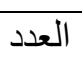 & 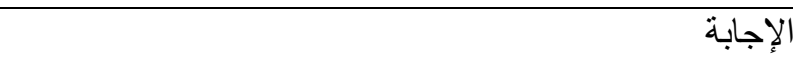 \\
\hline 1 & 89 & 267 & التوجيه يأخذ المفيد منها كي يقق على مر احل التقدم \\
\hline 2 & 65,66 & 197 & عدمالأخذ من سلبيات العولمة الثقافة الغربية الامريكية \\
\hline 3 & 26 & 78 & ومن وسائل الإعلام التي تساهم في عملية التنشئة الاجتماعية للنشيء \\
\hline & 100 & 300 & 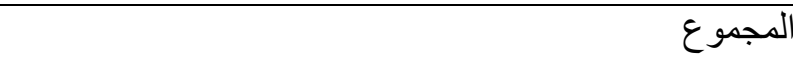 \\
\hline
\end{tabular}

كانت أكثر إجابات المبحوثين في الجدول رقم (10) أشرت (نعم) بنسبة(89\%) وهي الغالبية

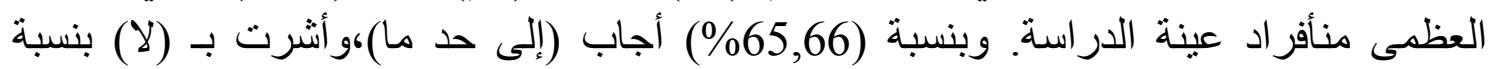

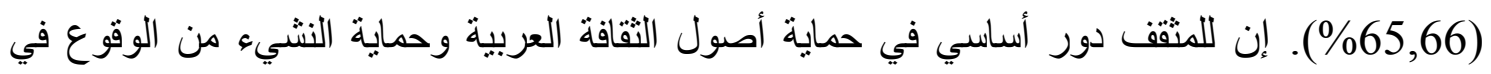

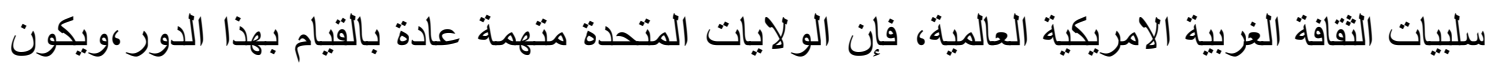
التوجيه يأخذ المفبد منها كي يقف على مراحل التقدم، وعدمالاخذ من سلبيات العولمة الثقافة الغربية الأمريكية، ومن وسائل الاعلام التي تساهم في عملية التنشئة الاجتماعية للنشيء. 10-اتباع نموذج الحياة الأمريكية في العراق لظهور الولايات المتحدة بالقوة الاقتصادية، و السياسية:

الجدول رقم(11) يبين اتباع نموذج الحياة الامريكية لظهور ها بالقوة الاقتصادية و السياسية

\begin{tabular}{|c|c|c|c|c|}
\hline التسلسل المرتبي & النسبة المئوية & التكر ار & الإجابة & ت \\
\hline 3 & 59,37 & 76 & إلى حد ما & 1 \\
\hline 1 & 86,71 & 111 & نعم & 2 \\
\hline 2 & 74,21 & 95 & $\gamma$ & 3 \\
\hline
\end{tabular}

من خلال الجدول رقم(11) تظهر الولايات المتحدة بوصفها قوة اقتصادية وسياسية إلى اتباع

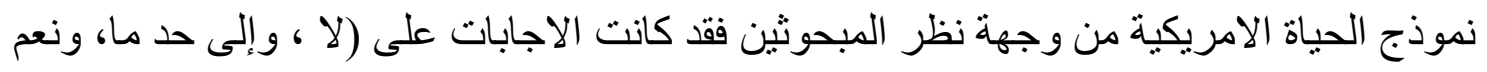

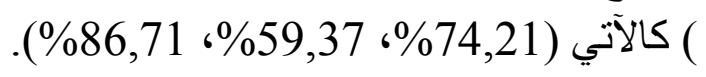

11 ـالمتقف مطالب بتتوير المواطنين وتأسيس و عي جديد خصوصاً للأجيال الجديدة التي تتعرض للتشويه و التضليل:

الجدول رقم(12) يبينمطالبة المثقف بتتوير المواطنين وتأسيس وعي جديد خصوصاً للأجيال الجديدة التي تتعرض للتشويه و التضليل 


\begin{tabular}{|r|r|r|}
\hline \% العدابة| & اللى حد ما \\
\hline 42,7 & 128 & \\
\hline 29,7 & 89 & \\
\hline 27,6 & 83 & \\
\hline 100 & 300 & المجموع \\
\hline
\end{tabular}

في الجدول رقم(12) يتبين أن المثقف مطالب بتتوير المو اطنين وتأسيس وعي جديد خصوصاً للأجيال

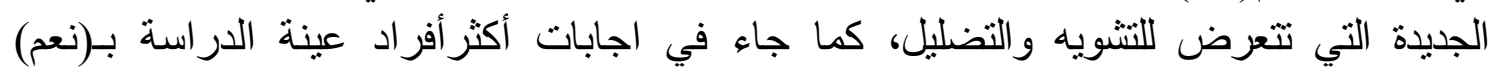

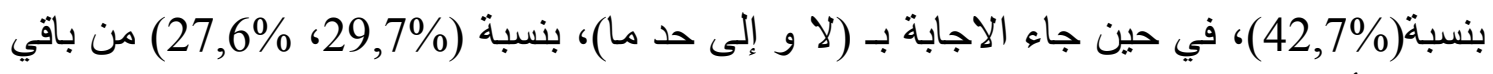

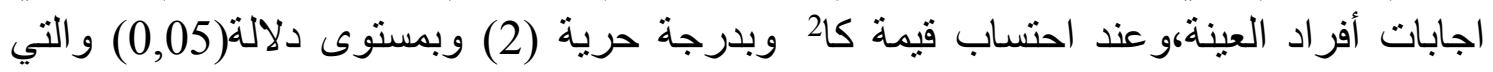

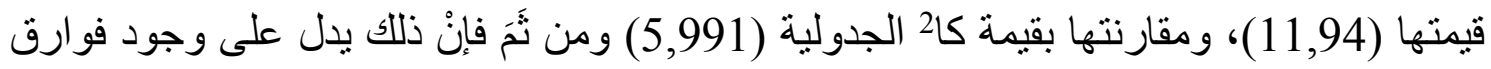
معنوية بين إجابات المبحوثين. 12-مهمة المثقفين هي مناقتشة وفضح أساليب الهيمنة التي تُمارس في جميع صيغها الاقتصادية، و السياسية، و العسكرية، و الثقافية:

الجدول رقم(13) يبين مهمة المنقفين هي مناقثة وفضح أساليب الهيمنة التي تُمارس في جميع صيغها

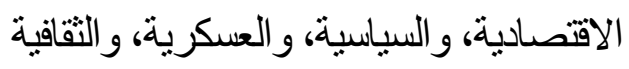

\begin{tabular}{|c|c|c|}
\hline$\%$ & العدد & الإحابة \\
\hline 29,7 & 89 & 20 \\
\hline 21,6 & 65 & إلى حد ما \\
\hline 48,7 & 146 & $y$ \\
\hline 100 & 300 & المجموع \\
\hline
\end{tabular}

يتبين من الجدول رقم(13) رأي عينة الدراسة بخصوص مهمة المثقفين هي مناقثة وفضح أساليب

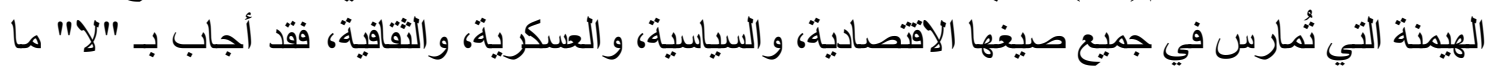

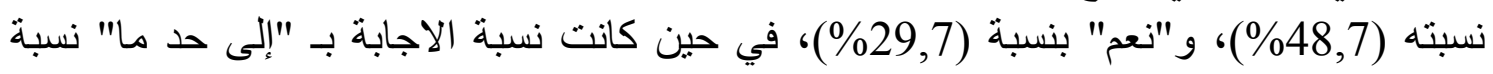

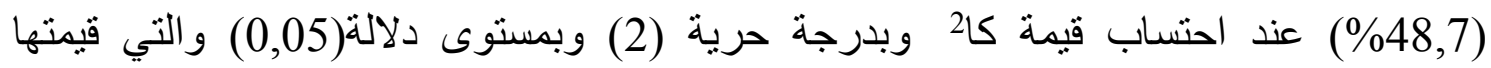

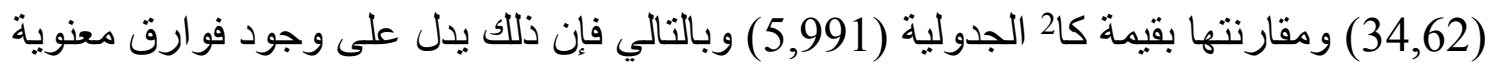
بين إجابات المبحوثين. 
13-المثقف مدعو إلى التصدي لكل الأفكار الخاطئة التي تروج بضرورة التأقلم مع العولمة الر اهنة: الجدول رقم(14) يبينإن المثقف مدعو إلى التصدي لكل الأفكار الخاطئة التي تروج بضرورة التأقلم مع العولمة الراهنة

\begin{tabular}{|r|r|r|}
\hline إلإحابة & إلى حد ما \\
\hline 28,4 & 85 & نعم \\
\hline 15,7 & 47 & \\
\hline 56 & 168 & \\
\hline 100 & 300 & المجموع \\
\hline
\end{tabular}

يتضح من الجدول أعلاه بأن المثقف مدعو إلى التصدي لكل الأفكار الخاطئة التي تروج بضرورة التأقلم

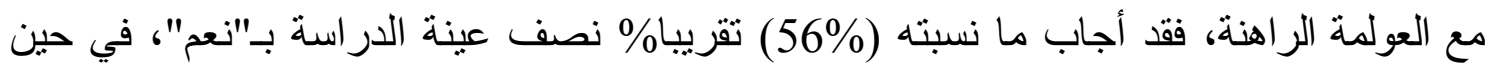

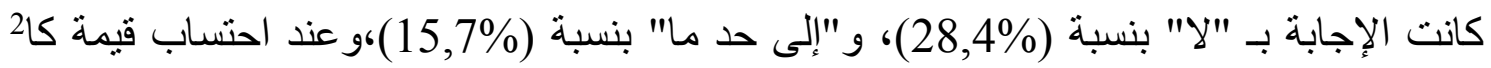

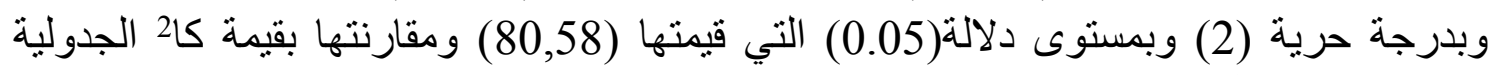
(5,991)، ومن ثَمَ فان ذلك يدل على وجود فو ارق معنوية بين إجابات المبحوثين. 14-مهمة المثقفين هي مناقثة وفصح أساليب الهيمنة التي تُمارس في جميع صيغها (الاقتصادية، و السياسية، و العسكرية، و الثقافية):

الجدول رقم(15) يبين أن مهمة المتقفين هي مناقثنة وفصح أساليب الهيمنة التي تُمارس في جميع صيغها (الاقتصادية، والسياسية، و العسكرية، والثنافية)

\begin{tabular}{|r|r|r|}
\hline$\%$ & نع الاحابة & \\
\hline 95,7 & 287 & نعم \\
\hline 4,3 & 13 & \\
\hline 100 & 300 & المجموع \\
\hline
\end{tabular}

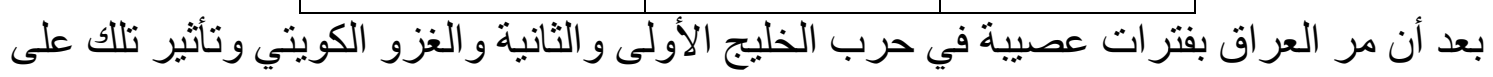

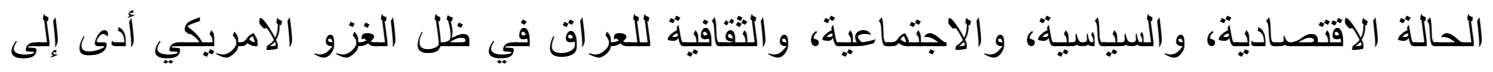

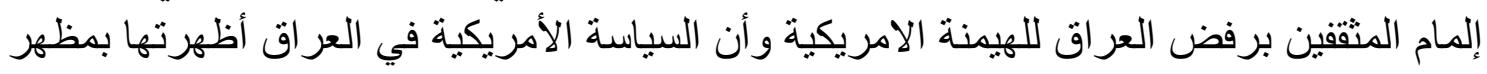


العدو المغتصب، وأن مهمة المثقفين هي مناقنة وفصح أساليب الهيمنة التي ثُمارس في جميع صيغها

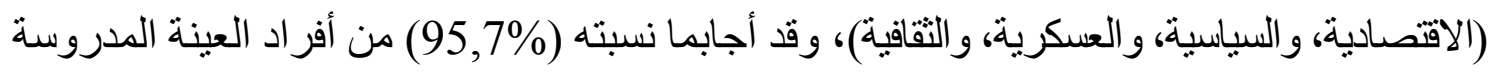

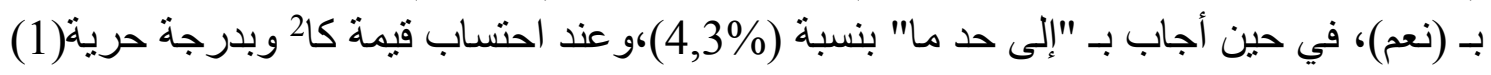

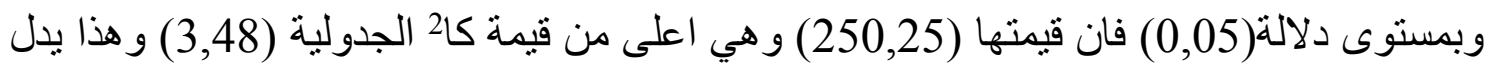
على وجود فروق معنوية بين إجابات المبحوثين.

15-إن المهمة الأساسية التي يجبأن يضطلع بهالمثقفون فيأيمجتمع هيإبراز المشكلات التي يعاني منها

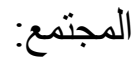

الجدول رقم(16) يبين المهمة الأساسية التي يجب أن بضطلع بها المثققون في أب مجتمع هي إيراز المشكلات التي يعاني منها المجتمع لاى عينة الدر اسة الاسة

\begin{tabular}{|c|c|c|}
\hline$\%$ & 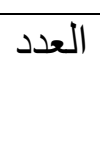 & المشكمة الأساسية التي يجب الن يضاني منها المجتمع \\
\hline 44,7 & 134 & خاصة تللك المشكلات المتعلقة بالأمن و السلم الاجتماعي \\
\hline 31 & 93 & توفير العدالة الاجتماعية \\
\hline 24,3 & 73 & مؤازرة حقوق الإنسان \\
\hline 100 & 300 & المجموع \\
\hline
\end{tabular}

إن المهمة الأساسية التي يجب أن يضطلع بها المثقون في أي مجتمع هي إبراز المشكلات التي يعاني منها

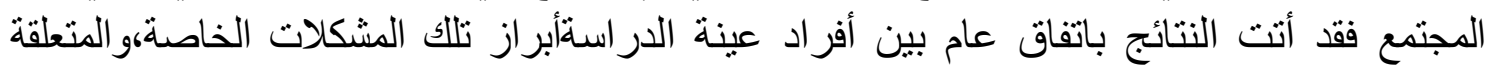

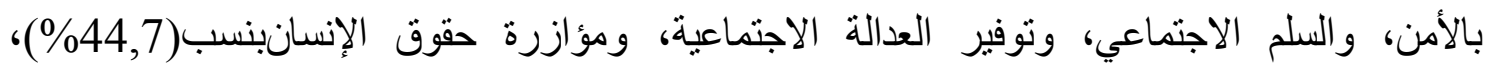

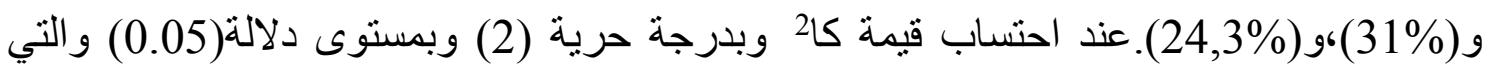

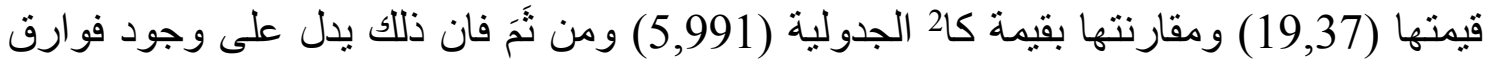
معنوية بين إجابات المبحوثين.

16-للمثقف القدرة الأدبية و المعنوية على الوقوف إلى جانب الحقوق المنزو عة والدفاع عنهاو الصمود: الجدول رقم(17) يبين إن للمثقف القدرة الأدبية والمعنوية على الوقوف إلى جانب الحقوق المنزوعة،

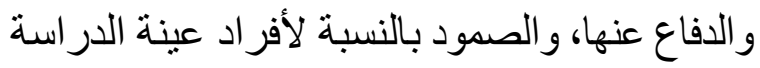

\begin{tabular}{|l|l|l|}
\hline البديل & \\
\hline
\end{tabular}




\begin{tabular}{|r|r|r|}
\hline 86,3 & 259 & نعم \\
\hline 10,7 & 32 & اللى حد ما \\
\hline 3 & 9 & المجموع \\
\hline 100 & 300 & لإ. \\
\hline
\end{tabular}

و يأتي للمثقف القدرة الأدبية والمعنوية على الوقوف إلى جانب الحقوق المنزو عة و الدفاع عنها والصمود،

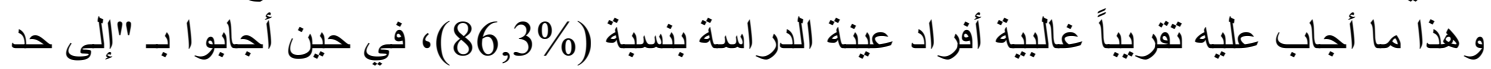

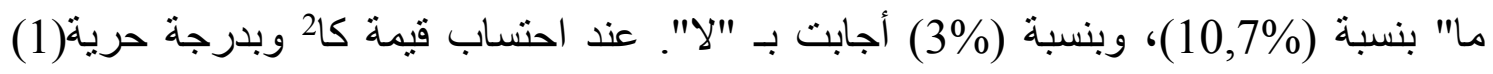

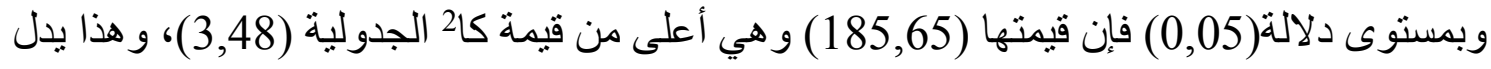
على وجود فروق معنوية بين اجابات المبحوثين.

17-يأتي دور المثقف في وجوده في المجتمع وفهمه الصحيح لمنظومة القيم، و المعتقدات للمجتمع العر اقي: الجدول رقم(18) يبين دور المنقف في وجوده في المجتمع وفهمه الصحيح لمنظومة القيم، والمعتقدات للمجتمع العر اقي

\begin{tabular}{|r|r|r|}
\hline$\%$ & العدد & \\
\hline 71,3 & 214 & الإجابة \\
\hline 28,7 & 86 & المجموع \\
\hline 100 & 300 & العم \\
\hline
\end{tabular}

في إجابات المبحوثين في الجدول رقم(18) فقد أجاب أكثر أفر اد عينة الدراسة بـ "نعم" ما نسبته

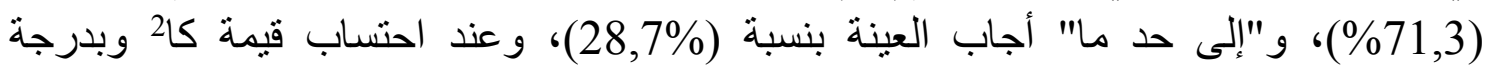

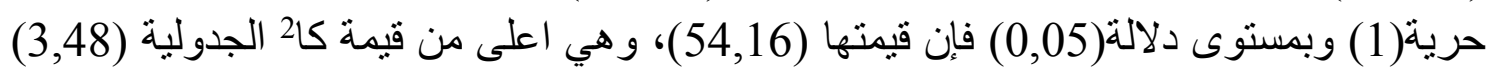
وهذا يدل على وجود فروق معنوية بين إجابات المبحوثين. النتائج و التوصيات: أو لاً: مناقشة لنتائج الدر اسة 1-إن مخاطر الهيمنة الأمريكية على البلدان العربية متنوعة الأشكال متعددة الجوانب، إذ تطمع

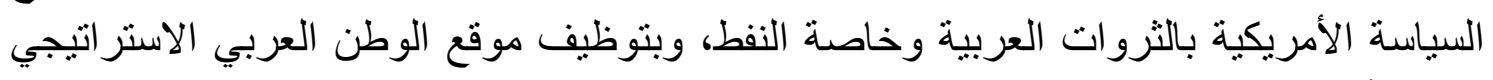
قاعدة لأهدافها الكونية. 
2-إن أهم شكل من أثنكال الهيمنة الأمريكية على العراق هي الهيمنة العسكرية، أو التدخل

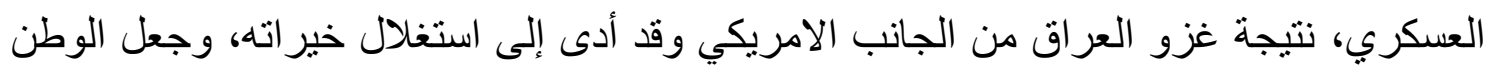
العربي قاعدة متقدمة لها في محاو لاتها للهيمنة المبانشرة العسكرية و الاقتصادية والئية والسياسية.

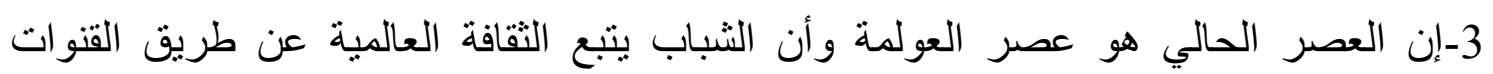

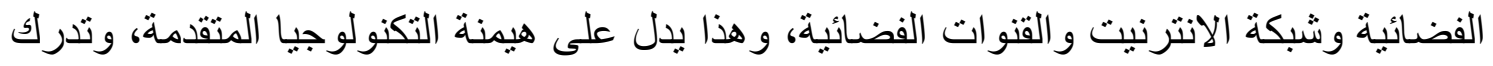

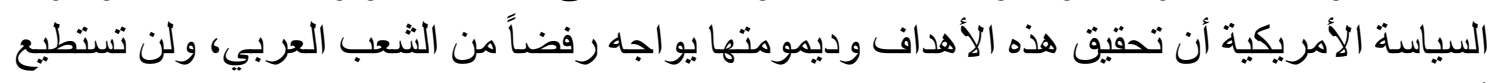

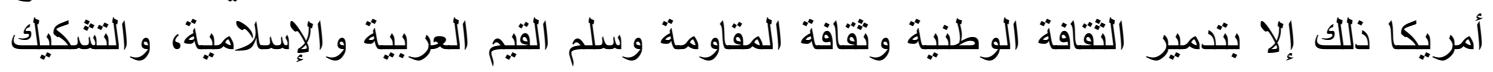

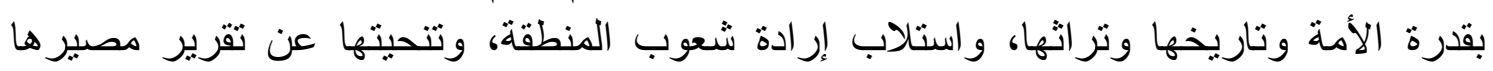

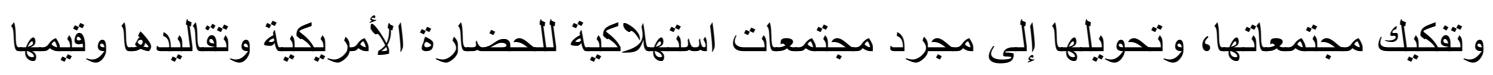

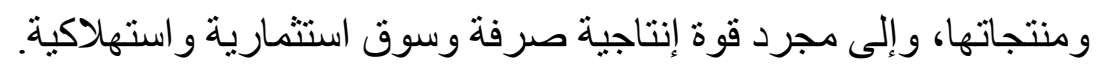

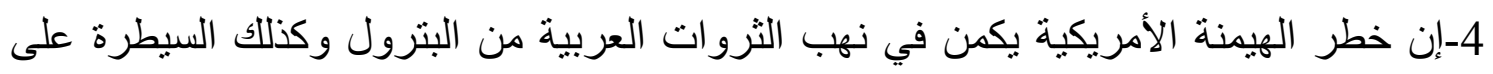

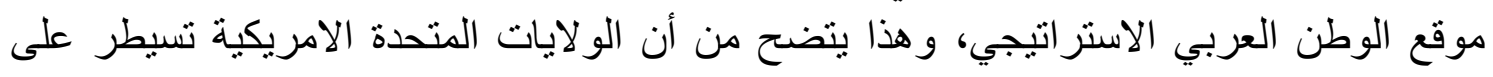

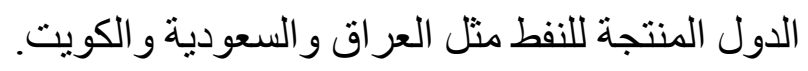

5-إن أهداف الهيمنة الأمريكية لا تتحقق إلا بالعدوان على روح الأمة العربية نفسها والتراث

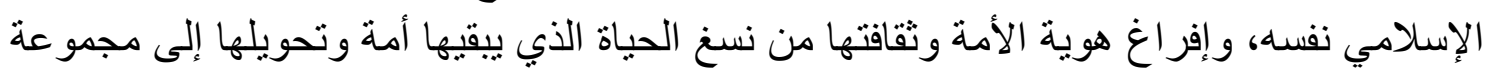

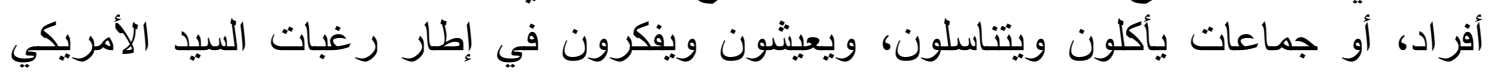
و وثقافته، وتقاليده الاستهلاكية.

6-إن الهيمنة الثقافية الأمريكية جاء فيها أن الدول العربية تتبع ثقافة القطب الواحد. ثانباً: أهم التوصيات المقترحة

1- ضرورة تعزيز العلاقات بين المثقين و السياسيين، و على المثقفين العر اقيين العمل على توحيد

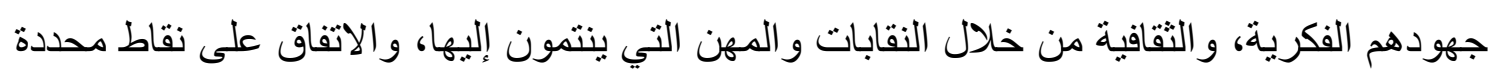
تبين بوضوح مجال نشاطهم الثقافي و السياسي.

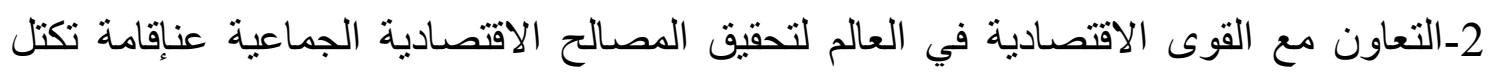

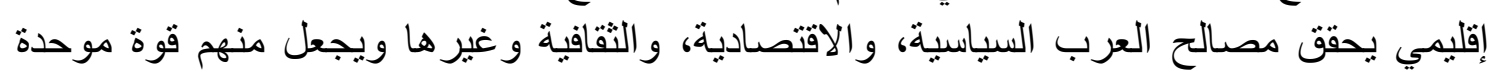
قادرة على التخاطب مع قوى العالم الأخرى من موقع القوي المقتدر.

3-فهم الظروف و المسببات التي أوصلتنا إلى الحال الذي نحن فيه الذي أشرت إلى إليه آنفاً، والعمل

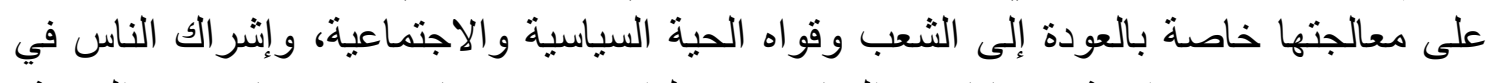

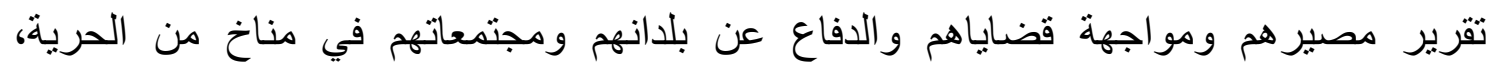


و الديموقر اطية، و الحوار تتيح لهم تنظيم أنفسهم و العمل النضالي الحر ، و المسؤول في إطار برنامج

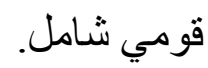

4-إن يعمل الجميع أنظمة وحكومات وأحزاباً ومؤسسات أهلية ونخب ثقافية لإقامة نظام عربي

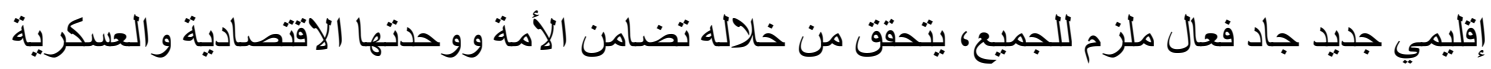

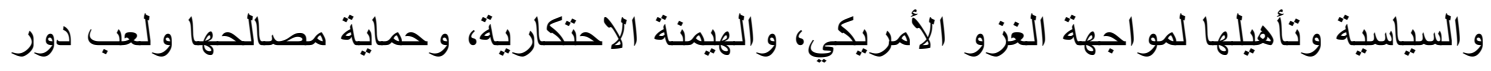
حيوي في السياسة العالمية.

5- اتباع مختلف الوسائل لزيادة الضغط الثعبي على الحكومات والأنظمة السياسية العربية ودفعها

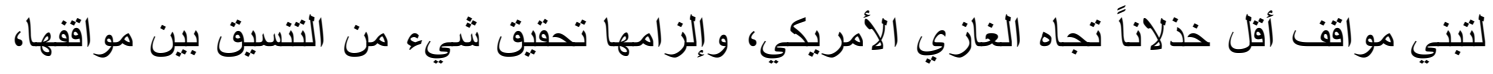

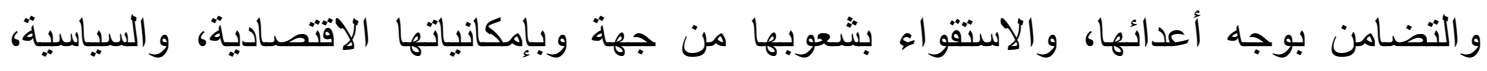

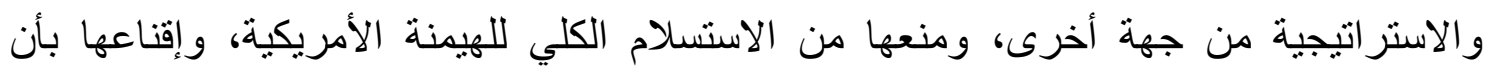

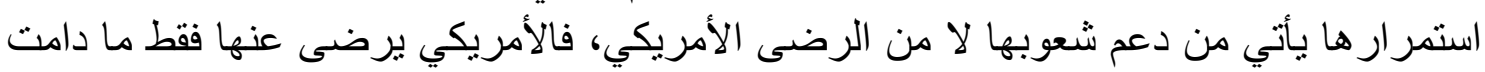

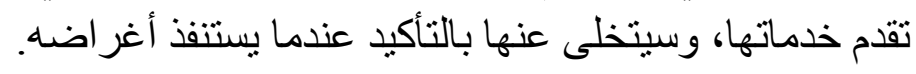

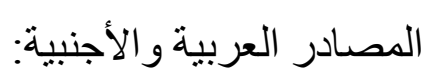

1- إبر اهيم نافع، إنفجار سبتمبر بين العولمة والأمركة، (القاهرة: الهيئة المصرية العامة للكتاب،

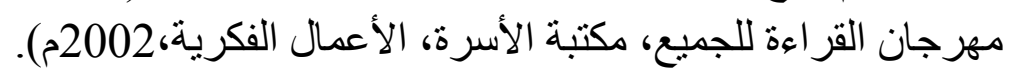

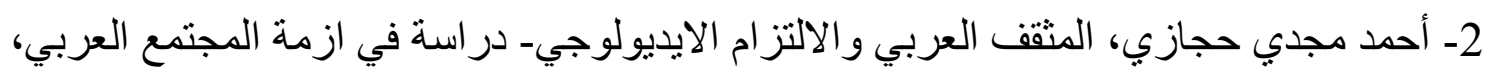

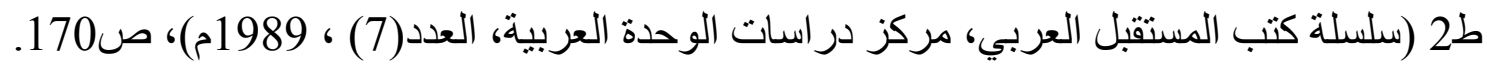
3- أنطوني كينج، النقافة والعولمة والنظام العالمي، ترجمة: شهرت العالم وآخرون، (القاهرة:

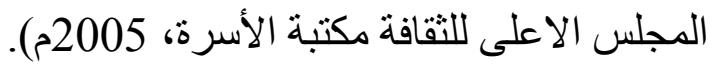

4- برهان غليون، الانتلجنسيا والسياسة والمجتمع، (بيروت: دار الاجتهاد والمجتمع، العدد

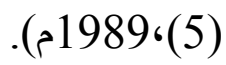

5- جيرار ليكلرك، سوسيولوجيا المثقفين، ترجمة: جورج كتوره، (بيروت لـبنان: دار الكتاب الجديد المتحدة، 2008م).

6- حسن حنفي، العولمة بين الحقيقة والوهم، في حسن حنفى، صادق العظم، ما العولمة؛؟، كتاب حوارات لقرن جديد(سورية: دار الفكر، 2002م).

7- حسين عبد الحميد رشوان، الثقافة - دراسة في علم الاجتماع الثقافي، (الاسكندرية: مؤسسة الثباب الجامعي، 2006م). 
8- حسين حموي، الخطاب الثقافي و المشهد السياسي في مواجهة الغزو الصهيوني، دمشق: دار

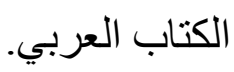

9- حمدي عبد الرحمن، العولمة وآثار ها السلبية علي النظام الإقليمي العربي: رؤية عربية، المستقبل العربي، عدد(258)، (بيروت: مركز دراسات الوحدة العربية، العبة 2000م).

10- السيد يسين، آفاق المعرفة في عصر العولمة، (القاهرة: الهيئة المصرية العامة للكتاب، (2011

11- شؤون إجتماعية، السنة (21) ، عدد(83)، (الثارقة، جمعية الإجتماعيين و الجامعة الأمريكية بالثار قة).

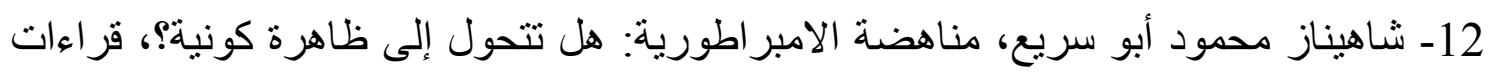

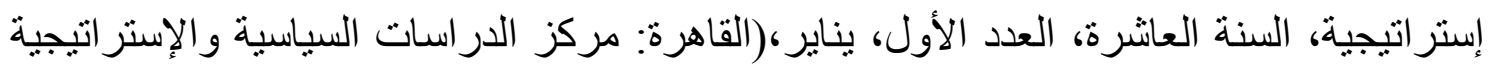
بالأهر ام، 2005 م).

13- صاحب الربيعي، الصراع بين السياسي والمثنق: قيم أم مصالح؟، الديمقراطية، السنة

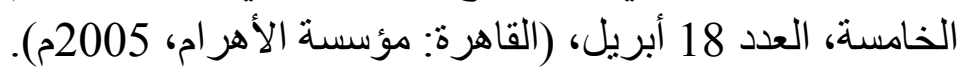

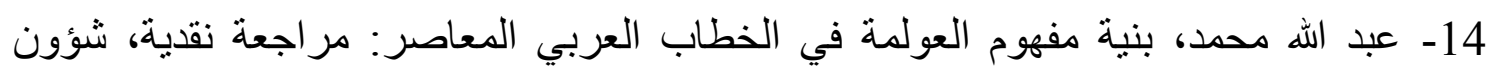
إجتماعية، السنة(21)، عدد(83)، (الثارقة، جمعية الإجتماعيين و الجامعة الأمريكية بالثارقة، .) (2004

15- عبد الخالق عبد الله، العولمة، جذورها وفروعها، وكيفية التعامل معها، الكويت، مجلة عالم الفكر، مجلد (228)، عدد(2)، 1999م).

16- عبد الله محمد، بنية مفهوم العولمة في الخطاب العربي المعاصر : مر اجعة نقدية،2004م. 17- عامر حسن فياض، الطبقة الوسطى عن كتاب تعبئة الرأي العام لحقوق الانسان، (بغداد، المركز العر اقي للتنمية والحوار الدولي، 2006م).

18- عبد الرشيد عبد الحافظ، الآثار السلبية للعولمة على الوطن العربي وسبل مواجنها، (القاهرة:

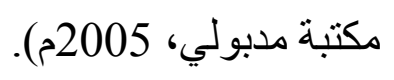

19- عبد الإله بلقزيز، 2011، العولمة والممانعة دراسات في مسألة الهوية الثقافية، (بيروت:

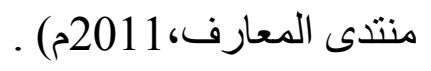


20- عبد الوهاب محمد الجبوري، اتجاهات الخطاب السياسي الأمريكي المعاصر-دراسة علمية و الدر اسات للبحوث العربي

المعرد

تحليلية، http://www.airss.net/site/2012/05/10 الإسنر اتيجية،

21- عبد المنعم الحنفي، المعجم الثامل لمصطلحات الفلسفة، (القاهرة: مكتبة مدبولي،2000م).

22- عبد السلام حيمر، في سيسيولوجيا الثقافة والمثقفين من سيسيولوجيا التمثلات إلى سيسيولوجيا الفعل الاجتماعي ومن منطق العقل إلى منطق الجسد (أو التطبع)، (بيروت: الثبكة العربية للأبحاث و النشر،2009م).

23- عزة خليل، (الحركات الاجتماعية في العالم العربي: دراسات عن الحركات الاجتماعية في

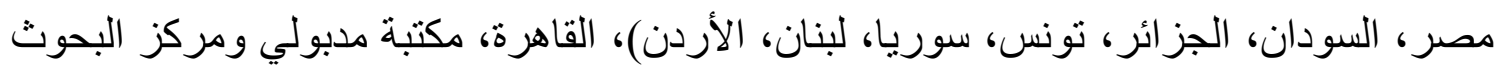

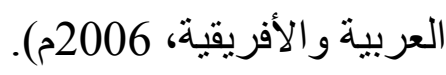

24- علي سالم، بيربورديو، اللعبة الاجتماعية، المعتقد المهيمن والمعتقد الجديد، (بيروت: كتابات

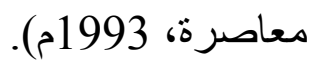
25- عو اطف عبد الرحمن، (الإعلام و العولمة البديلة)، (القاهرة، العربي للنشر والتوزيع، 2006). 26- فر غلي هارون، الإرهاب العولمي... و إنهيار الإمبر اطورية الأمريكية!! ، تقديم: سامي فريد،

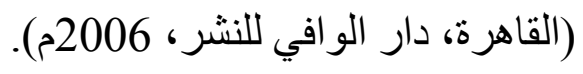

27- فريدة النقاش،2009: ثقافة المقاومة في ظل العولمة، آفاق اشتراكية، كتاب غير دوري، العدد التاسع، (القاهرة: مركز آفاق اشتر اكية، 2009: 2009م). 28- قاموس أطلس الموسو عي ( إنجليزي - عربي ) - الثركة الدولية للطباعة -2002م.

29- محمد عابد الجابري، العولمة و الهوية الثقافية، في كتاب العرب و العولمة، (بيروت، مركز

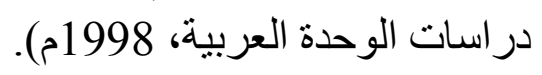
30- محمد بن مكرم بن منظور، لسان العرب ،الافريقي المصري، ج 13 ، ط1 ،(بيروت: دار

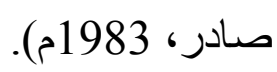

31-محمد ابر اهيم، تأملات في أزمة العقل العربي، (القاهرة: مكتبة الانجلو المصرية، 1983م). 32- محمد عبد الثفيع عيسى، العولمة والتحولات المجتمعية في الوطن العربي، مركز البحوث

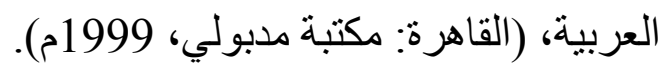


33- محمود عبد الفضيل، مصر ورياح العولمة، كتاب الهلال، عدد (585)، (القاهرة، دار الهلال،

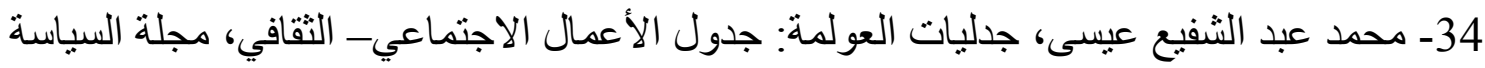

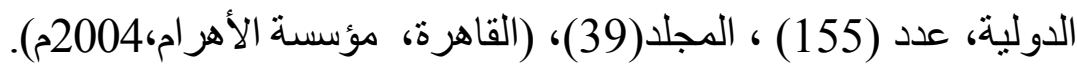

35- محمد نصر مهنا، العلاقات الدولية بين العولمة والأمركة، (الإسكندرية، المكتب الجامعي

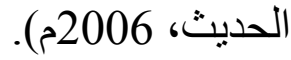

36- هارولد شومان، هانز بيترمارتين، فخ العولمة، ترجمة عدنان عباس، (الكويت، سلسلة عالم

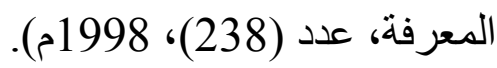

37- A.Giddens, The consequences of modernity. polity Press, cambridge, 1990.

38- E.O.Wright : Class, Crisis and the State, Verso, London, Third Published, 1993.

39-Gramsci, selections from prison notebooks, London.

46-R .G .Murdick, J. E. Ross, 1975, Information System for Modern.

40-Gerard Ignasse et Marc-Antoine Genissel, Introduction a la sociology , universities (Paris : Ellipses,1995) .

41-J. Asimpson \& Eseweiner, The Oxford Dictionary, London, 1991.

42-Kobrin, Stephen. "Our Resistance is as global as your oppression": multinational corporations, the protest movement and the future of global governance, U.S.A, Philadelphia, university of Pennsylvania, Department of Management, 2001.Management, 2th ed. New Jersey: Prentice Hall.

43- Smith, Infernal Machines, book review in English, Arab Journal for humanities, no. (79/20), 1998. 